UNIVERSIDADE DE SÃO PAULO

ESCOLA DE ENGENHARIA DE SÃO CARLOS

DEPARTAMENTO DE GEOTECNIA

\title{
PROVA DE CARGA RÁPIDA COM RECALQUE ESTABILIZADO
}

\author{
MARINA PREARO BENVENUTTI ALMEIDA
}

Dissertação apresentada à Escola de Engenharia de São Carlos da Universidade de São Paulo, Programa de Pósgraduação em Geotecnia, como parte dos requisitos para a obtenção do título de Mestre em Ciências.

ORIENTADOR: PROF. DR. JOSÉ CARLOS ANGELO CINTRA

SÃO CARLOS - SP 

Candidata: Engenteira MARINA PREARO BENVENUTTI ALMEIDA,

Dissertaçio delendida e julgada em 25/06/2009 perante a Comissăo Julgadora:

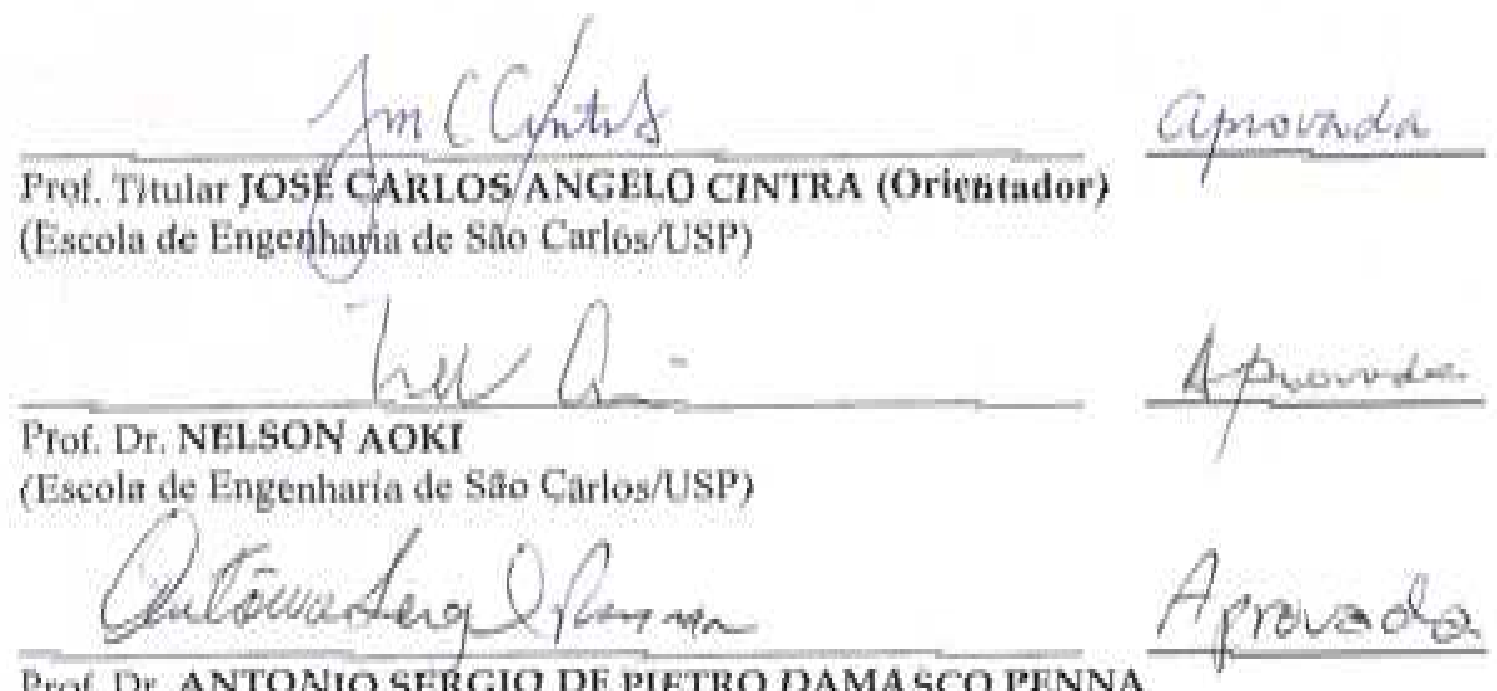

PIOL, DI. ANTONIO SERGIO DE PIETRO DAMASCO PENNA

(Universidado Presbiteriana Mhekenzic/UPM)

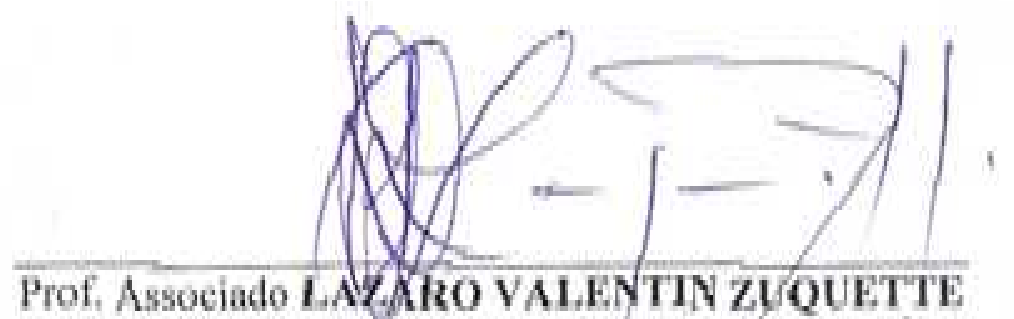

Coordenador do Programa de Pbl-Gradinçấo em

Gootecniti

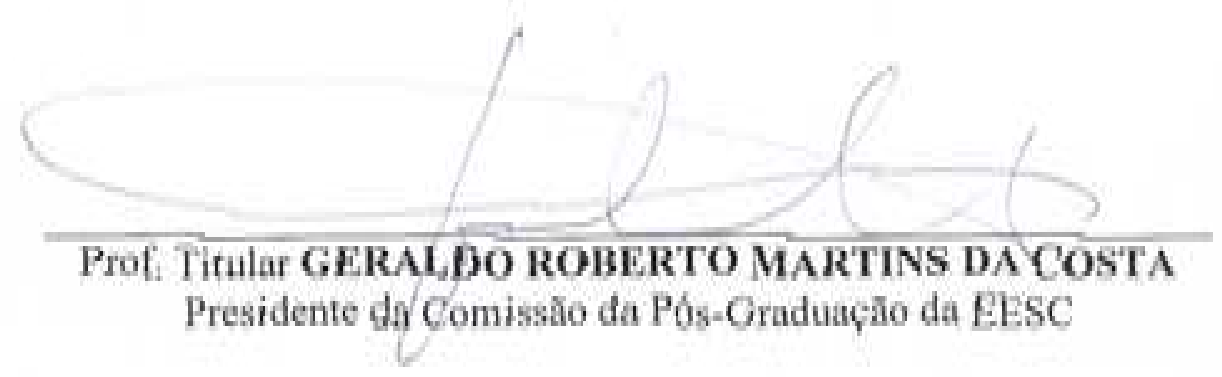



Dedico este trabalho às pessoas mais importantes da minha vida: meus pais, Márcio e Beatriz, meus exemplos de vida, meus irmãos, Netto e Marcelo, e o Aurélio, meu marido amado. 



\section{AGRADECIMENTOS}

Primeiramente, gostaria de agradecer a DEUS por ter me dado o DOM da vida, e nesta importante etapa ter provido saúde, proteção e força para cumprir todos os objetivos.

Ao meu orientador, Prof. Dr. JOSÉ CARLOS CINTRA, de quem orgulho-me em dizer que fui aluna. Agradeço pela enorme oportunidade, orientação, paciência e amizade. Seus ensinamentos foram fundamentais para que eu realizasse um grande sonho. Obrigada por compartilhar os seus valiosos conhecimentos em Geotecnia e Técnicas de Apresentação!

Ao professor Prof. Dr. NELSON AOKI, que possui humildade, entusiasmo e conhecimento excepcional. Obrigada pelo carinho e por tudo que me ensinou!

Agradeço aos meus queridos pais, MÁRCIO E BIA, por todo o amor, carinho e atenção e por me incentivar sempre a lutar, sem nunca desanimar, por maiores que sejam as dificuldades. Muito obrigada pelo exemplo de vida. Amo muito vocês!

Ao meu marido, AURÉLIO, pelo amor, pela compreensão e carinhos incondicionais que sempre me dedicou. Obrigada por me fazer a pessoa mais feliz do mundo "tipo assim, da China"! Te amo muito.

Aos meus irmãos, NETTO E MARCELO, pelo convívio em amor, que faz de nós uma família unida e feliz. Vocês são e sempre serão os meus "brothers". Amo demais vocês!

Aos meus avós, MARINA, OSCAR E OLGA, que são exemplos de sabedoria. Amo vocês.

Aos meus sogros, RACHEL E JOALDOMAR, pela atenção, carinho e incentivo. Vocês moram no meu coração! 

Aos amigos especiais como, LEONARDO, RODRIGO, LíCIA, DANILO, TARSILA, LÍDIO, A BIO, GISLAINE E BRUNA, pela alegria, pelo carinho e descontração sempre presentes. É bom conviver com pessoas como vocês!

Em especial a minha grande amiga, JULIANA, que hoje tenho como mais que amiga, uma irmã. JÚ, você e a MARIELI sempre me acolheram como uma família e nunca terei como retribuir tanta generosidade e amor. Vocês estarão guardadas para sempre em meu coração.

Aos professores do departamento de Geotecnia da Escola de Engenharia de São Carlos, que muito contribuíram para meu crescimento e aprendizado. Em especial aos Professores Antônio Airton Bortolucci e Tarcisio Barreto Celestino, que foram generosos ao disponibilizar a Prensa MTS-815 - Rock Mechanics Testing System do Laboratório de Mecânica das Rochas.

Aos funcionários do Departamento de Geotecnia da Escola de Engenharia de São Carlos, em especial a Maristela, Neiva e Álvaro.

Aos técnicos do Laboratório, muito obrigada pelo enorme carinho, atenção e preocupação que sempre tiveram comigo. Obrigada em especial ao DITO, ZÉ E OSCAR.

Aos colegas da geotecnia que tornaram estes momentos felizes, dos quais ficarei com saudades: LUCIENE, VAL, CRISLEY, SIMONE, IVAN, FAGNER, VAGNER, JÚLIO FIALHO, JÚLIO ZAMBRANO, KARLA E VANESSA.

A empresa MB PERFIL DE FUNDAÇÕES LTDA, pelo apoio financeiro. 



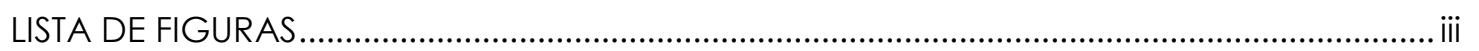

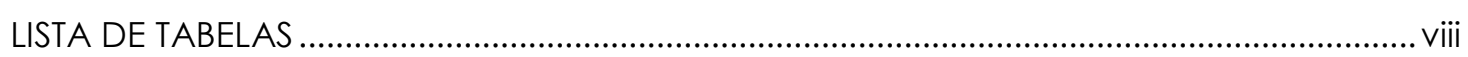

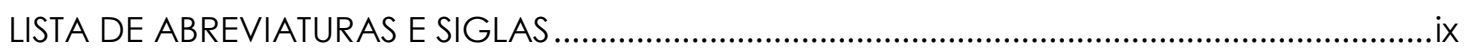

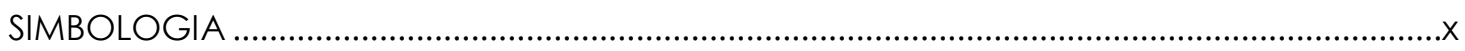

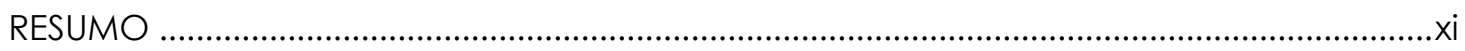

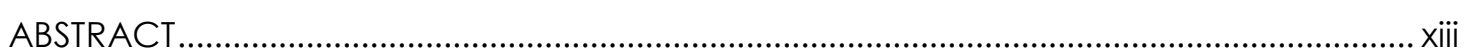

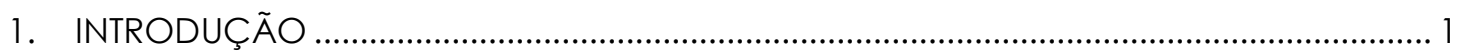

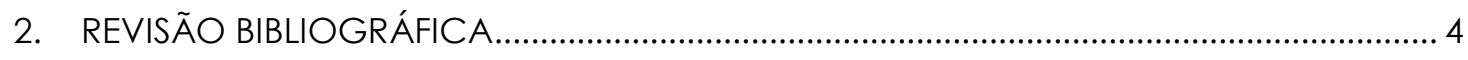

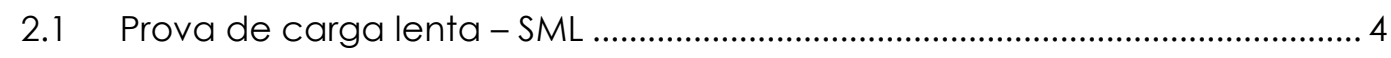

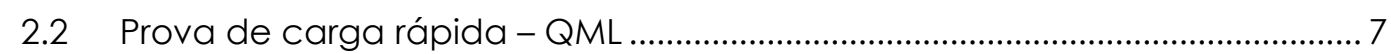

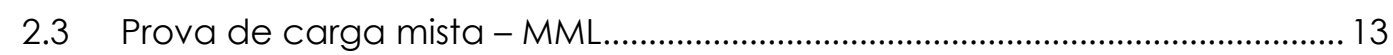

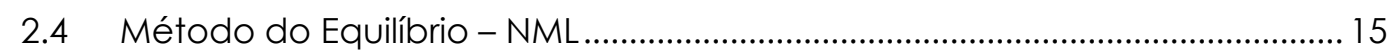

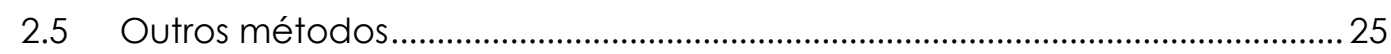

2.5.1 Método de deformação controlada - CRP ......................................................... 25

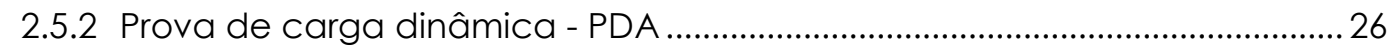

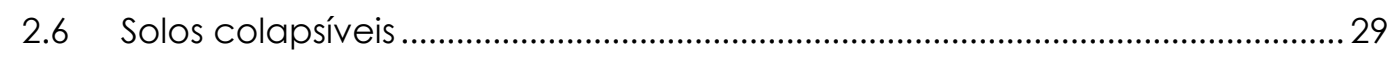

2.7 Influência da sucção na capacidade de carga ..............................................29

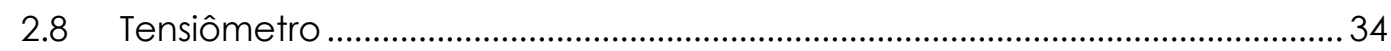

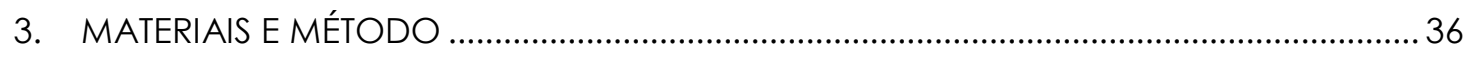

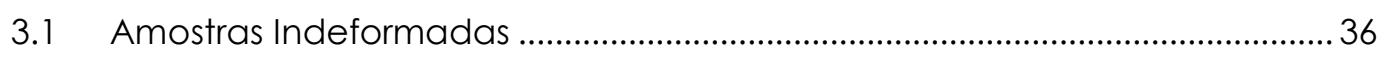

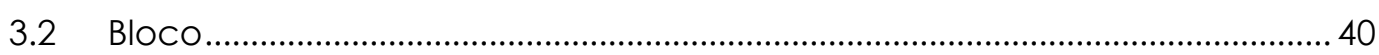

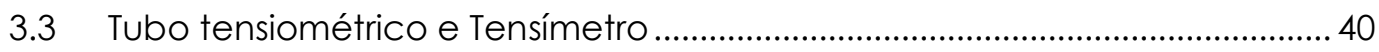

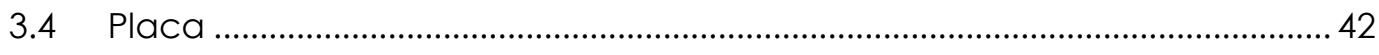

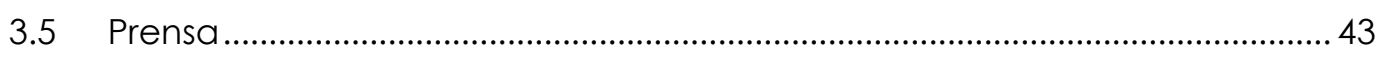

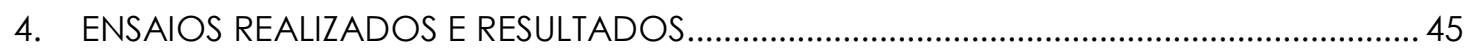

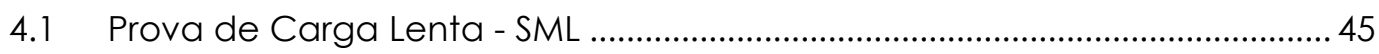


4.2 Prova de Carga Rápida - QML ............................................................................. 47

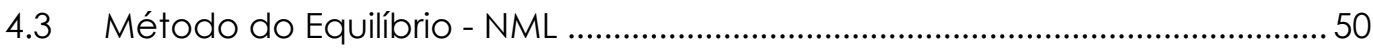

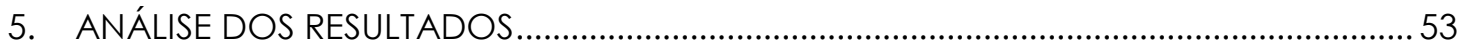

5.1 Curva tensão x recalque para o Método do Equilíbrio - NML ........................53

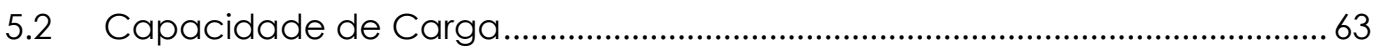

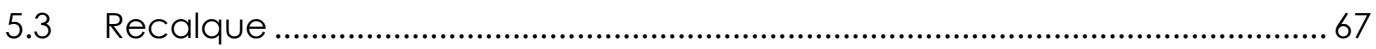

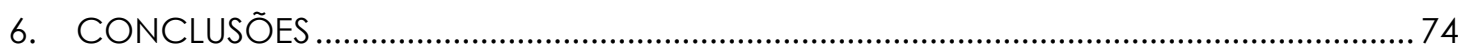

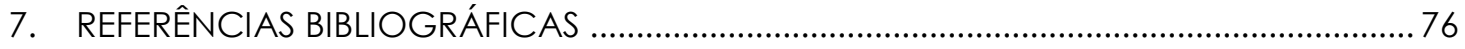




\section{LISTA DE FIGURAS}

Figura 1. 1- Prova de carga QML e SML. 2

Figura 2. 1- Gráficos tensão x recalque das provas de carga de 1 a 4 (Adaptado de IPT,

Figura 2.2- Gráficos tensão x recalque das provas de carga de 3 a 6 (Adaptado de IPT, 1944)

6

Figura 2.3- Gráficos tensão x recalque em profundidades diferente (Adaptado de IPT, 1954) 7

Figura 2.4- Curvas tensão x recalque dos ensaios SML inundados (COSTA, 1999) ........................ 8

Figura 2.5- Curvas tensão x recalque dos ensaios QML inundados (COSTA, 1999) ....................... 8

Figura 2.6- Curvas tensão $x$ recalque para os ensaios inundados (COSTA, 1999) ........................ 9

Figura 2.7- Curva tensão x recalque para a profundidade de 1,5 m (33 kPa) (MACACARI,

2001) 10

Figura 2.8- Curvas tensão x recalque para a profundidade de 4,0 m (MACACARI, 2001) ....... 10

Figura 2.9- Curvas tensão x recalque para a profundidade de 6,0 m (MACACARI, 2001) ....... 10

Figura 2.10- Curvas tensão x recalque para a profundidade de 8,0 m (MACACARI, 2001)..... 11

Figura 2.1 1- Curvas tensão x recalque dos ensaios para a placa de 0,20 m (VIANNA, 2005) . 11

Figura 2. 12 - Curvas tensão x recalque dos ensaios para a placa de 0,40 m (VIANNA, 2005) 12

Figura 2.13 - Curvas tensão x recalque dos ensaios para a placa de 1,50 m (VIANNA, 2005) 12

Figura 2.14 - Capacidade de carga x diâmetro da placa ou sapata, ensaios inundados

(VIANNA, 2005) 13

Figura 2.15 - Curvas tensão x recalque dos ensaios MML, inundados (COSTA, 1999) ............... 14

Figura 2.16 - Curvas tensão x recalque dos ensaios inundados das diversas modalidades .... 14

Figura 2.17 - Curva carga $x$ recalque da estaca 1 (MOHAN et al., 1967) ...................................... 16

Figura 2.18 - Curva carga $x$ recalque da estaca 2 (MOHAN et al., 1967) ................................... 16

Figura 2.19 - Curva carga $x$ recalque da estaca 3 (MOHAN et al., 1967) .................................... 17

Figura 2.20 - Curva carga $x$ recalque da estaca 4 (MOHAN et al., 1967) .................................... 18

Figura 2. 21 - Gráfico carga x recalque para a estaca PV-2 (modificado de FERREIRA, 1985) 20 
Figura 2.22 - Curva carga $\times$ recalque para a estaca PV-3 (modificado de FERREIRA, 1985) ... 20

Figura 2.23 - Curva carga x recalque - QML ( FRANCISCO, 2004) ............................................... 21

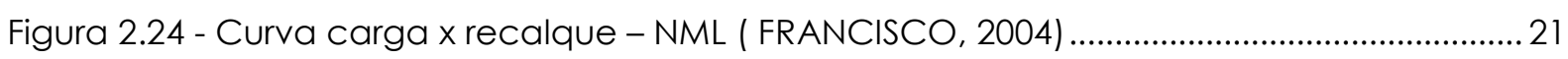

Figura 2.25 - Variação do recalque com o tempo em um estágio (FRANCISCO, 2004) ............ 22

Figura 2.26 - Variação da carga com o tempo em um estágio (FRANCISCO, 2004) ................. 22

Figura 2.27 - Resultado da prova de carga do Tubulão 1, com o solo não inundado

( BENVENUTTI, 2001) .23

Figura 2.28 - Resultado da prova de carga do Tubulão 2, com o solo previamente inundado (BENVENUTTI, 2001) .24

Figura 2.29 - Curvas tensão x recalque típicas dos diferentes tipos de ensaio (FELLENIUS, 1975)

Figura 2. 30- Curvas tensão x recalque de três ensaios consecutivos: um dinâmico entre dois estáticos (cava 9, terreno não inundado) (MORAES, 2005)

Figura 2. 31- Curvas $x$ tensão recalque de três ensaios consecutivos: um dinâmico entre dois estáticos (cava 4, terreno não inundado) (MORAES, 2005)

Figura 2. 32- Curvas $x$ tensão recalque de três ensaios consecutivos: um dinâmico entre dois estáticos (cava 7, terreno inundado) (MORAES, 2005) .

Figura 2. 33- Curvas tensão x recalque de três ensaios consecutivos: um dinâmico entre dois estáticos (cava 8, terreno inundado) (MORAES, 2005) 28

Figura 2.34 - Variação da capacidade de carga de sapatas corridas em função da sucção matricial (FREDLUND \& RAHARDJO, 1993)

Figura 2.35 - Curva tensão x recalque dos ensaios SML realizados em diferentes níveis de sucção (Costa, 1999) 30

Figura 2.36 - Curva tensão x recalque dos ensaios SML realizados em diferentes níveis de sucção

Figura 2.37 - Variação das curvas previstas de tensão x recalque com a sucção para ensaios de placa do tipo lento e rápido à 1,5 m de profundidade (MENEGOTTO, 2004) ...... .32

Figura 2.38 - Variação da capacidade de carga com a sucção (MENEGOTTO, 2004) ...... 32 
Figura 2.39 - Curvas de tensão x recalque dos ensaios para placa de 0,20 m (VIANNA, 2004)

Figura 2.40 - Família de curvas carga recalque para diferentes valores de sucção matricial média no solo (CINTRA, 2004) 33

Figura 2. 41 - Tipos mais comuns de tensiômetro: de coluna de mercúrio (A), com vacuômetro (B) e com transdutor de pressão ou tensímetro (C) (Serviço Brasileiro de Respostas Técnicas - SBRT). 34

Figura 3. 1 - Curva granulométrica do solo ensaiado (modificado de SOTO, 2004) 37

Figura 3.2 - Curvas de retenção obtidas por diferentes métodos para o solo estudado (SOTO, 2004) 37

Figura 3.3 - Imagens do solo estudado provenientes da microscopia eletrônica de varredura

a) aproximação de 275 vezes; b) aproximação de 300 vezes (SOTO, 2004) 38

Figura 3.4 - (a) esquema de montagem da caixa (b) retirada das amostras no campo .........38

Figura 3. 5 - Amostra colocada sobre chapa metálica e chapa de madeira 39

Figura 3.6- Bloco sendo envolvido em tecido poroso. 39

Figura 3.7 -Bloco armazenado em câmara úmida 40

Figura 3.8 - Tubo tensiométrico. 41

Figura 3.9 - Tensímetro 41

Figura 3.10- Tubos tensiométricos instalados no bloco. 42

Figura 3.1 1- Vista da placa de 40 mm com "aba". 42

Figura 3.12 - Esquema da placa vista superior e vista lateral 43

Figura 3.13 - Vista geral da prensa 43

Figura 3.14 - Bloco com os relógios comparadores. 44

Figura 3.15 - Sistema de aquisição de dados. 44

Figura4. 1- Curvas tensão $\times$ recalque dos ensaios SML ( $\psi \mathrm{m} \cong 0) \quad 45$

Figura4. 2 - Curvas tensão $\times$ recalque dos ensaios SML $(\psi \mathrm{m}=10 \mathrm{kPa})$ .46

Figura4. 3 - Curva tensão $x$ recalque do ensaios SML $(\psi m=35 \mathrm{kPa})$ 46

Figura4. 4- Curvas tensão $\times$ recalque dos ensaios SML $(\psi \mathrm{m}=45 \mathrm{kPa})$ .47 


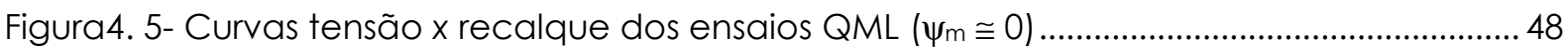

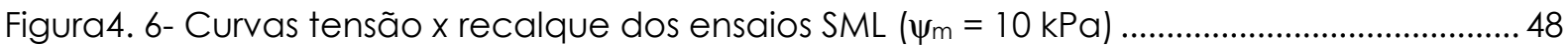

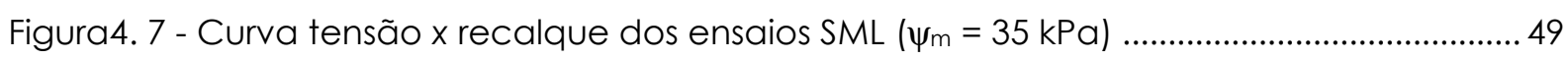

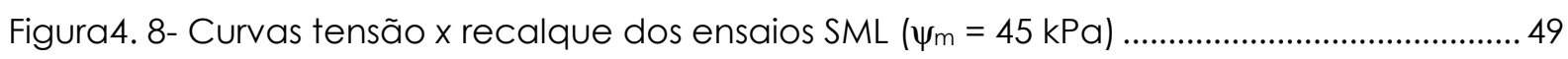

Figura4. 9 - Curvas tensão $x$ recalque dos ensaios NML $(\psi m \cong 0)$

Figura4. 10- Curvas tensão $x$ recalque dos ensaios $\mathrm{NML}\left(\psi_{\mathrm{m}} \cong 10 \mathrm{kPa}\right)$.........................................51

Figura4. 11- Curva tensão $x$ recalque dos ensaios NML $\left(\psi_{m}=35 \mathrm{kPa}\right)$........................................52

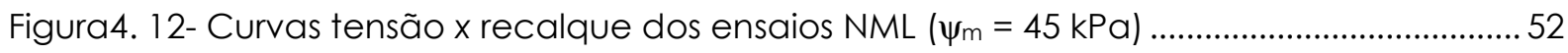

Figura 5. 1-Variação do recalque com o tempo no estágio com tensão inicial de 240 kPa

$$
\left(\psi_{\mathrm{m}}=45 \mathrm{kPa}\right)
$$

Figura 5. 2- Variação da tensão com o tempo no estágio com tensão inicial de $240 \mathrm{kPa}(\psi \mathrm{m}$ $=45 \mathrm{kPa})$

Figura 5. 3- Curva de ajuste utilizada para determinar o valor da tensão estabilizada

(Programa Table Curve) 55

Figura 5. 4- Curvas de ajuste utilizadas para determinar o valor da tensão estabilizada ........55

Figura 5. 5- Curva tensão x recalque obtida pelo método do equilíbrio (Bloco $106-\psi \mathrm{m} \cong 0$ ) 56

Figura 5. 6- Curva tensão x recalque obtida pelo método do equilíbrio (Bloco $304-\psi \mathrm{m} \cong 0$ ) 57

Figura 5. 7- Curva tensão x recalque obtida pelo método do equilíbrio (Bloco $308-\psi \mathrm{m} \cong 0$ ) 57

Figura 5. 8- Curva tensão x recalque obtida pelo método do equilíbrio (Bloco $403-\psi_{\mathrm{m}}=10$

$\mathrm{kPa})$

Figura 5. 9- Curva tensão x recalque obtida pelo método do equilíbrio (Bloco $405-\psi \mathrm{m}=10$

$\mathrm{kPa})$

Figura 5. 10- Curva tensão x recalque obtida pelo método do equilíbrio (Bloco $110-\psi \mathrm{m}=35$

$\mathrm{kPa})$

Figura 5. 11-Curva tensão $\times$ recalque obtida pelo método do equilíbrio (Bloco $202-\psi_{\mathrm{m}}=45$

$\mathrm{kPa})$

Figura 5. 12- Curva tensão x recalque obtida pelo método do equilíbrio (Bloco $206-\psi \mathrm{m}=45$

$\mathrm{kPa}$ ) 
Figura 5. 13-Curvas tensão x recalque obtidas através nas de carga lenta, rápida e método do Equilíbrio $\left(\psi_{m} \cong 0\right)$.

Figura 5. 14-Curvas tensão x recalque obtidas através nas de carga lenta, rápida e

Figura 5. 15- Curvas tensão x recalque obtidas nas provas de carga lenta, rápida e 62

Figura 5. 16-Curvas tensão x recalque obtidas nas provas de carga lenta, rápida e método do Equilíbrio $\left(\psi_{\mathrm{m}}=45 \mathrm{kPa}\right)$.

Figura 5. 17- Capacidade de carga em função da sucção e do tipo de ensaio, e variação percentual de or em relação do SML .65

Figura 5. 18 - Variação da capacidade de carga com a sucção matricial ...... .66

Figura 5. 19- Recalque em função da capacidade de carga e do tipo de ensaio, e variação percentual de recalque em relação do SML $\left(\psi_{m} \cong 0 \mathrm{kPa}\right)$ .69

Figura 5. 20- Recalque em função da capacidade de carga e do tipo de ensaio, e variação percentual de recalque em relação do SML $(\psi \mathrm{m}=10 \mathrm{kPa})$ .70

Figura 5. 21- Recalque em função da capacidade de carga e do tipo de ensaio, e variação percentual de recalque em relação do SML $\left(\psi_{m}=35\right)$

Figura 5. 22- Recalque em função da capacidade de carga e do tipo de ensaio, e variação percentual de recalque em relação do SML $\left(\psi_{m}=45\right)$ 72 
Tabela 2. 1- Recalque para carga admissível de 2500 kN (FERREIRA, 1985) 19

Tabela 3. 1- Resultados de caracterização e compactação do solo (SOTO, 2004) 36

Tabela 5. 1-Valores de capacidade de carga obtidos pelo critério de ruptura convencional de TERZAGHI (1942) $-\psi_{m} \cong 0$ 63

Tabela 5. 2- Valores de capacidade de carga obtidos pelo critério de ruptura convencional de TERZAGHI (1942) $-\psi_{\mathrm{m}}=10 \mathrm{kPa}$ 64

Tabela 5. 3- Valores de capacidade de carga obtidos pelo critério de ruptura convencional de TERZAGHI (1942) $-\psi_{\mathrm{m}}=35 \mathrm{kPa}$ .64

Tabela 5. 4 - Valores de capacidade de carga obtidos pelo critério de ruptura convencional de TERZAGHI (1942) $-\psi_{\mathrm{m}}=45 \mathrm{kPa}$ 64

Tabela 5.5 - Valores de recalque para cinco níveis de tensão ( $\left.\psi_{\mathrm{m}} \cong 0 \mathrm{kPa}\right)$ 67

Tabela 5. 6 - Valores de recalque para cinco níveis de tensão $\left(\psi_{\mathrm{m}}=10 \mathrm{kPa}\right)$ 67

Tabela 5.7 - Valores de recalque para cinco níveis de tensão $\left(\psi_{\mathrm{m}}=35 \mathrm{kPa}\right)$ .68

Tabela 5.8 - Valores de recalque para cinco níveis de tensão $(\psi \mathrm{m}=45 \mathrm{kPa})$ 68

Tabela 5.9 - Valores médios de recalque para cinco níveis de tensão ( $\psi \mathrm{m} \cong 0 \mathrm{kPa})$ 69

Tabela 5. 10 - Valores médios de recalque para cinco níveis de tensão $\left(\psi_{\mathrm{m}}=10 \mathrm{kPa}\right) \ldots . . . . . .70$

Tabela 5. 11 - Valores de médios recalque para cinco níveis de tensão $\left(\psi_{m}=35\right) \ldots \ldots \ldots \ldots \ldots \ldots . . .71$

Tabela 5. 12 - Valores médios de recalque para cinco níveis de tensão $\left(\psi_{m}=45\right)$ .72 


\begin{tabular}{ll} 
ABNT & Associação Brasileira de Normas Técnicas \\
CRP & Constant Rate of Penetration Test \\
DERSA & Desenvolvimento Rodoviário de São Paulo S.A. \\
EESC & Escola de Engenharia de São Carlos \\
FPP & Funil de Placa Porosa \\
IPT & Instituto de Pesquisas Tecnológicas \\
MML & Mixed Maintained Load \\
MTS & Mechanics Testing System \\
NBR & Norma Brasileira \\
NML & No-Maintained Load \\
PDA & Prova de Carga Dinâmica \\
PF & Papel Filtro \\
QML & Quick Maintained Load \\
SML & Slow Maintained Load \\
SP & São Paulo \\
TAC & Tensiômetro de Alta Capacidade \\
TDR & Time-Domain Reflectometer \\
TE & Translação de Eixos \\
USP & Universidade de São Carlos \\
\hline
\end{tabular}




$\begin{array}{ll}\dagger & \text { Tempo } \\ \rho & \text { Recalque } \\ \psi_{m} & \text { Sucção Matricial } \\ \sigma_{r} & \text { Capacidade de carga }\end{array}$


Almeida, M. P. B. Prova de carga rápida com recalque estabilizado. 2009. 79 p. Dissertação de mestrado - Escola de Engenharia de São Carlos, Universidade de São Paulo, São Carlos, 2009.

A prova de carga estática lenta é tradicional na engenharia de fundações, no mundo todo. Mas sua realização pode envolver um tempo excessivo e, por isso, tem havido tentativas para reduzir sua duração. O ensaio rápido, ao contrário, é realizado em apenas algumas horas, mas, sem dúvida alguma, os recalques obtidos nesse ensaio são bem inferiores aos do ensaio lento.

Uma alternativa promissora pode ser o ensaio pelo método do equilíbrio, que parece reunir as vantagens daquelas duas modalidades. Nesse método, utiliza-se a carga mantida apenas no início do estágio e, depois, deixa-se a carga diminuir livremente até atingir uma condição de equilíbrio, com recalque e carga estabilizados, em cada estágio.

Neste trabalho, são apresentadas comparações entre as três modalidades, em ensaios de placa, em modelo, em solo arenoso colapsível, em duas condições: inundado e não-inundado.

PALAVRAS-CHAVE: Prova de carga, Capacidade de carga, Método do Equilíbrio, Recalque, Ensaio de placa, Solo Colapsível. 
Almeida, M. P. B. Stabilized settlements by quick maintained load test. 2009. 79 p. Master thesis - School of Engineering at São Carlos, University of São Paulo, São Carlos, 2009.

The Slow Mantained Load is a tradicional test in foundations engeneering worldwide. Nevertheless, its implementation may take too long, so there have been attempts to reduce its duration. The Quick Mantained Load Test, in other hand, takes only a few hours to be accomplished and the obtained settlements are lower than the Slow Maintained Load Test.

The Method of Equilibrium is an attractive option. It seems to combine the advantages of these two methods, using maintained load at the beginning of the stage and then allowing to freely decrease the load to reach its equilibrium.

This study compares these three methods in two conditions: non-flooded and flooded colapsive sandy-soil model.

KEYWORDS: Load test, Bearing capacity, Method of Equilibrium, Settlements, Plate load test, Colapsive soil. 



\section{INTRODUÇÃO}

A prova de carga lenta é tradicional na engenharia de fundações, no mundo todo, tanto na verificação da capacidade de carga como dos recalques, sobretudo os recalques correspondentes à carga admissível. Mas sua realização pode envolver um tempo excessivo e, por isso, tem havido tentativas para reduzir sua duração. O ensaio rápido, ao contrário, é realizado em apenas algumas horas, mas, sem dúvida alguma, os recalques obtidos nesse ensaio são bem inferiores aos do ensaio lento.

Nas últimas décadas tem havido várias tentativas, mais ou menos eficientes, para se encurtar a duração da prova de carga. Provavelmente a primeira tentativa de redução da duração do ensaio tenha sido a própria proposição do ensaio rápido (HOUSEL, 1966), pela qual a prova de carga seria realizada em oito estágios de carga com duração exata de ih cada, tendo havido ou não a estabilização de recalques, para que o ensaio pudesse ser realizado dentro de um dia de trabalho.

Fellenius (1975) defende o ensaio rápido, porém com a proposição de 20 estágios de 15 min (com leituras de recalque a cada $3 \mathrm{~min}$ ), levando a uma duração total do carregamento de 5 horas. Posteriormente, Fellenius (1980) considerou que no ensaio rápido "a duração de cada estágio é menos importante, seja 1 h ou 15 min; é o fato de que duração seja a mesma que é importante". E recomendou "intervalos de tempo constantes de 5, 10 ou 15 min". "Para ensaios corriqueiros, em que apenas a carga e o recalque da cabeça da estaca são monitorados, intervalos de tempo de 5 min são aceitáveis". "Quando estacas instrumentadas são ensaiadas, o intervalo de tempo pode ser aumentado, contudo, não é necessário ir além de 15 min". O autor conclui que, "Os ensaios QML são superiores aos SML dos pontos de vista técnico, prático e econômico". Contudo, há relutância justificada pelos ensaios rápidos, porque os recalques neles obtidos são bem inferiores aos dos lentos, conforme ilustrado pela Figura 1.1. Por isso, o ensaio rápido tem sido descartado em qualquer análise de recalques de fundações. 
Prova de carga rápida com recalque estabilizado

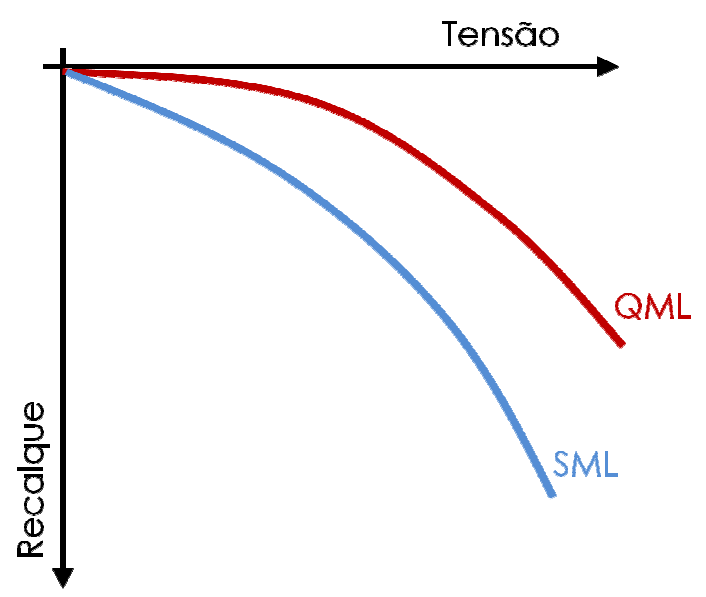

Figura 1. 1- Prova de carga QML e SML

Uma sugestão muito interessante, apresentada por De Mello (1975), foi a de realizar ensaios "mistos". Referindo-se aos ensaios de placa, foi proposto que a prova de carga deveria ser conduzida com carregamentos do tipo lento, para "acentuar os recalques", até o estágio correspondente à tensão admissivel, passando, na segunda metade dos estágios, para carregamentos rápidos, para "minimizar (sic) a tensão de ruptura". Essa proposição foi reavivada por Alonso (1997), com referência a provas de carga mista em estacas.

A norma brasileira de prova de carga, durante todos estes anos, também se modificou com o intuito de reduzir o tempo de execução da prova de carga lenta. É assim que se entende, por exemplo, a modificação implementada na norma brasileira de prova de carga estática em estacas, a NBR 12131, quando de sua revisão em 1991, que consistiu em substituir os tempos dobrados de leitura dos recalques, a partir de $30 \mathrm{~min}$ em cada estágio, por leituras a cada $30 \mathrm{~min}$. Assim, em vez de leituras nos tempos de 1h, 2h, 4h, 8h, etc., passou-se para leituras de $1 \mathrm{~h}, 1 \mathrm{~h} 30,2 \mathrm{~h}, 2 \mathrm{~h} 30,3 \mathrm{~h}$, etc. Dessa forma, manteve-se o critério de estabilização em tempos dobrados, mas ganharam-se alternativas para abreviar a duração do estágio. Por exemplo, ao ultrapassar 2h de estágio, passou a ser possível verificar o critério de estabilização com 3h, comparando-se com a leitura de 1 h30, em vez de necessariamente aguardar a leitura de $4 \mathrm{~h}$.

Nessa mesma revisão da norma, incorporou-se a aceitação da prova de carga rápida (QML, de quick maintained load), a qual não era permitida pela NBR 6121/86 sem um ensaio lento para comparação. Na NBR12131, o ensaio rápido foi preconizado com a duração de todos os estágios pré-fixada em 5 min, independente da estabilização dos recal- 
ques. Ao mesmo tempo, duplicou-se o número previsto de estágios de carregamento, passando de 10 para 20. Assim, conseguiu-se uma redução brutal na duração da prova de carga estática. Em vezes de dias, o ensaio passou a durar algumas poucas horas.

Em todas as adaptações do ensaio lento, até aqui descritas, permaneceu intocável a característica de carga mantida o tempo todo, em cada estágio. Uma única proposição a alterar esse procedimento deve-se a Mohan et al. (1967), pelo qual em cada um dos 10 estágios a carga é mantida apenas no início (5 min nos primeiros estágios e 10 a 15 min nos estágios finais), deixando-se de repor a carga para acelerar a estabilização dos recalques. Trata-se do Método do Equilíbrio que, neste trabalho, recebeu a sigla NML, de NoMaintained Load.

No Brasil, há relatos de três experiências com o método do equilíbrio. Inicialmente, Ferreira (1985) apresentou resultados de provas de carga em duas estacas da ponte sobre o Mar Pequeno, entre Santos e São Vicente (SP). Depois, Benvenutti (2001) realizou provas de carga em tubulões a céu aberto, no Campo Experimental de Fundações da USP / São Carlos. E, por último, Francisco (2004) realizou provas de carga em estacas-modelo, metálicas, com diâmetro de $11,5 \mathrm{~cm}$ e comprimento de $3,5 \mathrm{~m}$, cravadas em argila mole.

O chamado método do equilibro parece ser de grande interesse por reunir as vantagens dos ensaios lento e rápido: os recalques são estabilizados e a duração total do ensaio pode ser de apenas algumas horas. Parece, portanto, justificável um maior número de experiências com esse tipo de ensaio.

Por isso, este trabalho envolve a realização de ensaios pelo método do equilíbrio, com adaptações. São apresentados e discutidos os resultados de provas de carga em modelo, utilizando placa de aço circular rígida de diâmetro de $40 \mathrm{~mm}$. Esses ensaios foram realizados na prensa servo-controlada MTS-815 do Departamento de Geotecnia da USP / São Carlos, utilizando blocos cúbicos (aresta de $0,30 \mathrm{~m}$ ) de solo indeformado, representativos do solo superficial arenoso e colapsível da região de São Carlos - SP. Os ensaios foram conduzidos em duas condições: a) solo inundado; b) não inundado, com monitoração da sucção matricial. Para cada condição, foram empregadas três modalidades de ensaio: a) lento (SML); b) rápido (QML); e c) método do equilíbrio (NML). 
Prova de carga rápida com recalque estabilizado

\section{REVISÃO BIBLIOGRÁFICA}

\subsection{Prova de carga lenta - SML}

O SML (Slow Maintained Load) é descrito na NBR 6489/84 - "Prova de Carga Direta sobre terreno de fundação". As cargas devem ser aplicadas em estágios crescentes de $20 \%$ da provável tensão admissível e em cada estágio a carga é mantida constante até a estabilização do recalque. Essa estabilização pode ser admitida quando a diferença entre duas leituras sucessivas, com intervalos de tempos dobrados 1, 2, 4, 8, 15 e $30 \mathrm{~min}, 2,4,8$ horas, etc., corresponder a um máximo de $5 \%$ do deslocamento havido no estágio. Pode-se substituir os tempos dobrados de leitura dos recalques, a partir de 30 min em cada estágio, por leituras a cada 30 min, de acordo com a modificação implementada na NBR 12131, quando de sua revisão em 1991. O ensaio deve prosseguir até que seja observado um recalque total de $25 \mathrm{~mm}$ ou até que tenha se atingido o dobro da provável tensão admissível. A carga máxima deve ser mantida, pelo menos, durante 12 horas caso não se vá até a ruptura. 0 descarregamento deve ser feito em quatro estágios sucessivos, não superiores a $25 \%$ da carga total e mantendo-se cada estágio até a estabilização dos recalques, analogamente ao carregamento.

Vários trabalhos mencionam o uso desta modalidade em provas de carga em placa. Como um dos trabalhos pioneiros realizados no Brasil sobre esse ensaio, pode-se citar o estudo das fundações dos hangares da antiga Escola Aeronáutica de Pirassununga, hoje conhecida como Academia da Força Aérea, realizado pelo Instituto de Pesquisas Tecnológicas - IPT em 1944. Conforme o relatório do IPT, o solo do local é uniforme até, pelo menos, a profundidade de 8 metros e constituído por areia média pouco argilosa e extremamente porosa. Foram realizadas seis provas de carga em placa de $80 \mathrm{~cm}$ de diâmetro.

A prova de carga 1 foi ensaiada até $300 \mathrm{kPa}$. As provas de carga 2, 3 e 4 foram carregadas até $300 \mathrm{kPa}$, descarregadas e carregadas novamente. Os gráficos tensão x recalque são mostrados na Figura 2.1. É interessante notar que na época o Eng. Milton Vargas, o então engenheiro chefe da seção do IPT, constatou que o comportamento do solo era "ab- 
solutamente anormal", pois o solo aparentemente não apresentava ruptura, porém os recalques observados eram extraordinariamente grandes, da ordem de 80 a $150 \mathrm{~mm}$ para 300 $\mathrm{kPa}$.

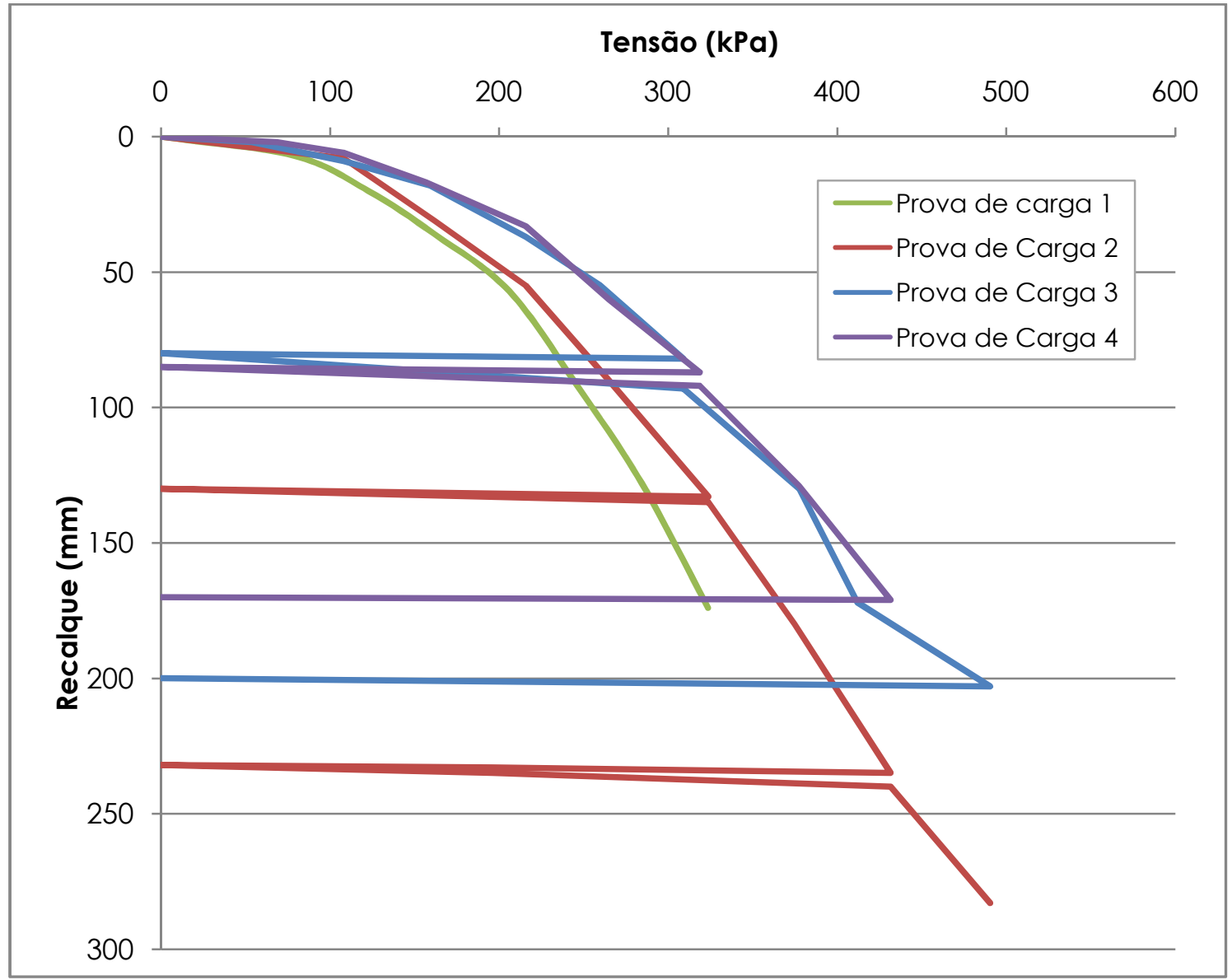

Figura 2. 1- Gráficos tensão x recalque das provas de carga de 1 a 4 (Adaptado de IPT, 1944)

As provas de carga 5 e 6 foram efetuadas no mesmo local das provas 3 e 4, porém com a compactação prévia do solo abaixo da placa, sendo os resultados desses quatro ensaios agrupados na Figura 2.2. Pode-se observar que, para a tensão de 300 kPa, a redução dos recalques foi de aproximadamente $90 \%$. A compactação do solo foi utilizada como solução para a redução da compressibilidade de solos porosos. Com isso, foi possível viabilizar o emprego de fundações por sapata. 
Prova de carga rápida com recalque estabilizado

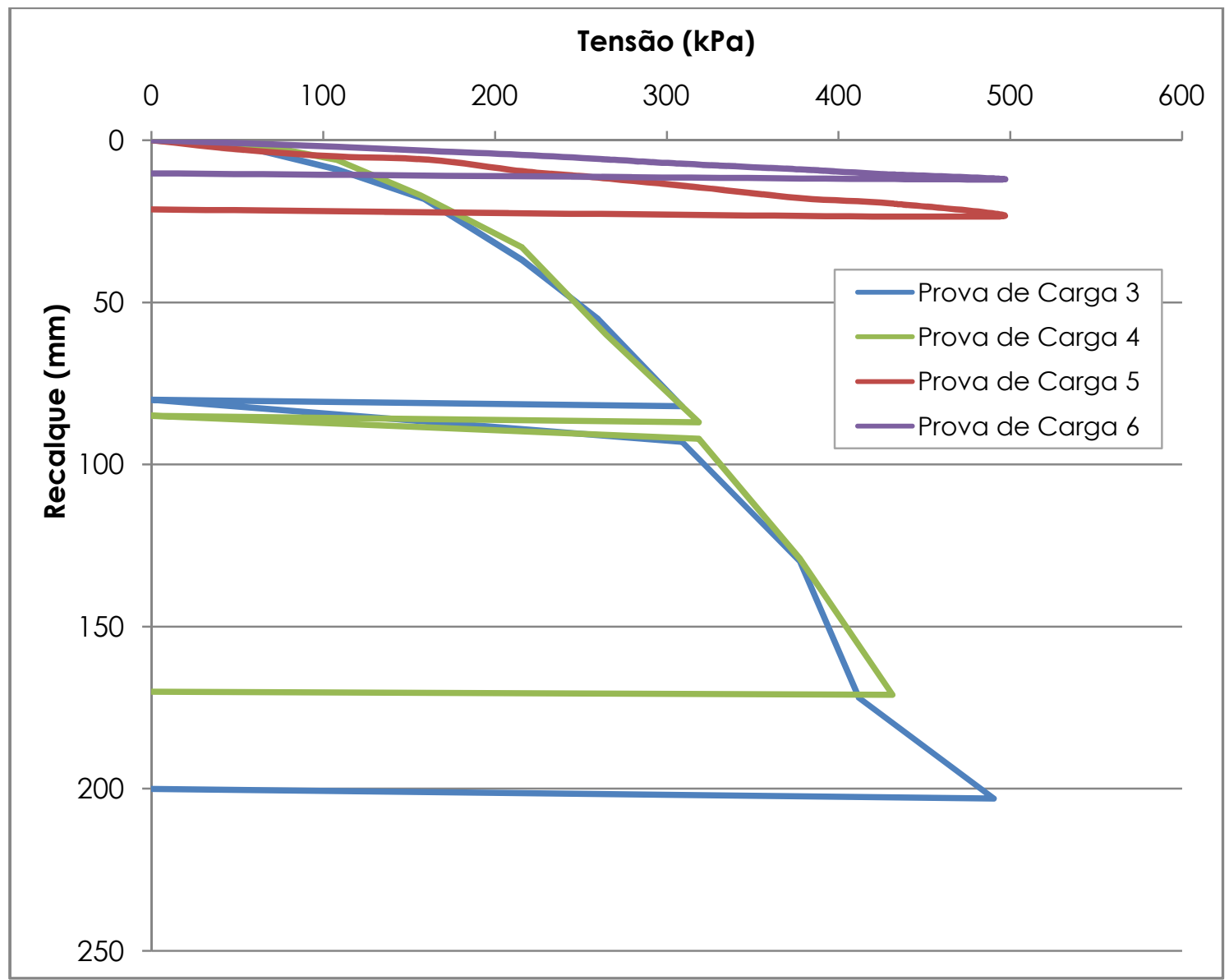

Figura 2.2- Gráficos tensão x recalque das provas de carga de 3 a 6 (Adaptado de IPT, 1944)

Outro trabalho importante, também realizado pelo IPT, ocorreu em 1954. Para examinar a viabilidade do emprego de fundação por sapatas nas futuras instalações da Escola de Engenharia de São Carlos, foram executadas três provas de carga em placa em profundidades diferentes (1, 5 e 7 m). Na Figura 2.3 são apresentados os gráficos tensão x recalque, onde é possível verificar que a capacidade de carga aumenta com a profundidade. 


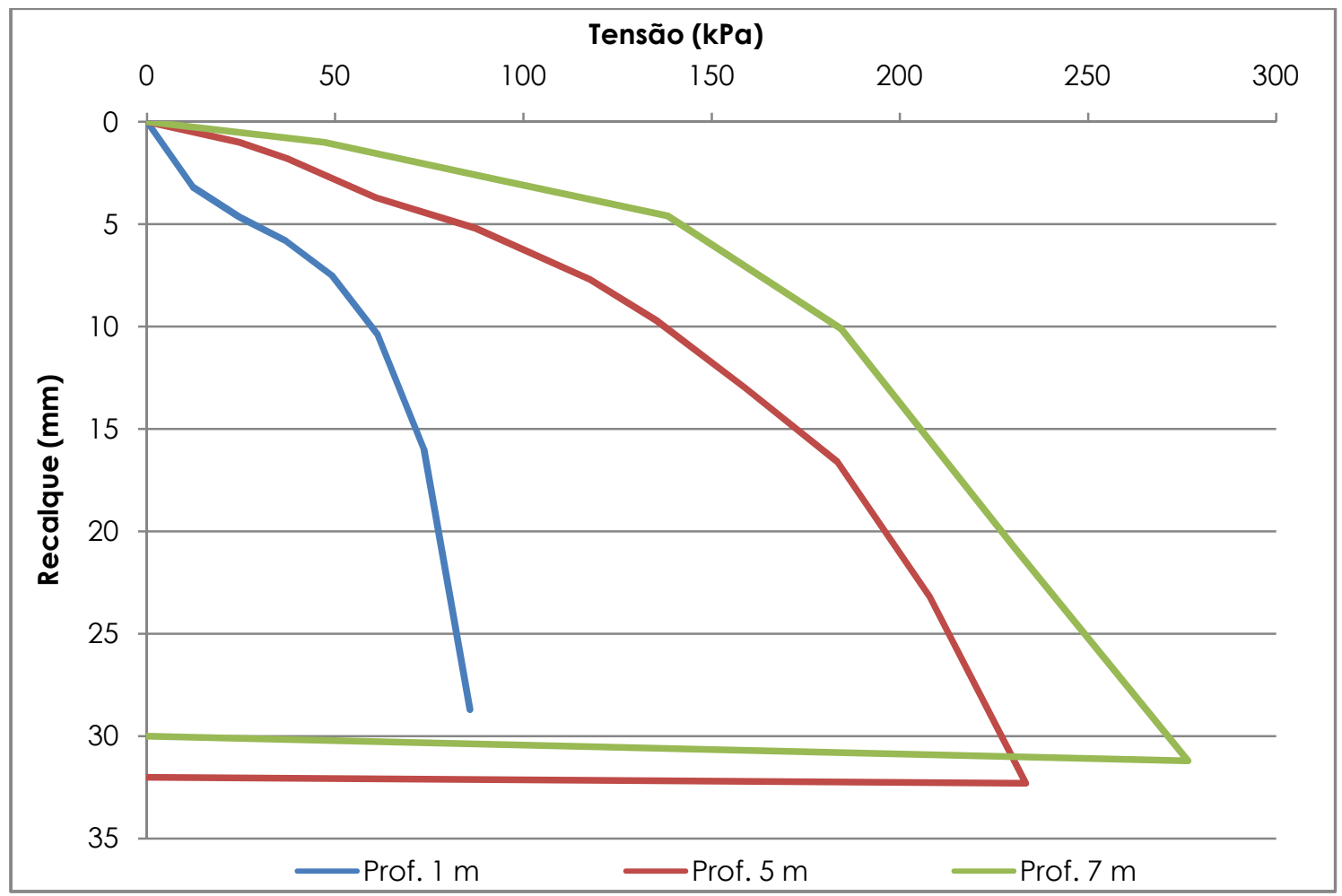

Figura 2.3- Gráficos tensão x recalque em profundidades diferente (Adaptado de IPT, 1954)

\subsection{Prova de carga rápida - QML}

No Brasil, não há norma específica para a realização do ensaio rápido em elemento de fundação superficial. Contudo, costuma-se adotar as recomendações da NBR 12131/91 - "Estacas - Prova de Carga Estática", para o ensaio QML (Quick Maintained Load). A referida norma especifica que a carga aplicada em cada estágio não deve ser superior a 10\% da carga admissível prevista e ser aplicada por um período de 5 minutos, independente da estabilização dos recalques. Os recalques devem ser lidos ao menos no início e no término de cada estágio de carga.

O descarregamento é feito em quatro estágios, com a leitura similar ao do carregamento. Uma última leitura é feita após o descarregamento total.

Fellenius (1975) recomenda que cada estágio de carga no ensaio rápido seja mantido por quinze minutos com leituras de deslocamentos a cada três minutos. Considerando um ensaio com 20 estágios de carregamentos e quatro de descarregamento, o tempo total na proposição de Fellenius é de seis horas, o que viabiliza a realização do ensaio dentro do 
Prova de carga rápida com recalque estabilizado

período diurno. Em consequência, os custos envolvidos e o tempo do ensaio são diminuídos, caracterizando uma boa vantagem deste ensaio.

O Departamento de Geotecnia da EESC-USP tem uma ampla experiência nessa metodologia de ensaios, com a realização de várias pesquisas no seu Campo Experimental de Fundações.

Dentre elas, Costa (1999), que realizou ensaios SML e QML em placa a 1,5 m de profundidade, com inundação, e as Figuras 2.4 e 2.5 apresentam as respectivas curvas tensão $x$ recalque. Também realizou ensaios sem inundação, porém não há resultados na mesma sucção.

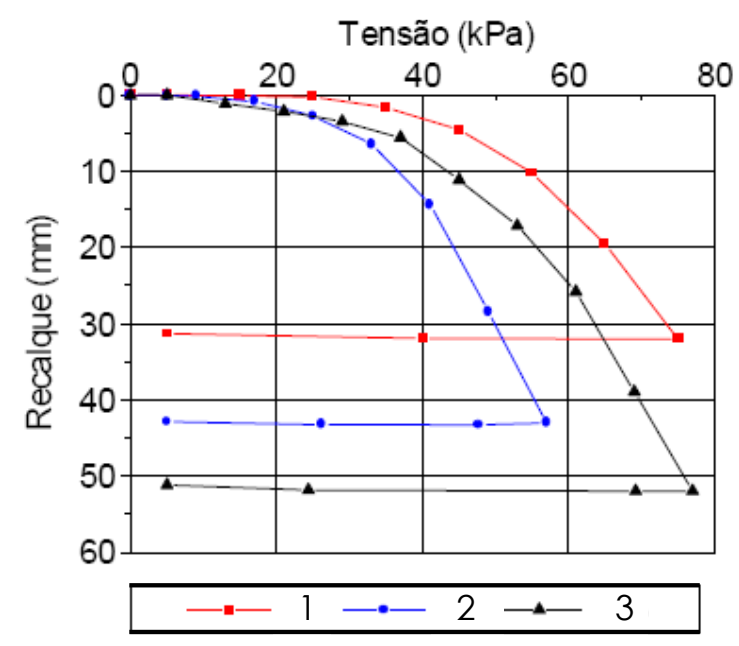

Figura 2.4- Curvas tensão x recalque dos ensaios SML inundados (COSTA, 1999)

Tensão $(\mathrm{kPa})$

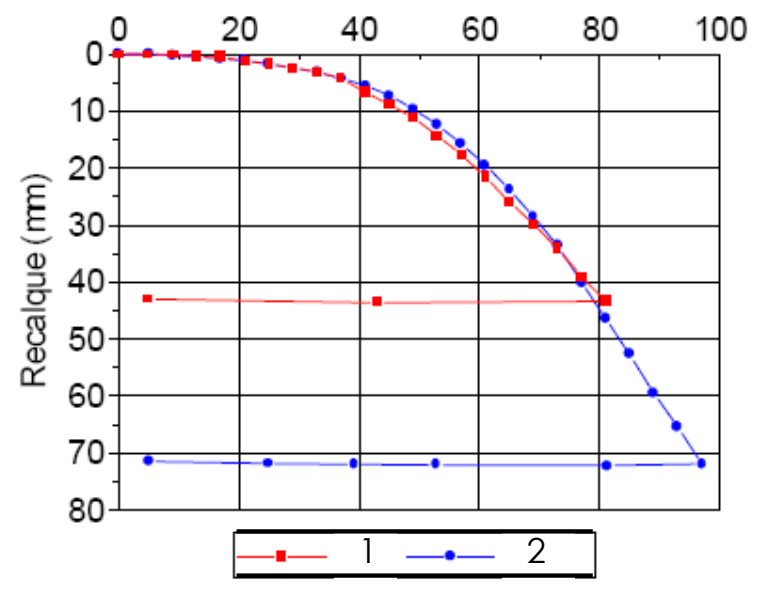

Figura 2.5- Curvas tensão x recalque dos ensaios QML inundados (COSTA, 1999) 
Os ensaios SML e QML são comparados na Figura 2.6. COSTA (1999) conclui que a capacidade de carga obtida para os ensaios rápidos é aproximadamente $10 \%$ maior que a obtida nos ensaios lentos.

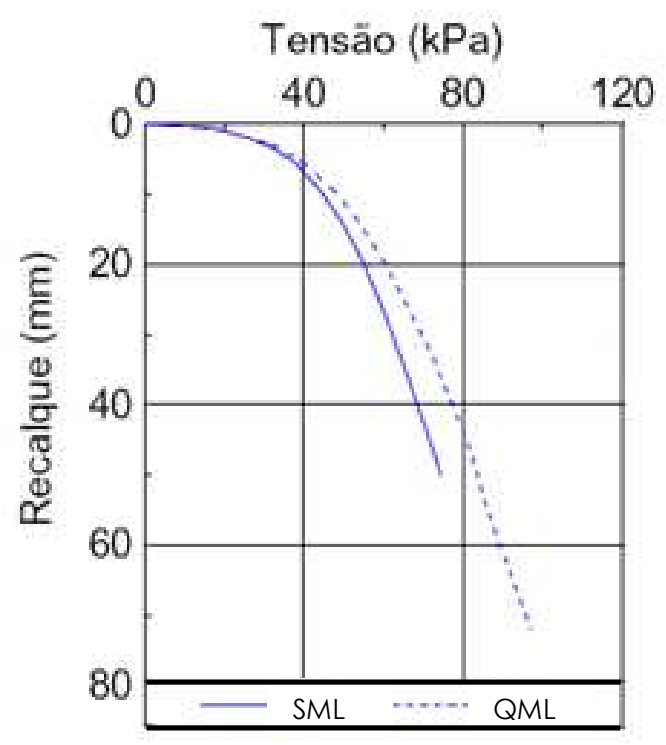

Figura 2.6- Curvas tensão x recalque para os ensaios inundados (COSTA, 1999)

Macacari (2001) apresenta resultados de provas de carga QML, também realizadas no mesmo Campo Experimental de Fundações, mas em diferentes profundidades $(1,5,4,0$, 6,0 e 8,0 m) com monitoramento da sucção matricial, com o intuito de verificar a variação da capacidade de carga com a sucção e a profundidade. Os resultados podem ser observados nas Figuras 2.7 a 2.10. O valor entre parênteses expressa o valor médio da sucção matricial durante a realização do ensaio.

O autor conclui que a sucção possui grande influência na capacidade de carga, para a mesma profundidade. Já com o aumento de profundidade ocorre um acréscimo da capacidade de carga, para um mesmo nível de sucção. 
Prova de carga rápida com recalque estabilizado

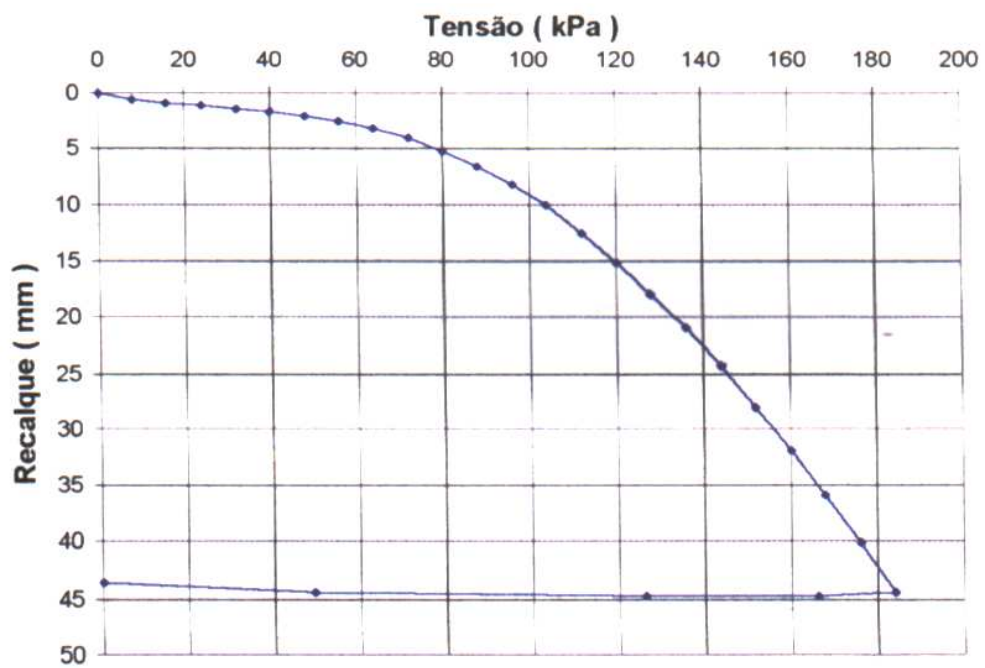

Figura 2.7- Curva tensão x recalque para a profundidade de 1,5 m (33 kPa) (MACACARI, 2001)

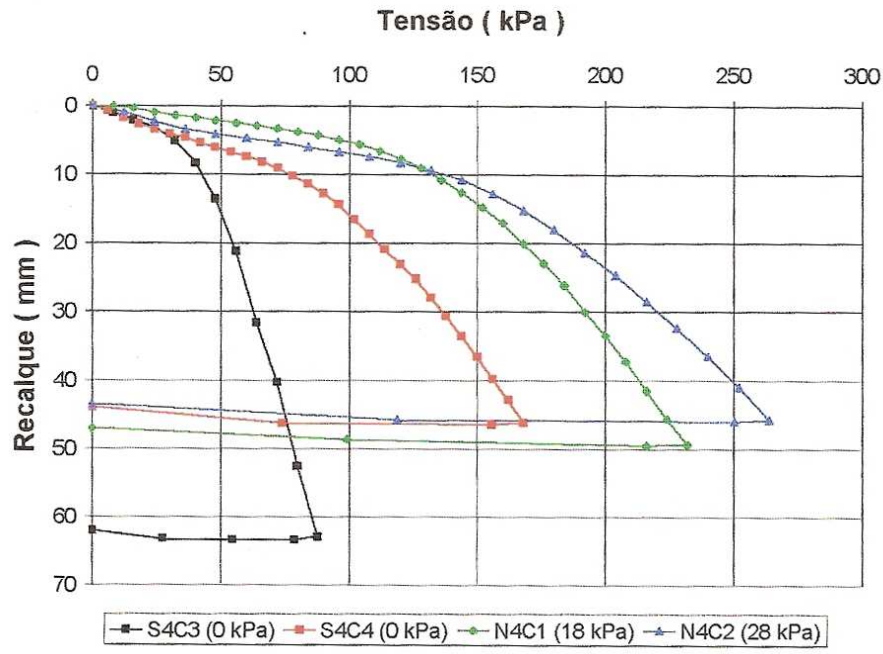

Figura 2.8- Curvas tensão x recalque para a profundidade de 4,0 m (MACACARI, 2001)

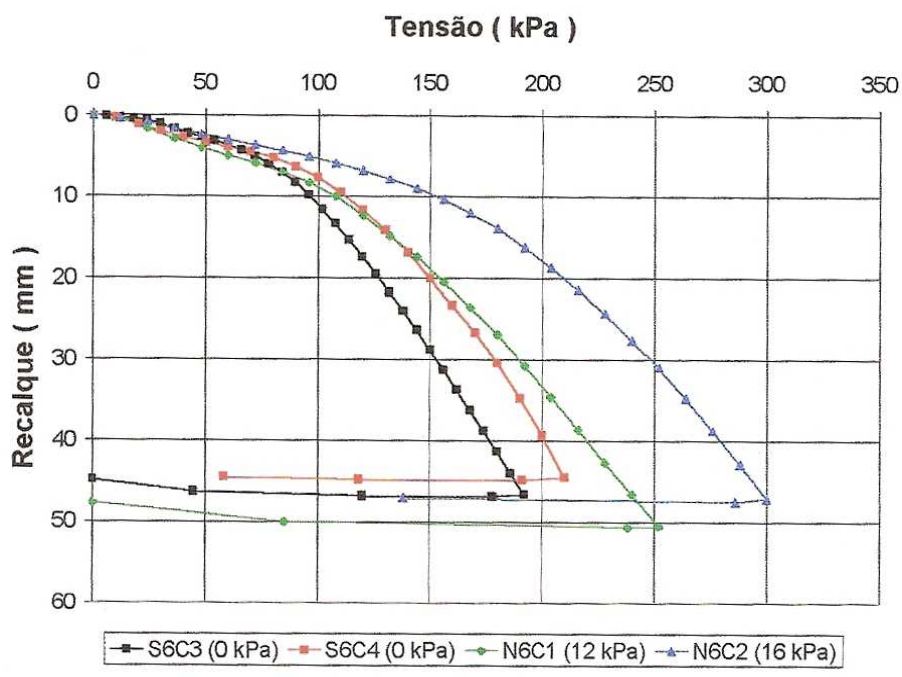

Figura 2.9- Curvas tensão x recalque para a profundidade de 6,0 m (MACACARI, 2001) 


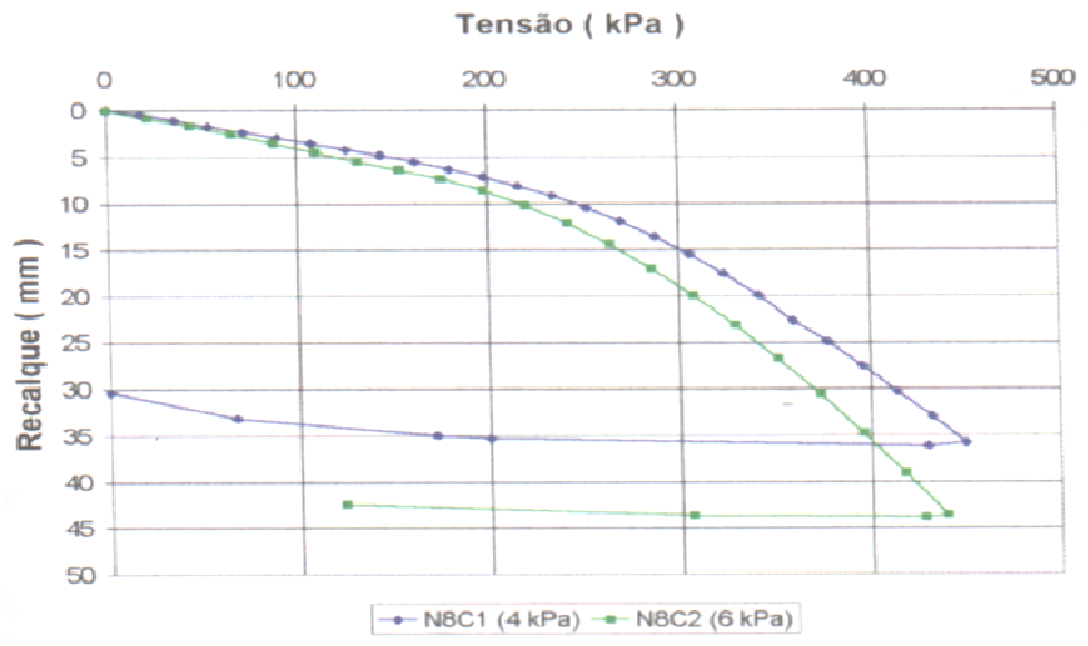

Figura 2.10- Curvas tensão $x$ recalque para a profundidade de 8,0 m (MACACARI, 2001)

Vianna (2005) realizou provas de carga QML, no mesmo Campo Experimental de Fundações, em placas de diferentes diâmetros $(0,2,0,4$, e 1,5m), com medida de sucção matricial. As curvas carga $x$ recalque são apresentadas nas Figuras 2.11 a 2.13. Os valores apresentados entre parênteses referem-se à sucção média, em kPa. A autora complementa seus dados com os resultados obtidos por COSTA(2000) e MACACARI (2001), para a placa de $0,8 \mathrm{~m}$.

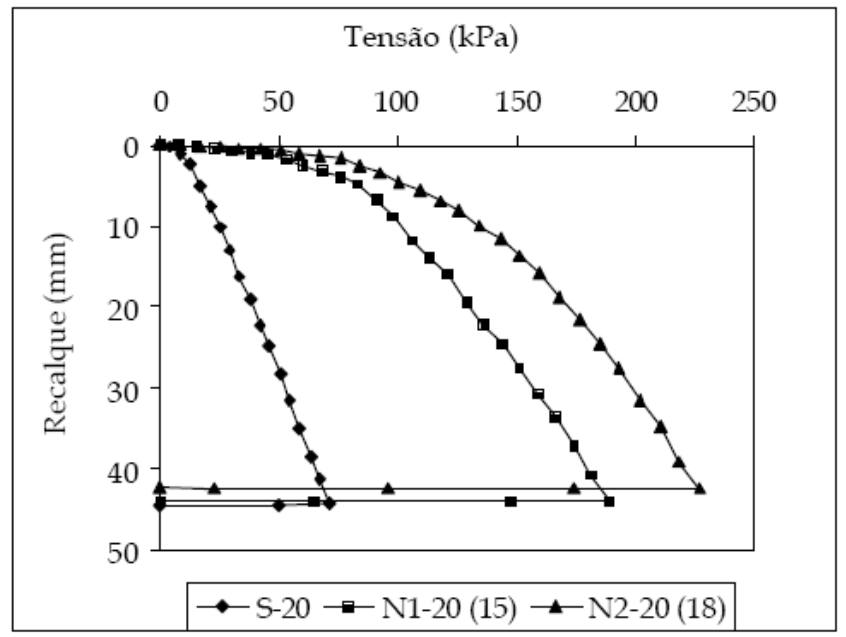

Figura 2.1 1- Curvas tensão x recalque dos ensaios para a placa de 0,20 m (VIANNA, 2005) 
Prova de carga rápida com recalque estabilizado

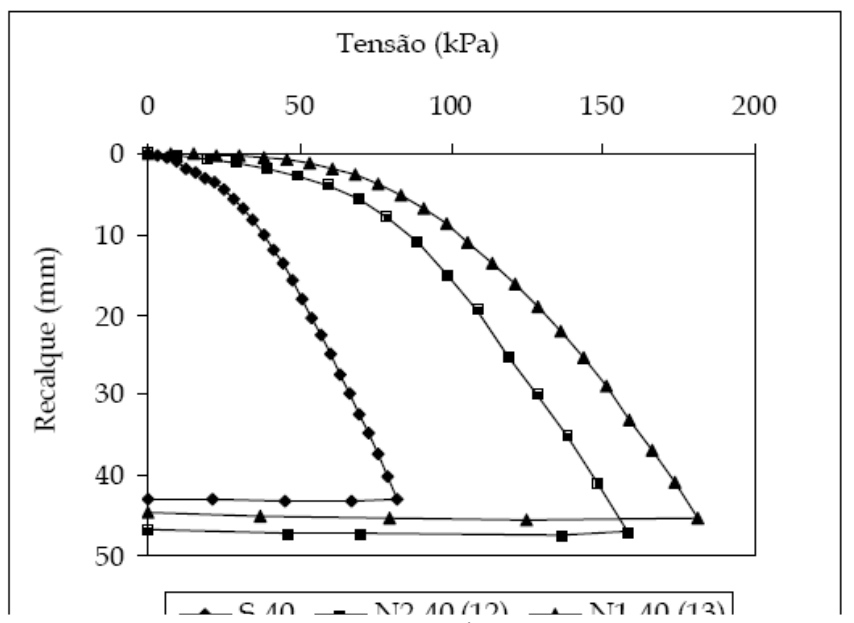

Figura 2. 12 - Curvas tensão $x$ recalque dos ensaios para a placa de $0,40 \mathrm{~m}$ (VIANNA, 2005)

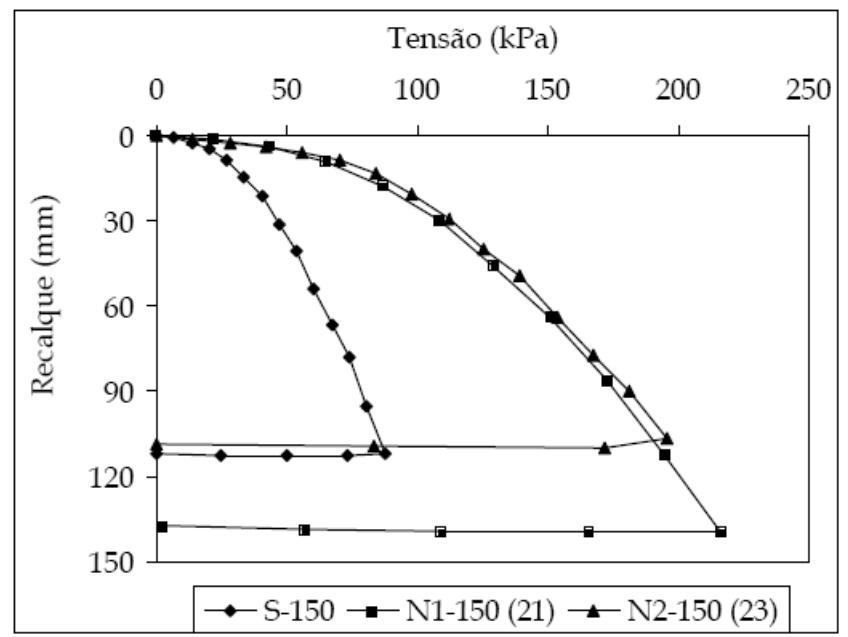

Figura 2.13 - Curvas tensão x recalque dos ensaios para a placa de 1,50 m (VIANNA, 2005)

Para o solo inundado, pode-se fazer uma análise direta da influência exclusiva da dimensão da sapata ou placa na capacidade de carga. A Figura 2.14 apresenta o gráfico diâmetro x capacidade de carga, na condição inundada, e pode-se perceber que a variação da capacidade de carga com o diâmetro não ocorre segundo uma função linear da dimensão da sapata ou placa, como admitem os método teóricos, e que a capacidade de carga não aumenta ao passar do diâmetro de 0,80 m para 1,5 m. 


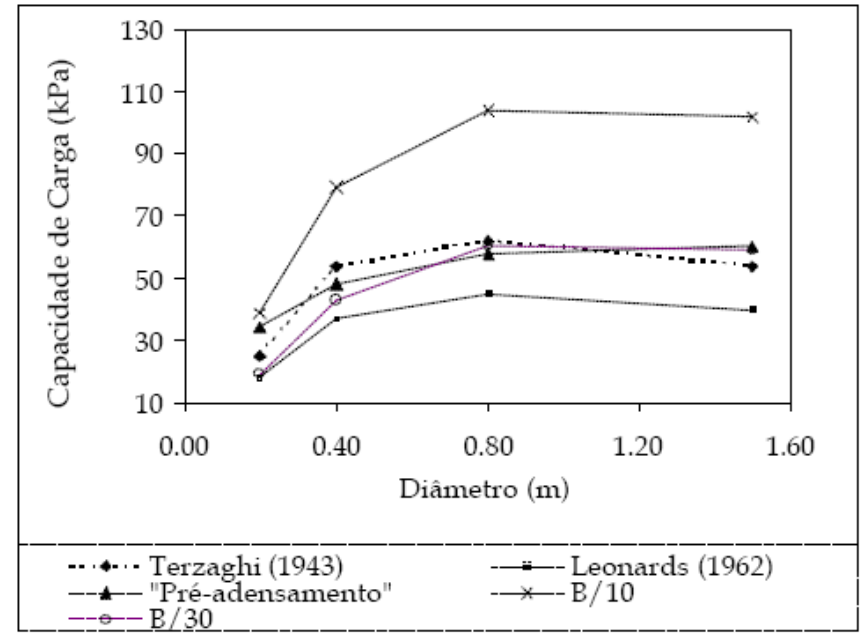

Figura 2.14 - Capacidade de carga x diâmetro da placa ou sapata, ensaios inundados (VIANNA, 2005)

\subsection{Prova de carga mista - MML}

Para De Mello (1975), na prática, a maioria dos problemas de fundações são relativos a recalques, porém a análise quanto à ruptura é indispensável. O autor propõe então, que a primeira parte do ensaio de placa seja conduzida como SML, para "acentuar recalques" e passando na segunda metade do ensaio para o QML, porque este seria mais "crítico (sic) para ruptura". Esta modalidade de ensaio ficou conhecida como prova de carga mista, com a sigla MML (Mixed Maintained Load) adotada por Costa (1999), que realizou três provas de carga MML em placa de $80 \mathrm{~cm}$ de diâmetro, na condição inundada, no Campo Experimental de Fundações do Departamento de Geotecnia da EESC-USP. Os gráficos tensão x recalque podem ser observados na Figura 2.15. 
Prova de carga rápida com recalque estabilizado

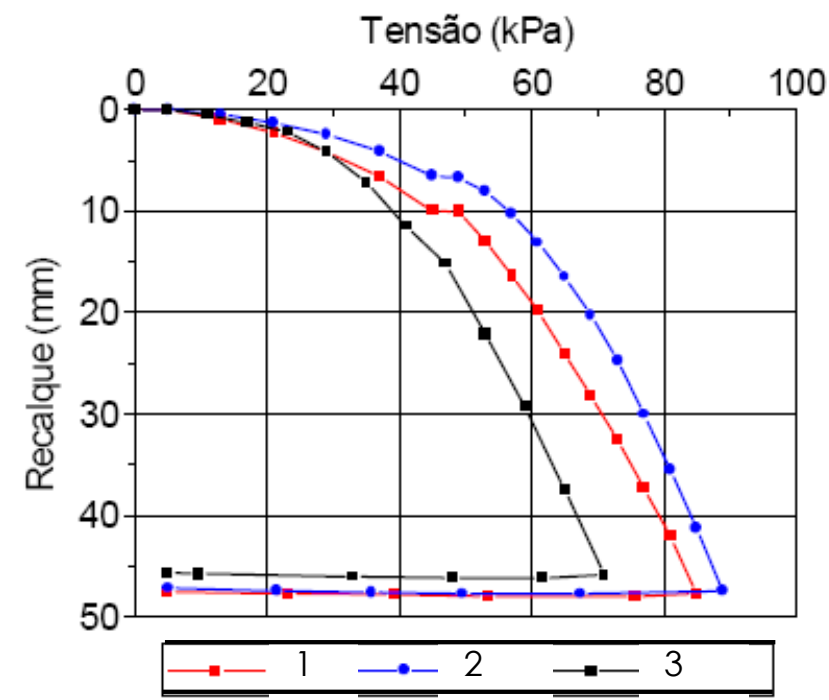

Figura 2.15 - Curvas tensão x recalque dos ensaios MML, inundados (COSTA, 1999)

O autor conclui que as curvas das provas de carga mista apresentam um comportamento semelhante ao das curvas do SML e QML, conforme Figura 2.16, denotando ser viável sua aplicação ao solo estudado.

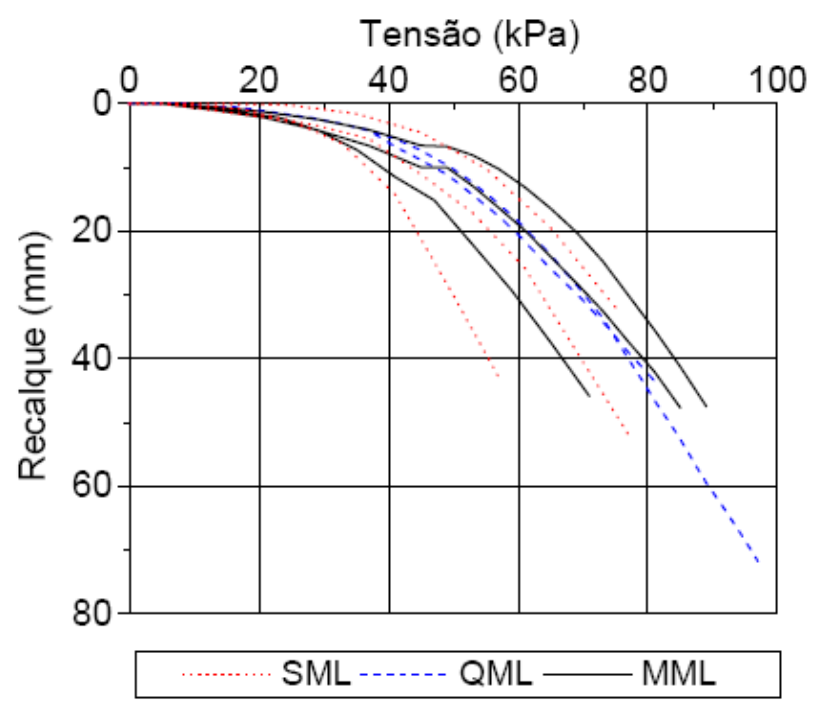

Figura 2.16 - Curvas tensão x recalque dos ensaios inundados das diversas modalidades (COSTA, 1999)

Porém, além de introduzir uma espécie de patamar no estágio de mudança de modalidade de ensaio, o que dificulta o tratamento como curva única, a prova de carga QML não minimiza a capacidade de carga como preconizado por De Mello (1975). 


\subsection{Método do Equilíbrio - NML}

O Método do Equilíbrio, proposto por Mohan et al. (1967) para estacas apresenta a inovação de não impor a carga mantida durante o estágio todo. Neste trabalho adota-se a sigla NML, de No-Mainteined Load. O procedimento sugerido pelos autores é que em cada estágio, de cerca de $10 \%$ da carga última estimada, a carga seja mantida durante 3 a 5 min. Após este período não se repõe mais a carga para acelerar a estabilização dos recalques. Ao final do estágio a carga também ocorreria a estabilização da carga. No estágio seguinte é aplicado um incremento maior que $10 \%$ da carga última para retornar ao valor programado inicialmente. Para cargas mais elevadas, seria conveniente manter a carga inicial por um período de 10 a 15 min.

Segundo Mohan et al. (1967), em solos arenosos a estabilização da carga e do recalque é atingida rapidamente e em solos argilosos demora um pouco mais. O tempo total exigido por este método é geralmente reduzido para cerca de um terço em uma prova de carga lenta.

Mohan et al. (1967), acreditam que seu método produza resultados muito semelhantes à prova de carga mantida lenta, e com finalidade de comparação, realizaram uma série de provas de carga, em sete obras, entre elas de estacas cravadas e estacas moldadas "in loco". Em duas obras uma comparação com o método de deformação controlada (CRP) também foi feita. A mesma estaca foi utilizada para ambos os ensaios a fim de evitar incertezas decorrentes da utilização de diferentes estacas. O método do equilíbrio foi utilizado alternativamente com a prova de carga lenta na mudança de cada estágio.

As curvas carga $x$ recalque obtidas nas provas de carga realizadas em Nizam Palace, na cidade de Calcutta, onde foram ensaiadas duas estacas escavadas com 45,8 cm de diâmetro e aproximadamente 22 metros de profundidade são apresentadas nas Figuras 2.17 e 2.18.

Em ambas as Figuras pode-se observar um bom ajuste da curva carga $\mathrm{x}$ recalque passando pelos pontos obtidos nos ensaios SML e NML. 
Prova de carga rápida com recalque estabilizado

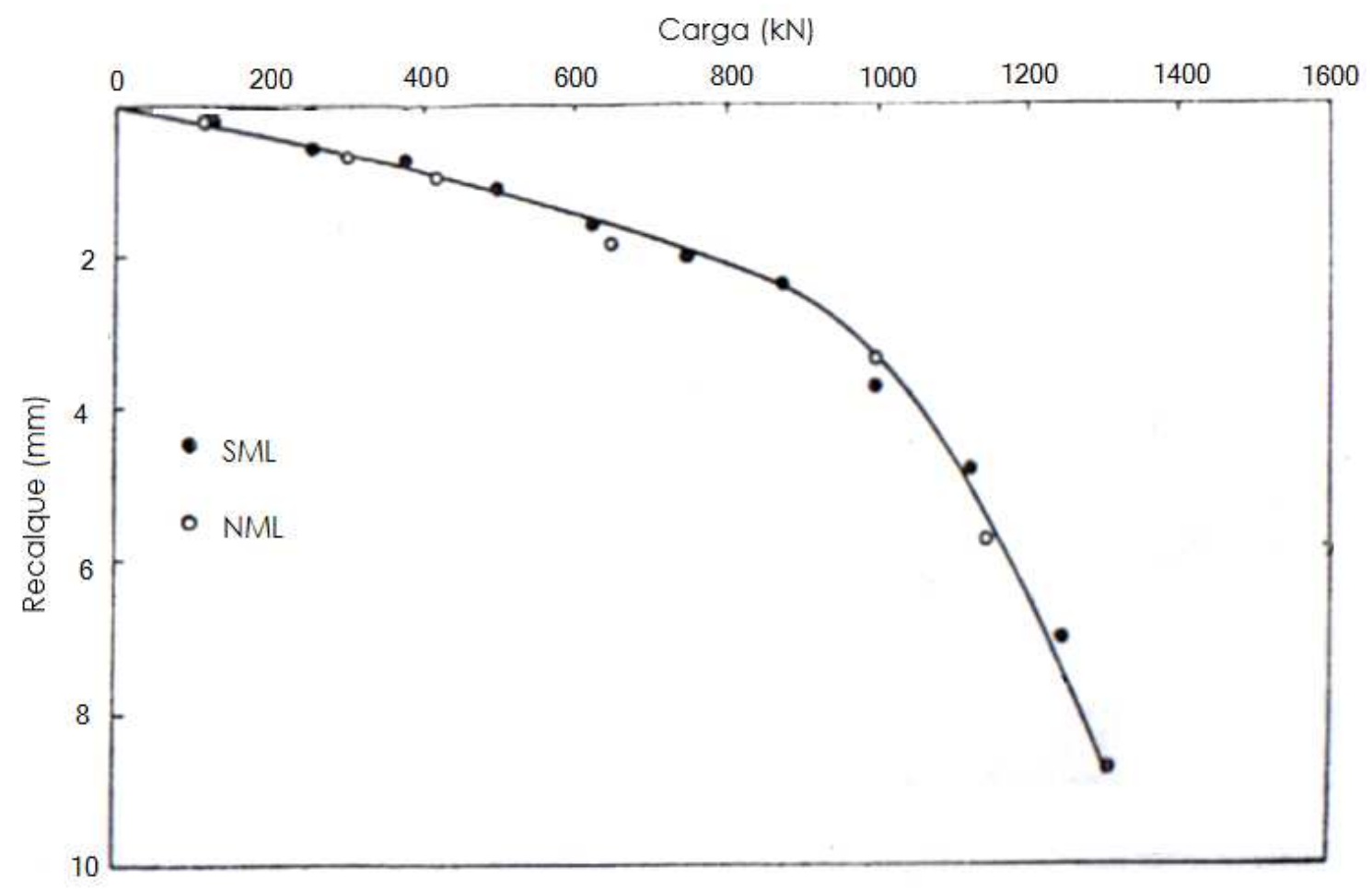

Figura 2.17 - Curva carga x recalque da estaca 1 (MOHAN et al., 1967)

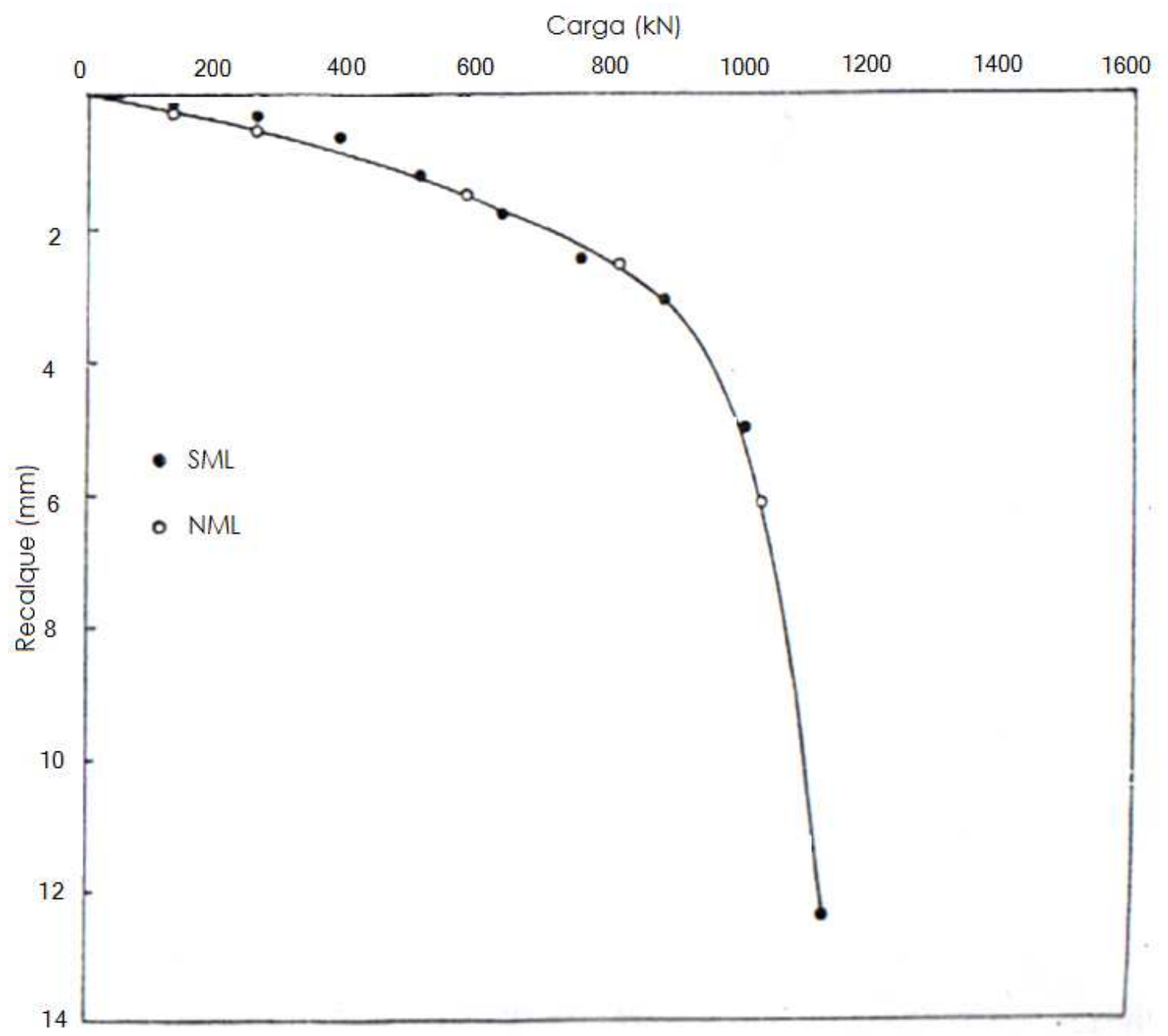

Figura 2.18 - Curva carga x recalque da estaca 2 (MOHAN et al., 1967) 
Mohan et al. (1967) também ensairam uma estaca escavada de aproximadamente $43 \mathrm{~cm}$ de diâmetro e 10,7 metros de profundidade num terreno de areia fina e estrato de siltes e apoiada em argila siltosa. A estaca foi primeiramente ensaiada pelos métodos NML e SML, alternados, e por fim pelo método de penetração a taxa constante (CRP). A curva carga $x$ recalque é mostrada na Figura 2.19. Os pontos obtidos pelo SML e NML constituem praticamente uma mesma curva. Já os pontos obtidos pelo CRP indicam valores de carga cerca de $10 \%$ superiores as cargas correspondentes a curva extendida (linha pontilhada) das outras duas modalidades. Segundo Mohan, isto está de acordo com conclusões anteriores (WHITAKER AND COOKE, 1961), em que o método de penetração a carga constante fornecia valores de carga mais elevados do que o SML.

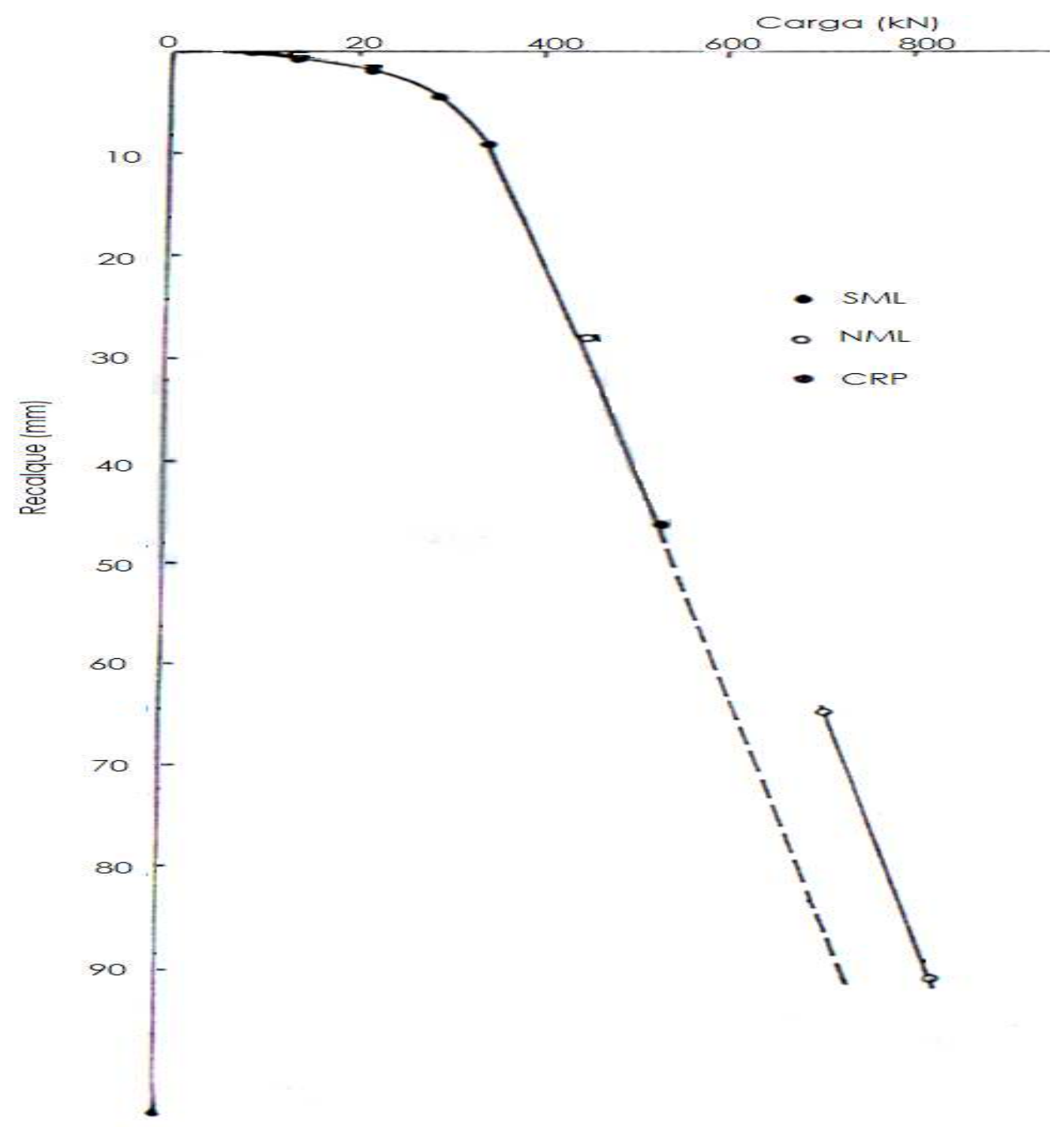

Figura 2.19 - Curva carga x recalque da estaca 3 (MOHAN et al., 1967) 
Prova de carga rápida com recalque estabilizado

Mohan et al. (1967) ainda apresentam resultados de uma prova de carga para uma estaca pré-moldada de concreto, de seção quadrada de $30,5 \mathrm{~cm}$. A estaca foi cravada até 10,7 m, atravessando uma camada de areia média e apoiada numa camada de areia fina siltosa. A Figura 2.20 apresenta o resultado desta prova de carga e os pontos obtidos pelas duas metodologias. Novamente se observa que uma curva única se ajusta bem a todos os pontos.

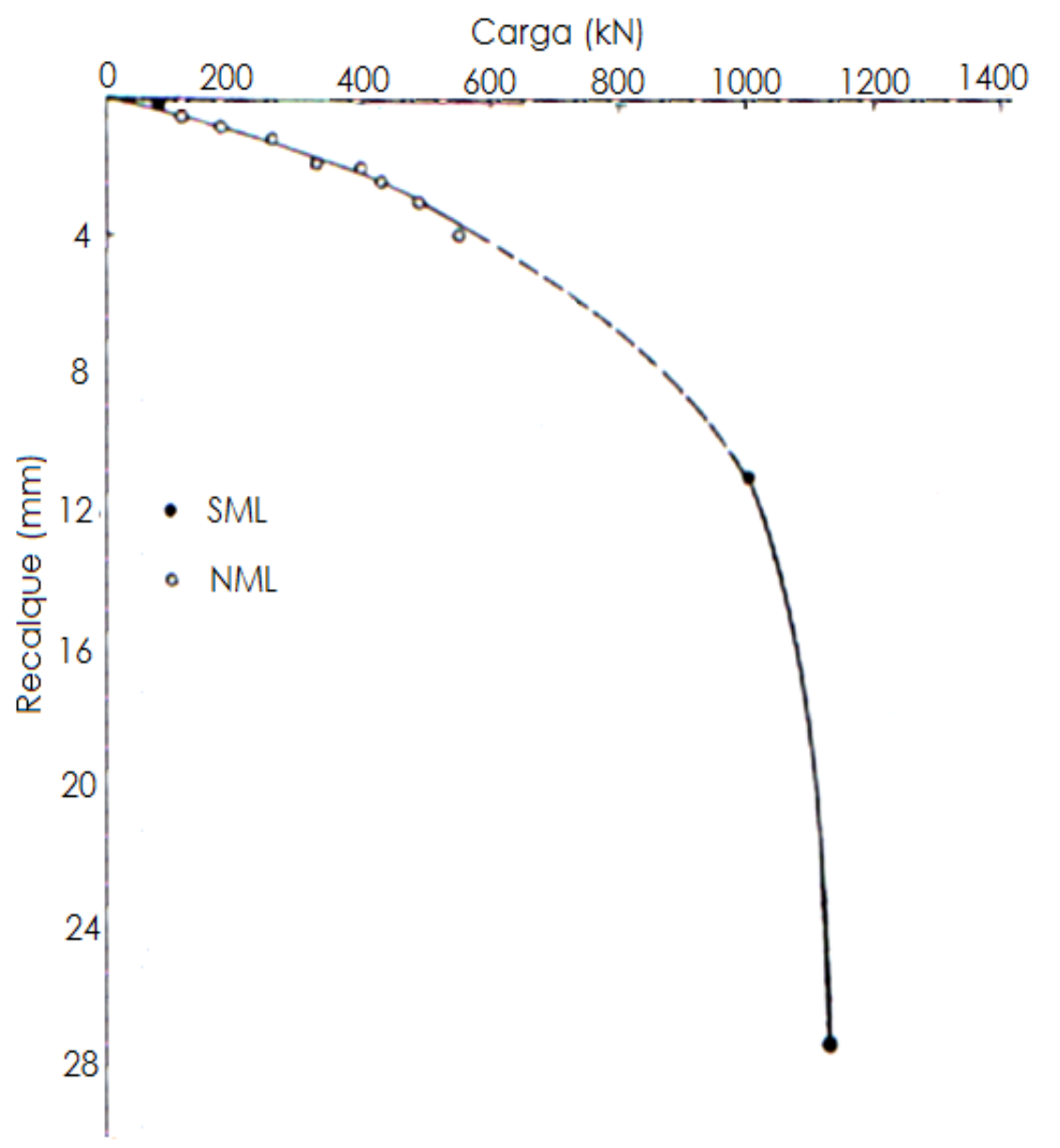

Figura 2.20 - Curva carga x recalque da estaca 4 (MOHAN et al., 1967) 
Com o objetivo de verificar o efeito da modalidade de carregamento na capacidade de carga de estacas, Ferreira (1985) examinou provas de cargas realizadas pelo DERSA (Desenvolvimento Rodoviário de São Paulo S. A.) em duas estacas (PV-2 e PV-3) da ponte sobre o "Mar Pequeno", entre Santos e São Vicente (SP). As estacas ensaiadas eram de tubos de aço de $65 \mathrm{~cm}$ de diâmetro e chapa com 3/4" de espessura. O comprimento médio atingido foi de $44 \mathrm{~m}$.

Foram efetuadas três provas de carga em cada estaca, sendo a primeira SML, a segunda com critério de estabilização mais rigoroso que o da SML (que cada estágio durasse pelo menos 16 horas) e a última pelo MML.

As provas de carga foram repetidas na mesma estaca, para que, segundo o autor, pudesse presumir que a estaca e solo fossem perfeitamente iguais e que as alterações ocorridas se referissem apenas à modalidade do carregamento. Para uma carga admissível estimada em $2500 \mathrm{kN}$, os valores de recalque ( $\rho$ ) são apresentados na tabela 2.1.

Tabela 2. 1- Recalque para carga admissível de 2500 kN (FERREIRA, 1985)

\begin{tabular}{cccccc}
\hline \multirow{2}{*}{ Modalidade } & \multicolumn{3}{c}{$P V-2$} & & \multicolumn{3}{c}{$P V-3$} \\
\cline { 2 - 3 } \cline { 5 - 6 } \cline { 5 - 6 } SML & $\dagger(\mathrm{h})$ & $\rho(\mathrm{mm})$ & & $\dagger(\mathrm{h})$ & $\rho(\mathrm{mm})$ \\
\hline Estabilização Rigorosa & 88 & 6,6 & & 130 & 5,6 \\
NML & 24 & 6,5 & & 30 & 4,2 \\
\hline
\end{tabular}

Na carga admissível, o NML apresentou valores de recalque aproximadamente $10 \%$ menores que os apresentados pelo SML. As curvas carga $x$ recalque obtidas pelo SML e NML, nas duas estacas (PV-2 e PV-3), conforme as Figuras 2.21 e 2.22, são similares. Os resultados, entretanto podem ter influência do efeito do reensaio. 
Prova de carga rápida com recalque estabilizado

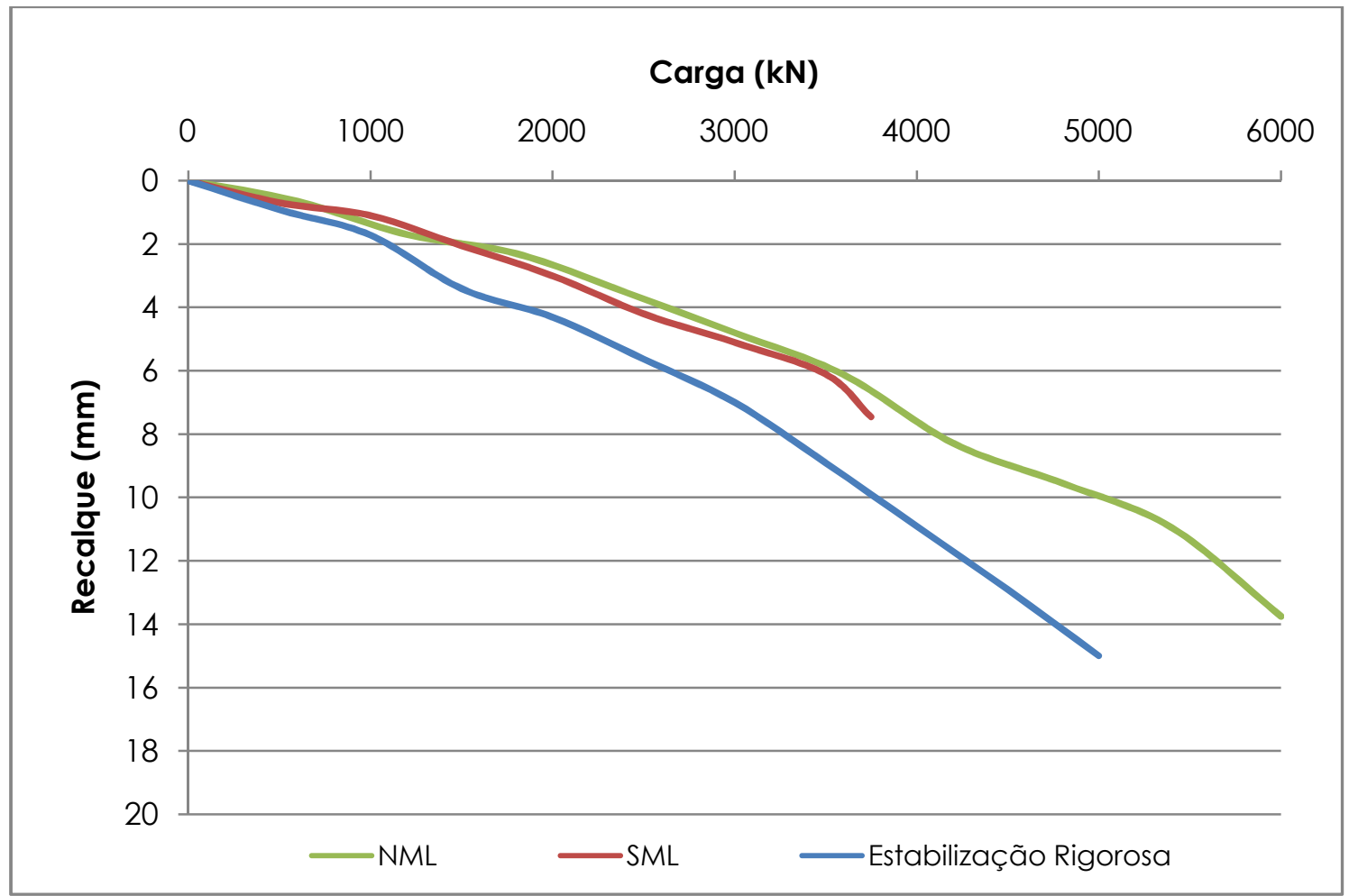

Figura 2. 21 - Gráfico carga x recalque para a estaca PV-2 (modificado de FERREIRA, 1985)

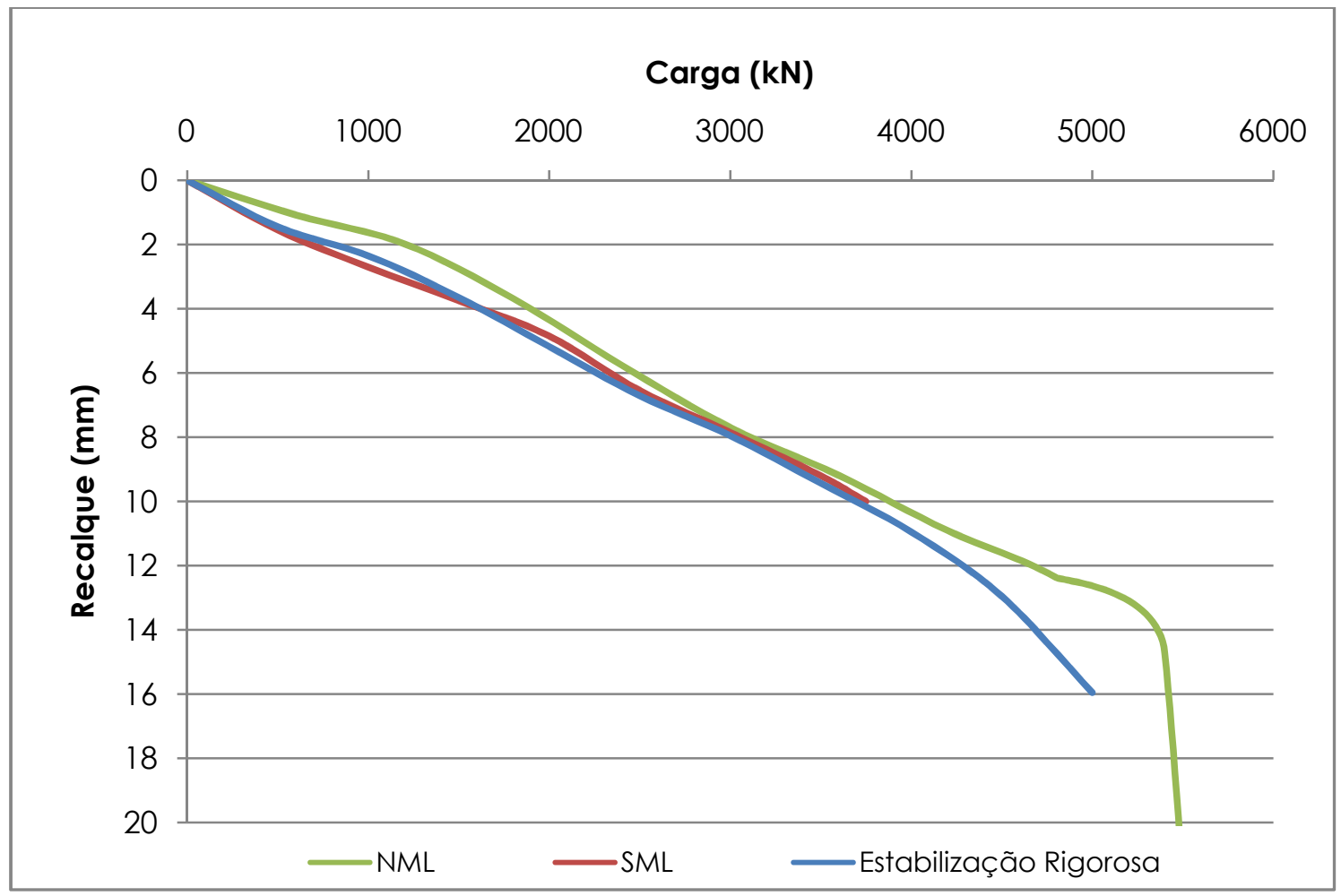

Figura 2.22 - Curva carga x recalque para a estaca PV-3 (modificado de FERREIRA, 1985) 
Francisco (2004) realizou provas de carga pelo QML e MNL em estacas-modelo, metálicas, com diâmetro de $11,5 \mathrm{~cm}$ e comprimento de $3,5 \mathrm{~m}$, cravadas em argila mole, cujas curvas carga $x$ recalque são apresentadas nas Figuras 2.23 e 2.24.

Constata-se que a proximidade dos valores de capacidade de carga obtidos nos dois ensaios, com ligeira superioridade de 10\% para o QML.

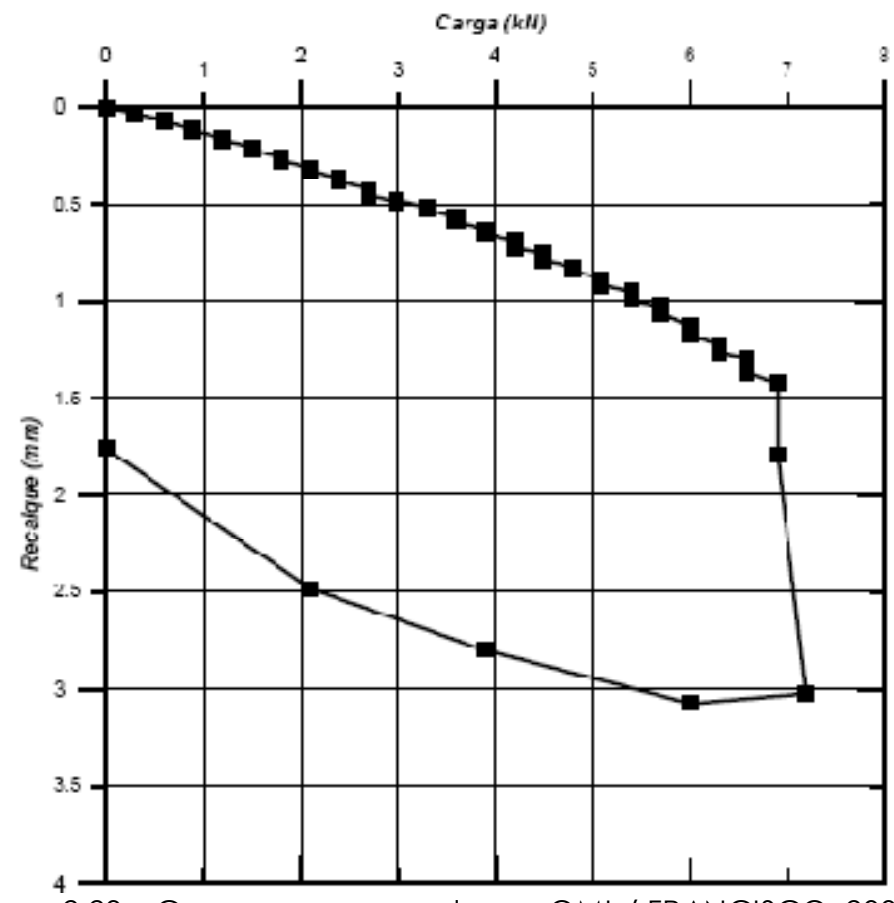

Figura 2.23 - Curva carga $\times$ recalque - QML ( FRANCISCO, 2004)

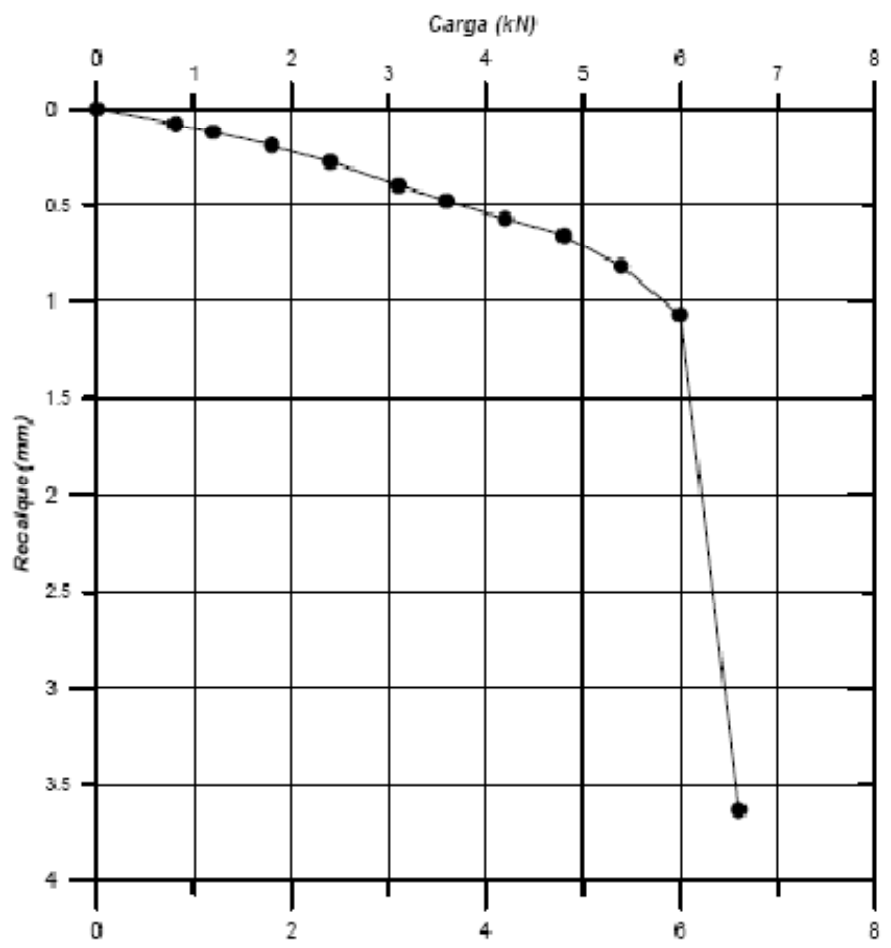

Figura 2.24 - Curva carga $\times$ recalque - NML ( FRANCISCO, 2004) 
Prova de carga rápida com recalque estabilizado

Durante a execução da prova de carga pelo NML, Francisco (2004) realizou leituras do recalque e da carga, não mantida, com o intuito de se estabelecer o momento mais oportuno para se interromper um determinado estágio de carregamento, conforme as Figuras 2.25 e 2.26. Nota-se que, o recalque estabilizava a partir de um certo tempo, enquanto que a carga continuava a diminuir o seu valor.

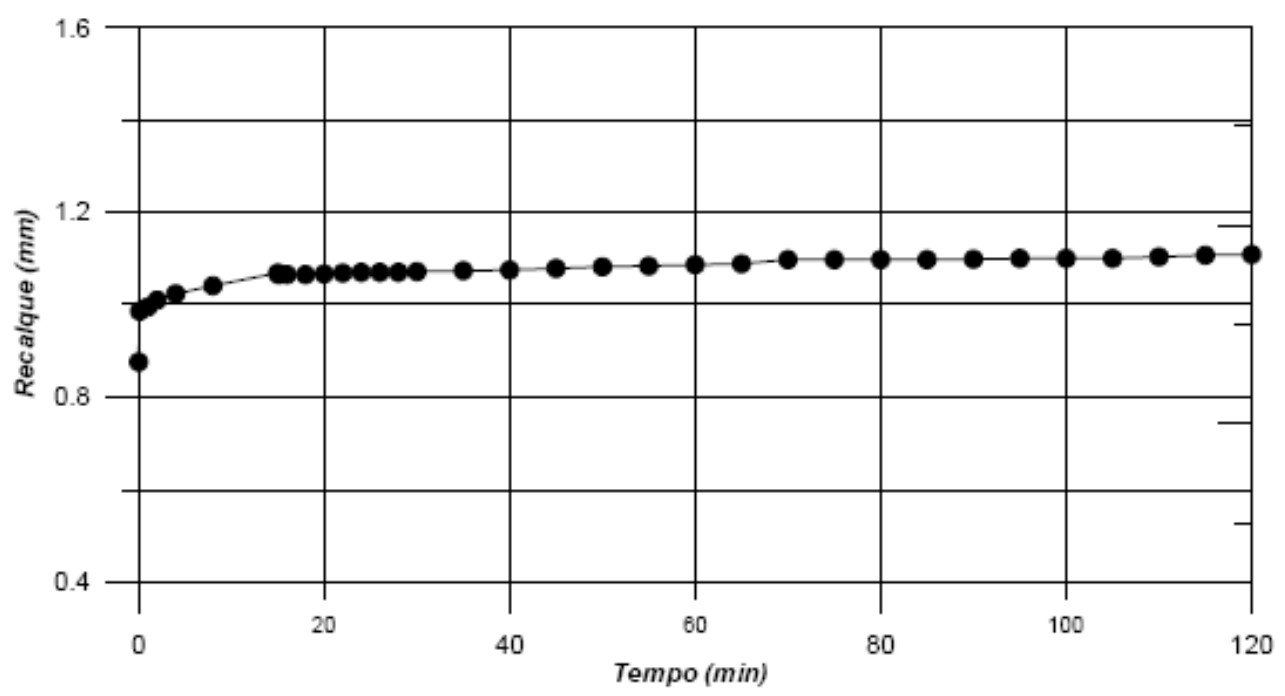

Figura 2.25 - Variação do recalque com o tempo em um estágio (FRANCISCO, 2004)

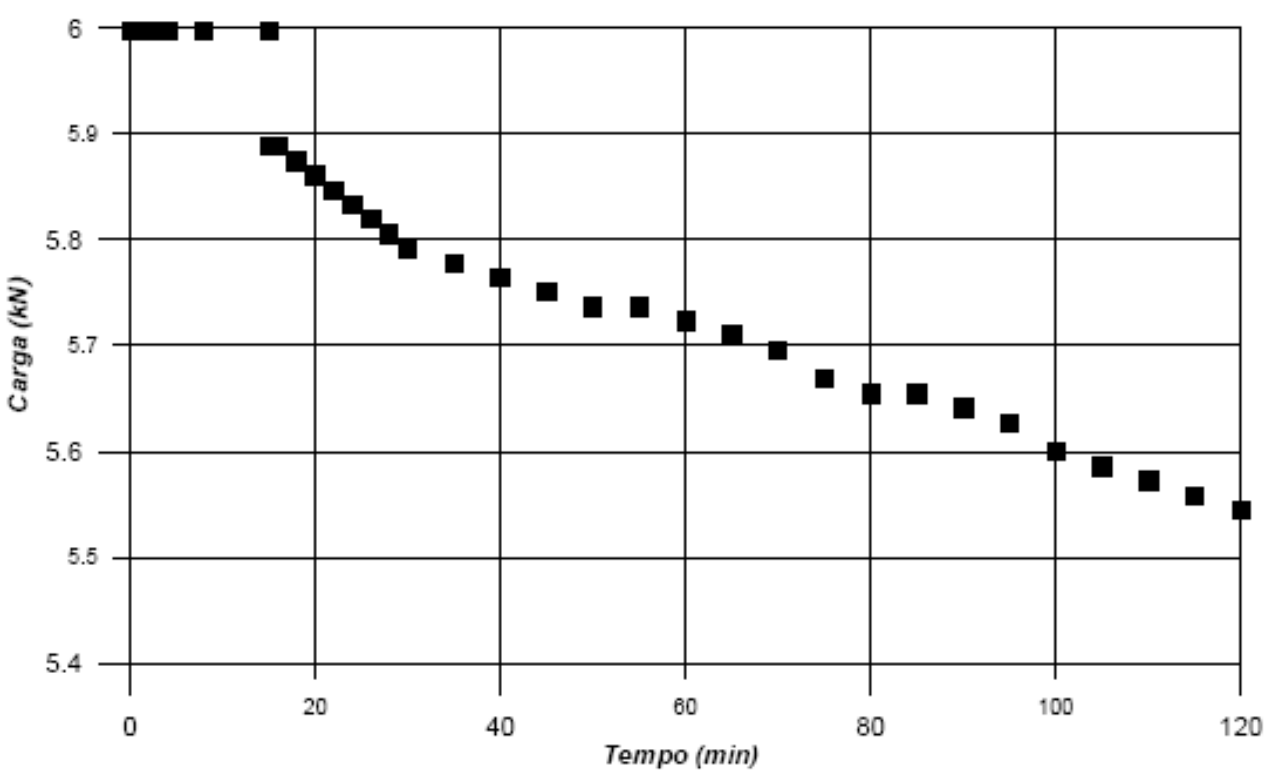

Figura 2.26 - Variação da carga com o tempo em um estágio (FRANCISCO, 2004) 
Benvenutti (2001) realizou oito provas de carga em 2 tubulões a céu aberto, no Campo Experimental de Fundações do Departamento de Geotecnia, cuja as curvas carga $\mathrm{x}$ recalque podem ser vistas nas Figuras 2.27 e 2.28. Os ensaios de 1 a 3 e 5 a 7 foram realizados pela modalidade QML e os ensaios 4 e 8 pela modalidade NML. A duração do carregamento nos dois casos era de 15 min, porém no NML assim que a carga atingia o valor previsto para o estágio, deixava-se de de fazer a reposição de carga, o que sempre possibilitou a estabilização de recalque e de carga.

Pode-se observar que nas Figuras 2.27 e 2.28 que a parte final das curvas carga $x$ recalque dos três ensaios $Q M L$, de um mesmo tubulão, constituem aproximadamente um único trecho reto. Porém, quando a modalidade é modificada para NML a diferença é considerável, para menos. Através da inclinação das retas tracejadas é possível presumir que a diferença apresenta uma tendência a aumentar com o acréscimo de carga.

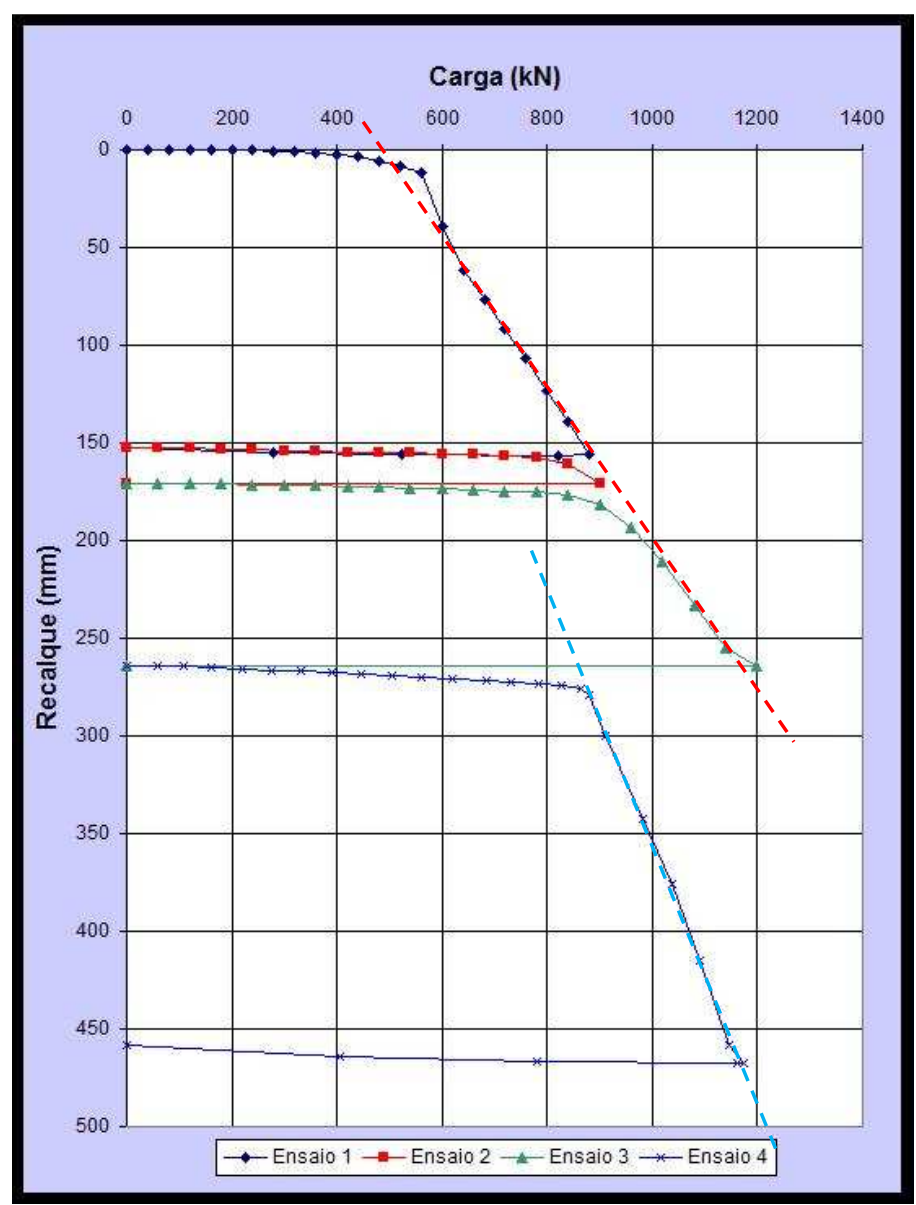

Figura 2.27 - Resultado da prova de carga do Tubulão 1, com o solo não inundado (BENVENUTTI, 2001) 


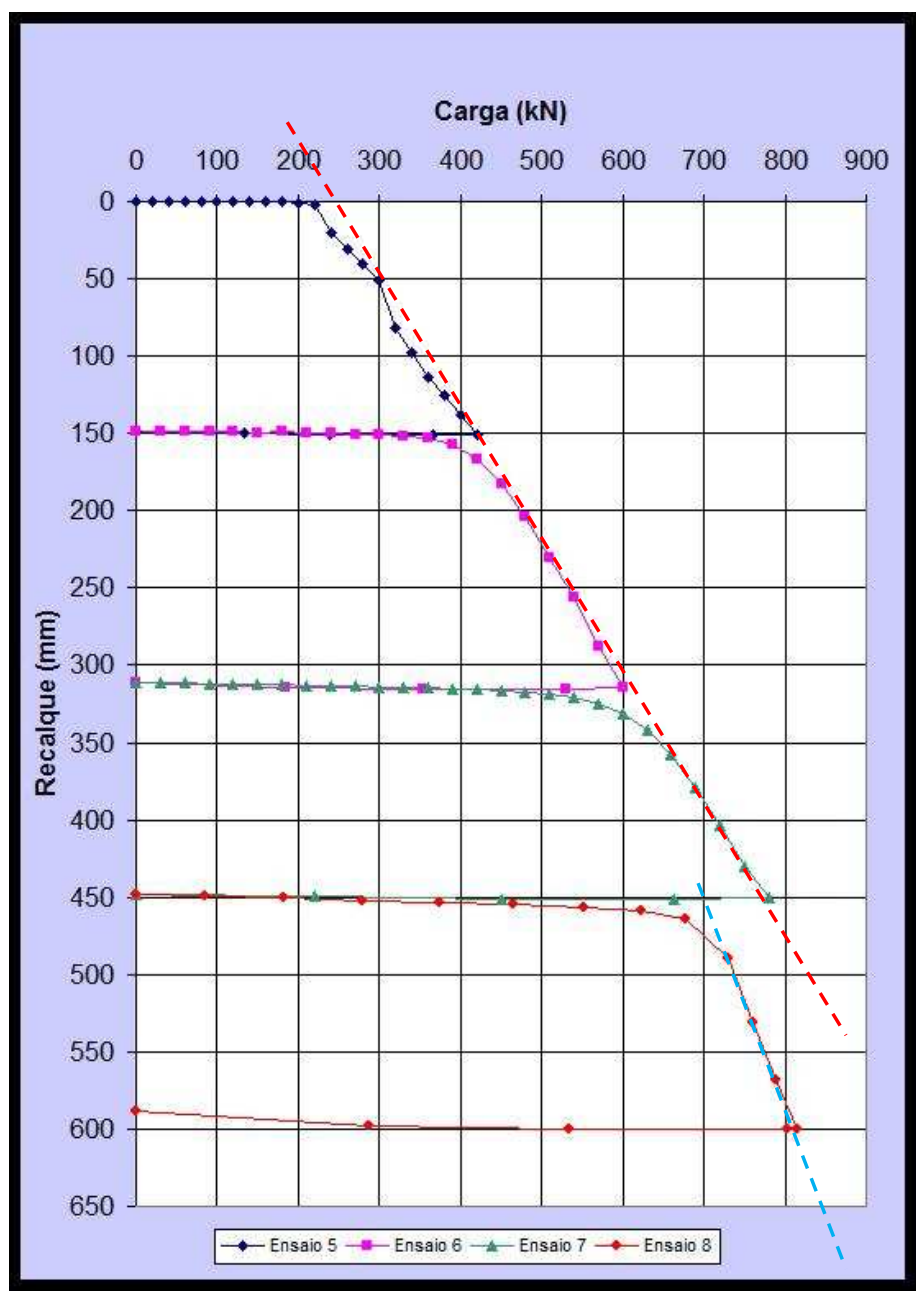

Figura 2.28 - Resultado da prova de carga do Tubulão 2, com o solo previamente inundado (BENVENUTTI, 2001) 


\subsection{Outros métodos}

\subsubsection{Método de deformação controlada - CRP}

O CRP (Constant Rate of Penetration) foi desenvolvido por Whitaker (1957) e consiste em ensaio pelo qual a placa é forçada a penetrar no solo a uma velocidade constante, normalmente $0,5 \mathrm{~mm} / \mathrm{min}$. As leituras de carga são feitas a cada dois minutos, sendo que a prova de carga e levada até que se atinja um recalque de ordem de 5 a $7,5 \mathrm{~cm}$, correspondendo a uma duração de duas a três horas.

O principal objetivo da prova de carga é determinar a capacidade de carga, mas na prática, a identificação da ruptura é geralmente difícil. Por isso, contudo Whitaker (1970) considera satisfatório adotar que a capacidade de carga seja a força necessária para a penetração de 10\% do diâmetro da placa, critério preconizado por Terzaghi (1942).

Para O IPT (1988) O CRP apresenta-se como o menos vantajoso, pois para a realização desse ensaio é imprescindível a manutenção de velocidade de penetração contínua, o que requer equipamentos especiais, como um macaco de fluxo constante de óleo.

Fellenius (1975) apresenta as curvas típicas de diversos carregamentos mostrada na Figura 2.29.

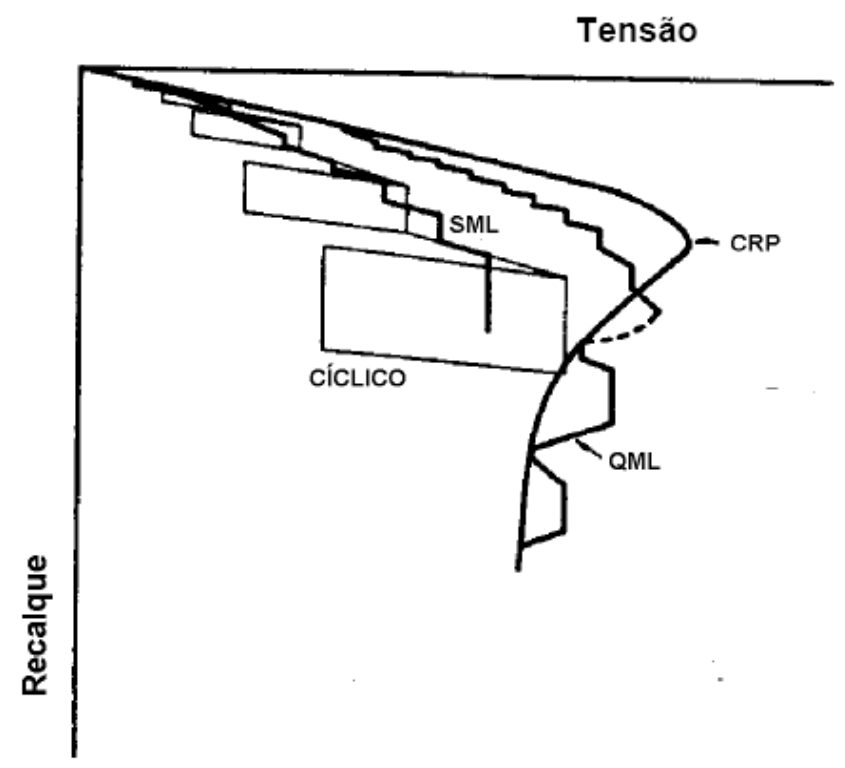

Figura 2.29 - Curvas tensão x recalque típicas dos diferentes tipos de ensaio (FELLENIUS, 1975) 
Prova de carga rápida com recalque estabilizado

\subsubsection{Prova de carga dinâmica - PDA}

A prova de carga dinâmica consiste em aplicar no topo de uma estaca um certo número de golpes por um martelo, e assim gerar ondas de deformação. O objetivo principal é obter uma avaliação da sua capacidade de carga através da aplicação da teoria da equação da onda. No Brasil, esta metodologia está normatizada pela NBR- 13208 - "Ensaio de Carregamento Dinâmico".

A prova de carga dinâmica foi desenvolvida originalmente para estacas cravadas, mais foi utilizada com sucesso em placas por Moraes (2005), com a realização de oito provas de carga dinâmica de energia crescente, conforme proposta de Aoki (1989), e quatro provas de carga estática QML.

Essas provas de carga foram realizadas em placas metálicas de $0,80 \mathrm{~m}$ de diâmetro no Campo Experimental de Fundações do Departamento de Geotecnia.

Nas Figuras de 2.30 a 33 são mostradas as curvas tensão $x$ recalque obtidas nas sucessivas provas de carga realizadas em quatro cavas. As curvas obtidas com as provas de carga dinâmica "encaixam" razoavelmente bem entre as duas provas de carga estática, o que indica a viabilidade da prova de carga dinâmica em placa. 


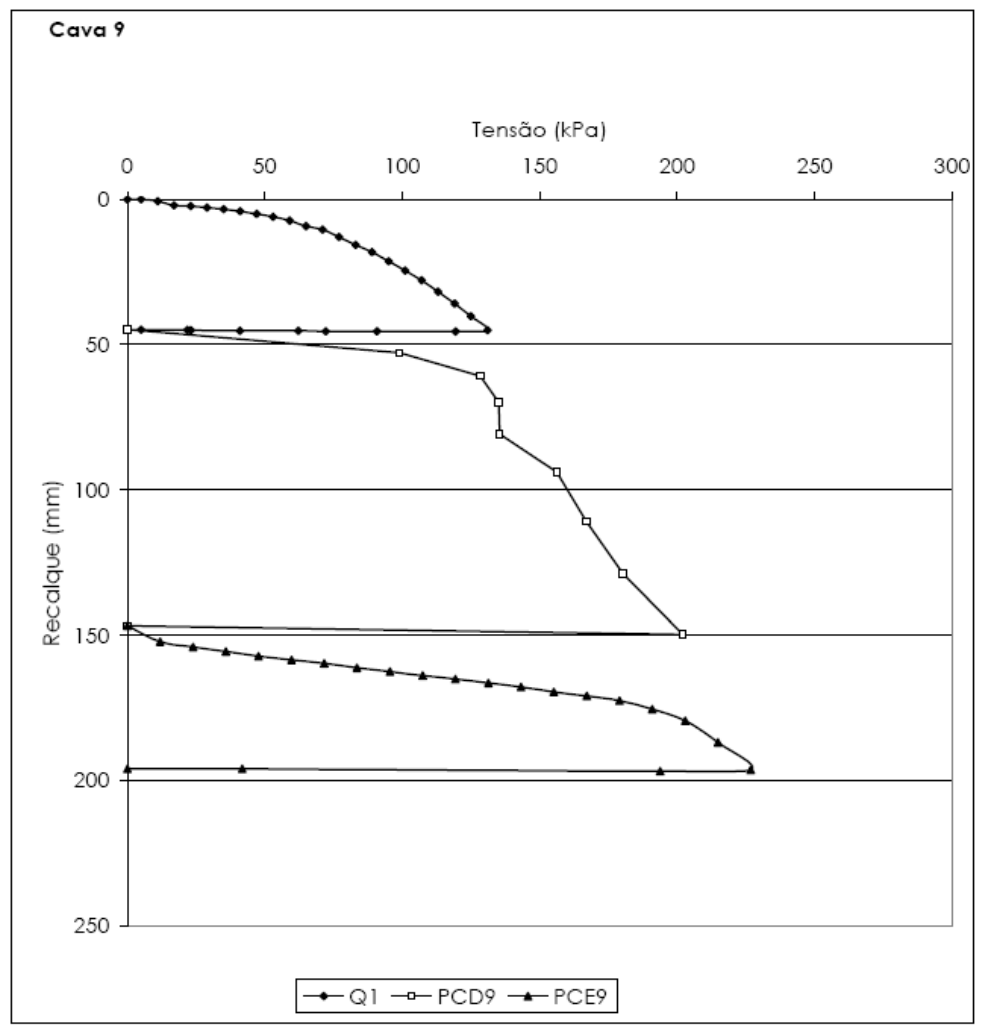

Figura 2. 30- Curvas tensão x recalque de três ensaios consecutivos: um dinâmico entre dois estáticos (cava 9, terreno não inundado) (MORAES, 2005)

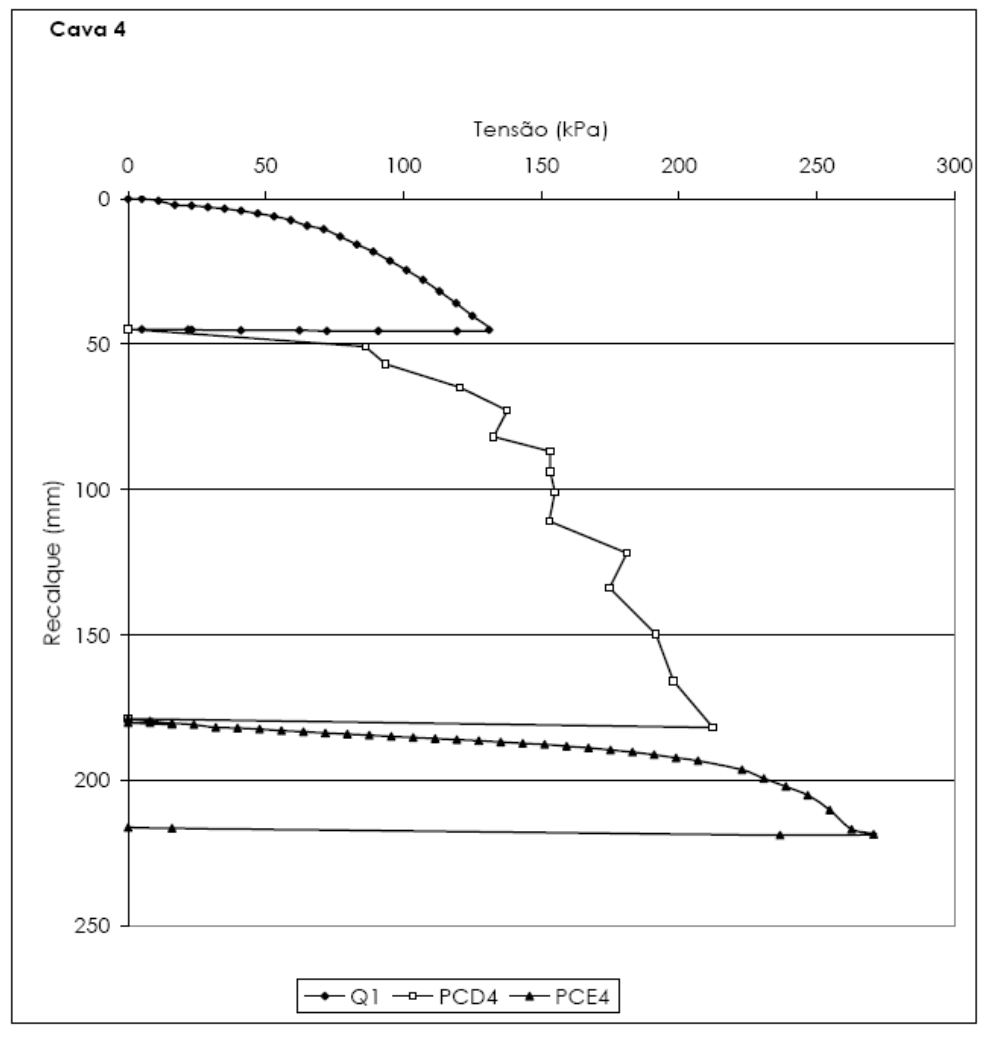

Figura 2. 31- Curvas $x$ tensão recalque de três ensaios consecutivos: um dinâmico entre dois estáticos (cava 4, terreno não inundado) (MORAES, 2005) 
Prova de carga rápida com recalque estabilizado

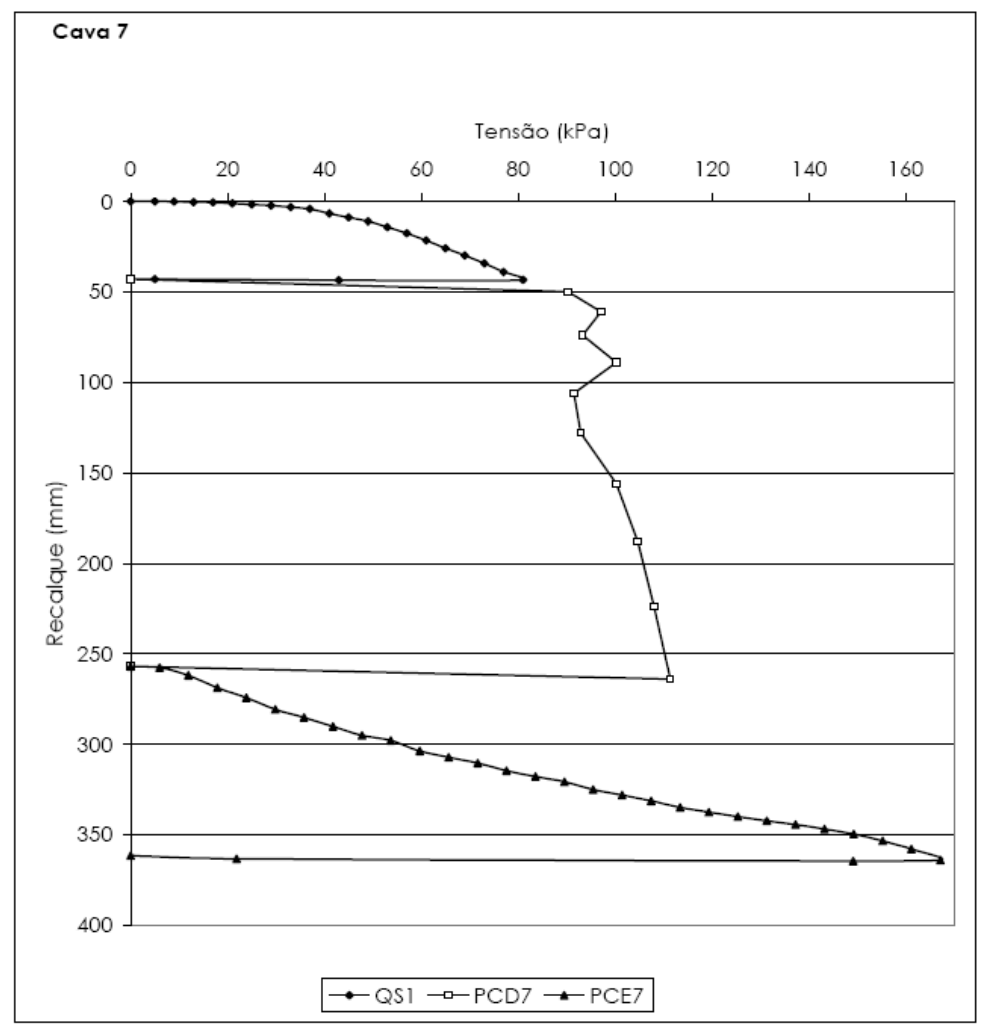

Figura 2. 32- Curvas x tensão recalque de três ensaios consecutivos: um dinâmico entre dois estáticos (cava 7, terreno inundado) (MORAES, 2005)

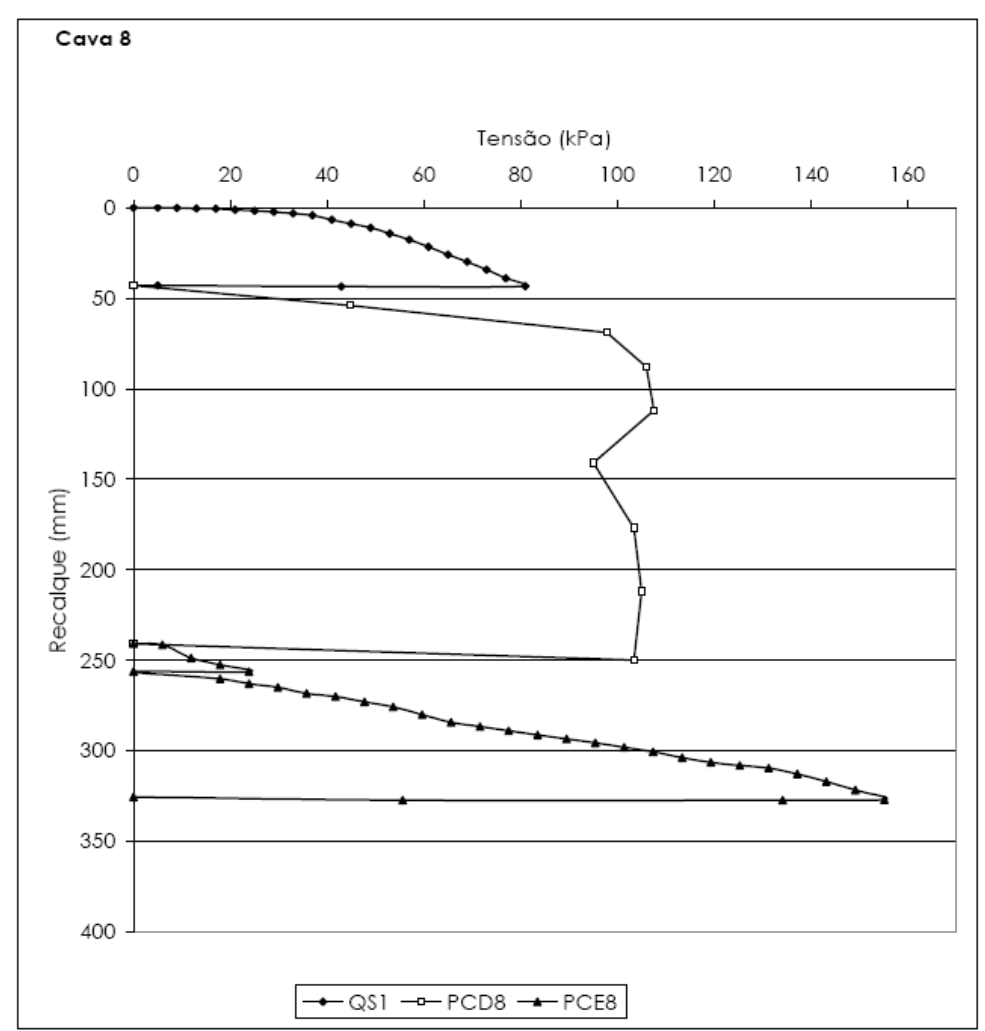

Figura 2. 33- Curvas tensão $x$ recalque de três ensaios consecutivos: um dinâmico entre dois estáticos (cava 8, terreno inundado) (MORAES, 2005) 


\subsection{Solos colapsíveis}

Certos tipos de solos não saturados, quando experimentam um aumento no seu teor de umidade, sofrem uma redução súbita de volume e de grandes proporções, sendo esta redução associada a uma perda rápida de resistência causando uma espécie de colapso da estrutura. Esses solos são denominados "solos colapsíveis".

Segundo Cintra (2004) há solos colapsíveis que, ao serem inundados, entram em colapso sem carregamento externo. É o caso, por exemplo, do loess russo. Entretanto, em solos colapsíveis brasileiros, o colapso só ocorre se a carga externa atingir um valor mínimo necessário, definido por Cintra (1995) como "carga de colapso". Portanto, para que estruturas edificadas em solos colapsíveis brasileiro sofram recalque de colapso é necessário que dois requisitos sejam satisfeitos: aumento do teor de umidade até um certo o valor critico, aquém da saturação completa, e atuação nas fundações, de uma carga, no mínimo, igual à carga de colapso.

Assim as fundações rasas, assentes em solos colapsíveis, podem apresentar durante algum tempo comportamento satisfatório, mas com a presença de água sofrem recalques diferenciais significativos.

\subsection{Influência da sucção na capacidade de carga}

Fredlund \& Rahardjo (1993) quantificaram o aumento da capacidade de carga com a sucção matricial, por meio da equação de Terzaghi (1943). A análise foi feita para sapatas corridas, de 0,5 a 1,0 metro de largura assentes a $0,5 \mathrm{~m}$ de profundidade. A Figura 2.34 ilustra a influência da sucção matricial na capacidade de carga. 
Prova de carga rápida com recalque estabilizado

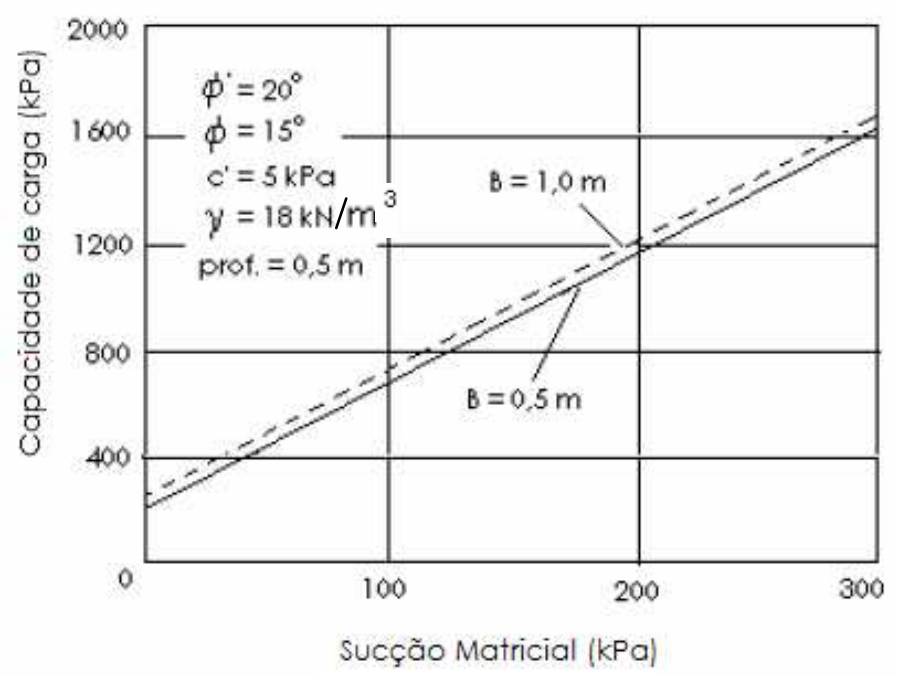

Figura 2.34 - Variação da capacidade de carga de sapatas corridas em função da sucção matricial (FREDLUND \& RAHARDJO, 1993)

Costa (1999) por meio de provas de carga em placa, assentes a 1,5 m de profundidade, realizadas no campo experimental de fundações da EESC/USP, comprovou experimentalmente que a sucção matricial possui grande influência na capacidade de carga. Conforme as Figuras 2.35 e 2.36, ensaios SML e QML, respectivamente, observa-se que o solo apresenta um aumento na rigidez provocado pelo crescimento da sucção. Quanto maior a sucção matricial do solo, maior a capacidade de carga.

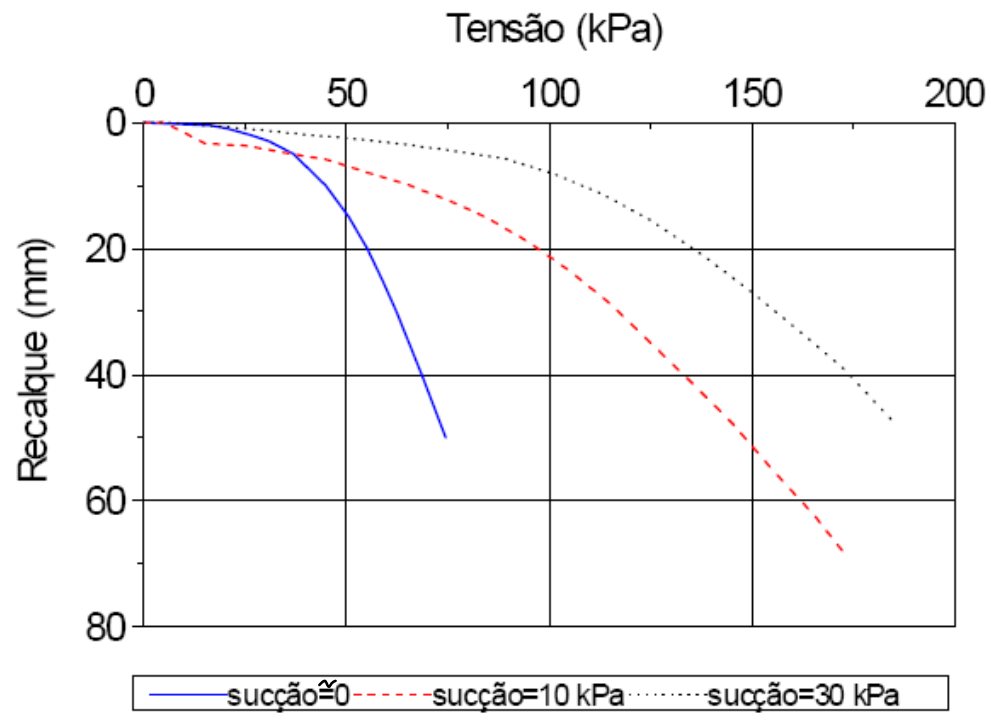

Figura 2.35 - Curva tensão x recalque dos ensaios SML realizados em diferentes níveis de sucção (Costa, 1999) 


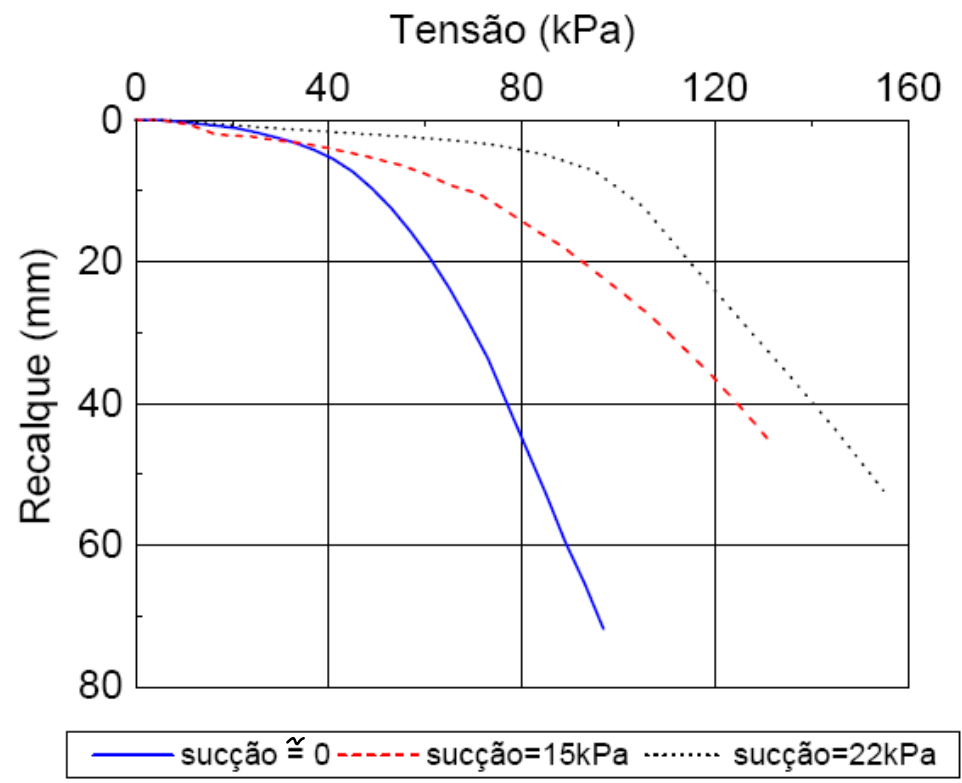

Figura 2.36 - Curva tensão x recalque dos ensaios SML realizados em diferentes níveis de sucção (Costa, 1999)

A partir das provas de cargas realizadas no Campo Experimental de Fundações por Costa (1999) e Macacari (2001), Menegotto (2004) adotou uma expressão matemática para a forma típica da curva tensão x recalque de ensaio de placa e realizou previsões da curva tensão $\times$ recalque para a placa de $0,80 \mathrm{~m}$, instalada em diferentes profundidades $(1,5,4,0 \mathrm{e}$ 6,0 m), com a variação da sucção no intervalo de 0 a 30 kPa. As Figuras 2.37 e 2.38 apresentam, respectivamente, o gráfico carga $x$ recalque e o gráfico capacidade de carga $x$ sucção. Pode-se notar um aumento significativo da capacidade de carga quando a sucção passa de 0 a $10 \mathrm{kPa}$. Após este nível de sucção, ocorrem acréscimos menos pronunciados de capacidade de carga, para os mesmos incrementos de sucção. Para as demais profundidades, 4,0 e 6,0 m, ocorre uma aumento praticamente constante da capacidade de carga com a sucção, inclusive de 0 a 10 kPa. 
Prova de carga rápida com recalque estabilizado

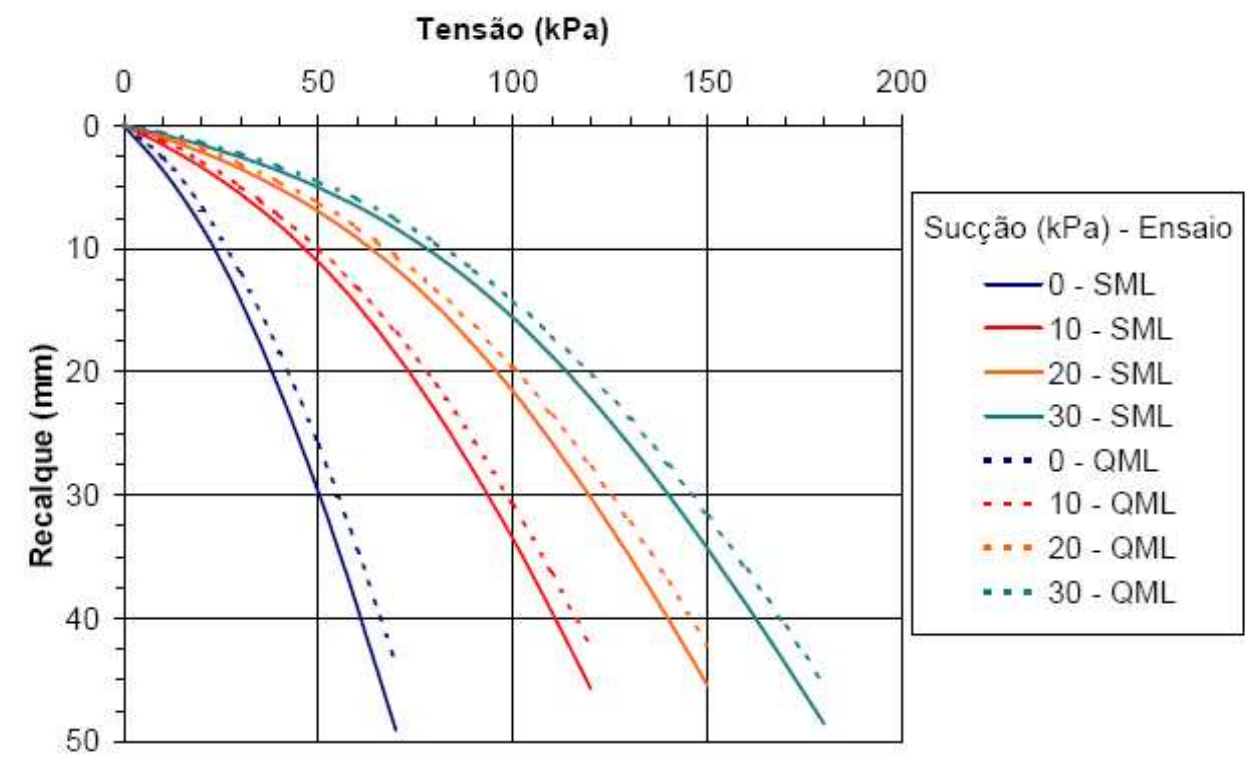

Figura 2.37 - Variação das curvas previstas de tensão x recalque com a sucção para ensaios de placa do tipo lento e rápido à $1,5 \mathrm{~m}$ de profundidade (MENEGOTTO, 2004)

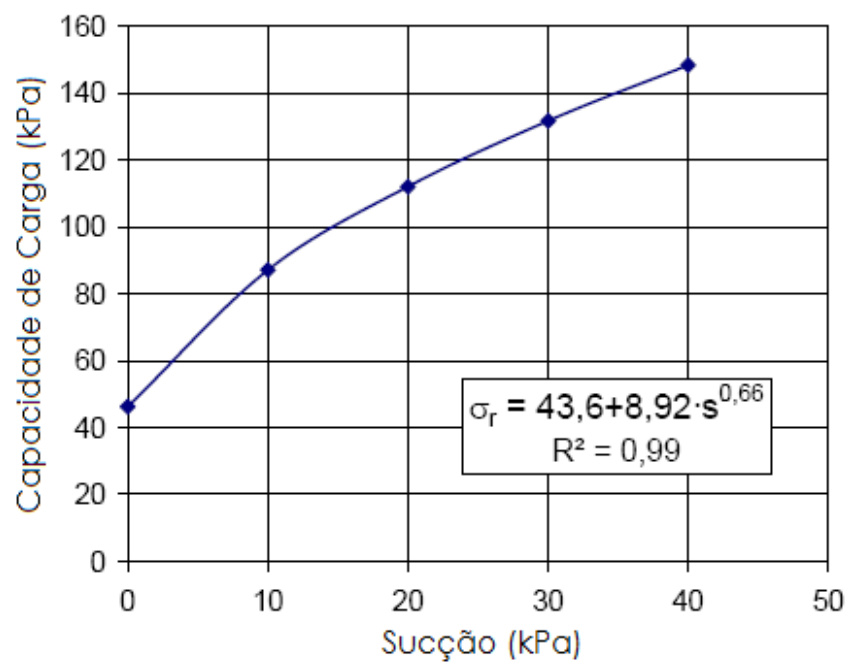

Figura 2.38 - Variação da capacidade de carga com a sucção (MENEGOTTO, 2004)

Vianna (2004) analisou o comportamento carga $x$ recalque de 14 provas de carga em placa com diâmetro de 0,20, 0,40, 0,80 e 1,50 m realizadas no campo experimental de fundações da EESC/USP, com diferentes níveis de sucção matricial e comprovou experimentalmente que a sucção matricial possui grande influência no comportamento solo-placa. São apresentadas na Figura 2.39 as curvas tensão x recalque obtidas nas provas de carga com a placa de $20 \mathrm{~cm}$. Os valores entre parênteses referem-se à sucção matricial média, 
em kPa. Os ensaios realizados com a placa de $20 \mathrm{~cm}$ apresentaram a maior redução devido ao colapso (cerca de $80 \%$ ).

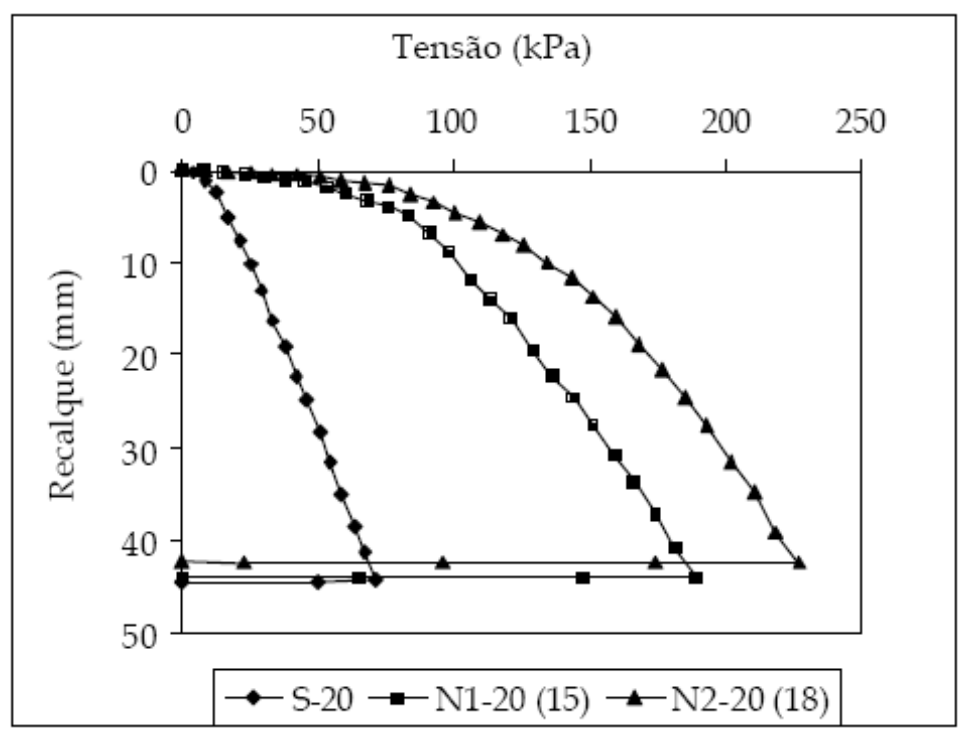

Figura 2.39 - Curvas de tensão x recalque dos ensaios para placa de 0,20 m (VIANNA, 2004)

Segundo Cintra (2004), na condição não inundada a curva carga recalque de uma prova de carga depende da sucção matricial atuante no solo no início do ensaio. Assim, para diferentes valores de sucção, diferentes curvas carga $x$ recalque serão obtidas, como pode se ver na Figura 2.40. Para altos valores de sucção matricial, diminui-se o valor de deformabilidade e aumenta-se a capacidade de carga. Para valores mais baixos de sucção matricial, aumenta-se a deformabilidade e diminui-se a capacidade de carga.

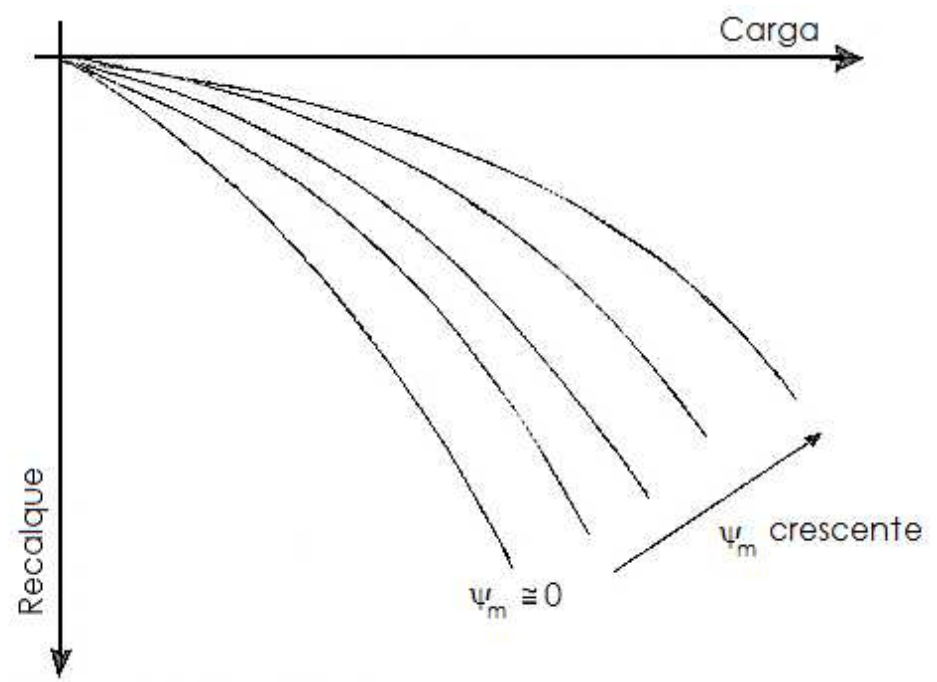

Figura 2.40 - Família de curvas carga recalque para diferentes valores de sucção matricial média no solo (CINTRA, 2004) 
Prova de carga rápida com recalque estabilizado

\subsection{Tensiômetro}

Segundo SOCCOL et al. (2005) o tensiômetro, geralmente, consiste de: um tubo de PVC, cheio com água, com uma cápsula de cerâmica fixada em sua extremidade inferior, uma vedação na parte superior do tubo, e um indicador de vácuo, o qual pode ser um vacuômetro de coluna de mercúrio (Figura 2.41 A), ou um vacuômetro metálico tipo Bourdon ou digital (Figura 2.41 B), fixo ou móvel, também conhecido como tensímetro de punção (Figura $2.41 \mathrm{C}$ ).

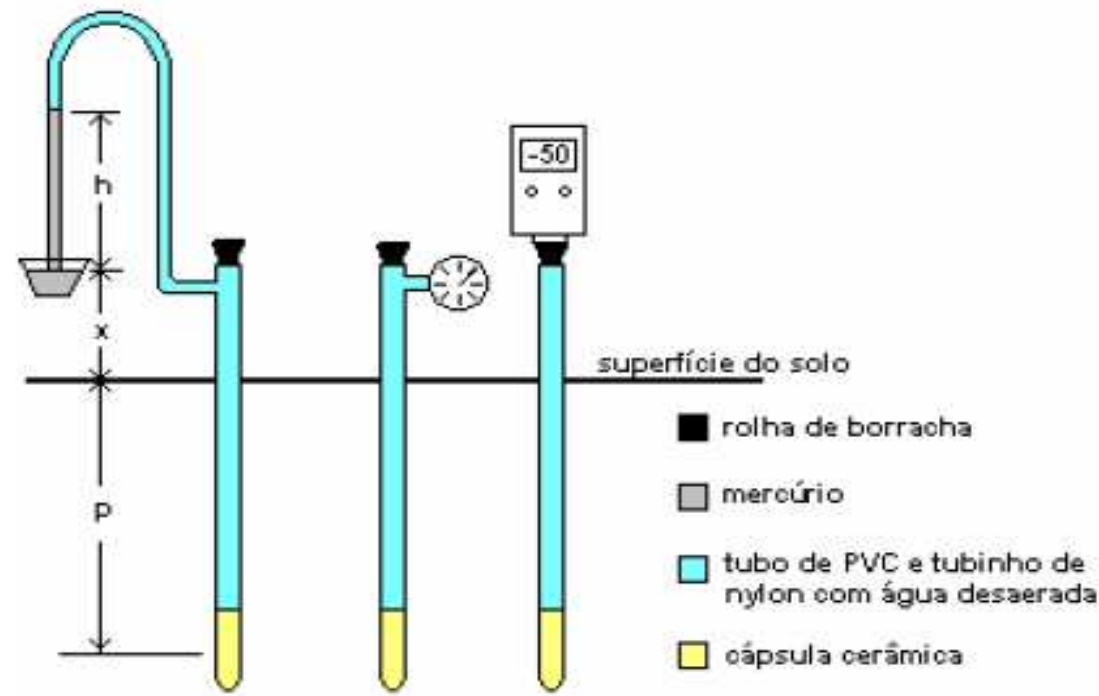

A B C

Figura 2. 41 - Tipos mais comuns de tensiômetro: de coluna de mercúrio (A), com vacuômetro (B) e com transdutor de pressão ou tensímetro (C) (Serviço Brasileiro de Respostas Técnicas - SBRT)

Conforme COELHO (2004) o princípio de funcionamento do tensiômetro baseia-se na formação do equilíbrio entre a solução do solo e a água contida no interior do aparelho. O equilíbrio ocorre quando a cápsula porosa entra em contato com o solo e a água do tensiômetro entra em contato com a água do solo. Caso a água do solo esteja sob tensão, ela exerce uma sucção sobre o instrumento, retirando água deste, fazendo com que a pressão interna diminua. Como o instrumento é vedado, ocorre a formação do vácuo; a leitura dessa pressão negativa fornece o potencial matricial da água no solo. 
Para WOLLE \& CARVALHO (1988) o tensiômetro deve suprir as necessidades de grande parte dos trabalhos de engenharia. Isto é afirmado quer em termos de tempo de resposta como na faixa de trabalho.

CONCIANI (1997) afirma que o tensiômetro é praticamente o único equipamento capaz de medir de forma direta a sucção matricial no solo. Segundo o autor o princípio de funcionamento é simples, porém há restrições ao funcionamento dos tensiômetros. A restrição mais séria neste caso é a pressão de cavitação da água, portanto o emprego dos tensiômetros está restrito a sucções inferiores a 100 kPa. 
Prova de carga rápida com recalque estabilizado

\section{MATERIAIS E MÉTODO}

\subsection{Amostras Indeformadas}

Foram coletadas amostras indeformadas no Campus II da USP em São Carlos.

Para o material do mesmo local SOTO (2004) realizou ensaios de laboratórios em amostras indeformadas. Foram determinados os índices físicos, a composição granulométrica, a massa especifica seca máxima e a umidade ótima, quando compactados pelo ensaio de Próctor Normal, cujos resultados constam na Tabela 3.1. A curva granulométrica do material pode ser observada na Figura 3.1.

Tabela 3. 1- Resultados de caracterização e compactação do solo (SOTO, 2004)

\begin{tabular}{|c|c|c|}
\hline Descrição & Unid & $\begin{array}{l}\text { Campus II } \\
\text { Indeformado }\end{array}$ \\
\hline Areia Grossa & $\%$ & 4 \\
\hline Areia Média & $\%$ & 31 \\
\hline Areia Fina & $\%$ & 30 \\
\hline Silte & $\%$ & 5 \\
\hline Argila & $\%$ & 30 \\
\hline$\rho_{\mathrm{s}}$ & $\mathrm{g} / \mathrm{cm}^{3}$ & 2,75 \\
\hline$\rho_{\mathrm{d}}$ & $\mathrm{g} / \mathrm{cm}^{3}$ & 1,44 \\
\hline w & $\%$ & 16,1 \\
\hline$W_{L}$ & $\%$ & 26 \\
\hline$w_{p}$ & $\%$ & 19 \\
\hline$\rho_{\mathrm{d}}($ máximo) - Próctor normal & $\mathrm{g} / \mathrm{cm}^{3}$ & 1,75 \\
\hline w(ótima) - Próctor normal & $\%$ & 16,4 \\
\hline e & & 0,91 \\
\hline $\mathrm{Sr}_{\mathrm{r}}$ & $\%$ & 48,8 \\
\hline $\begin{array}{c}\text { Classificação Granulométrica } \\
\text { (ABNT) }\end{array}$ & & $\begin{array}{l}\text { Areia média a fina } \\
\text { argilosa, marrom }\end{array}$ \\
\hline
\end{tabular}




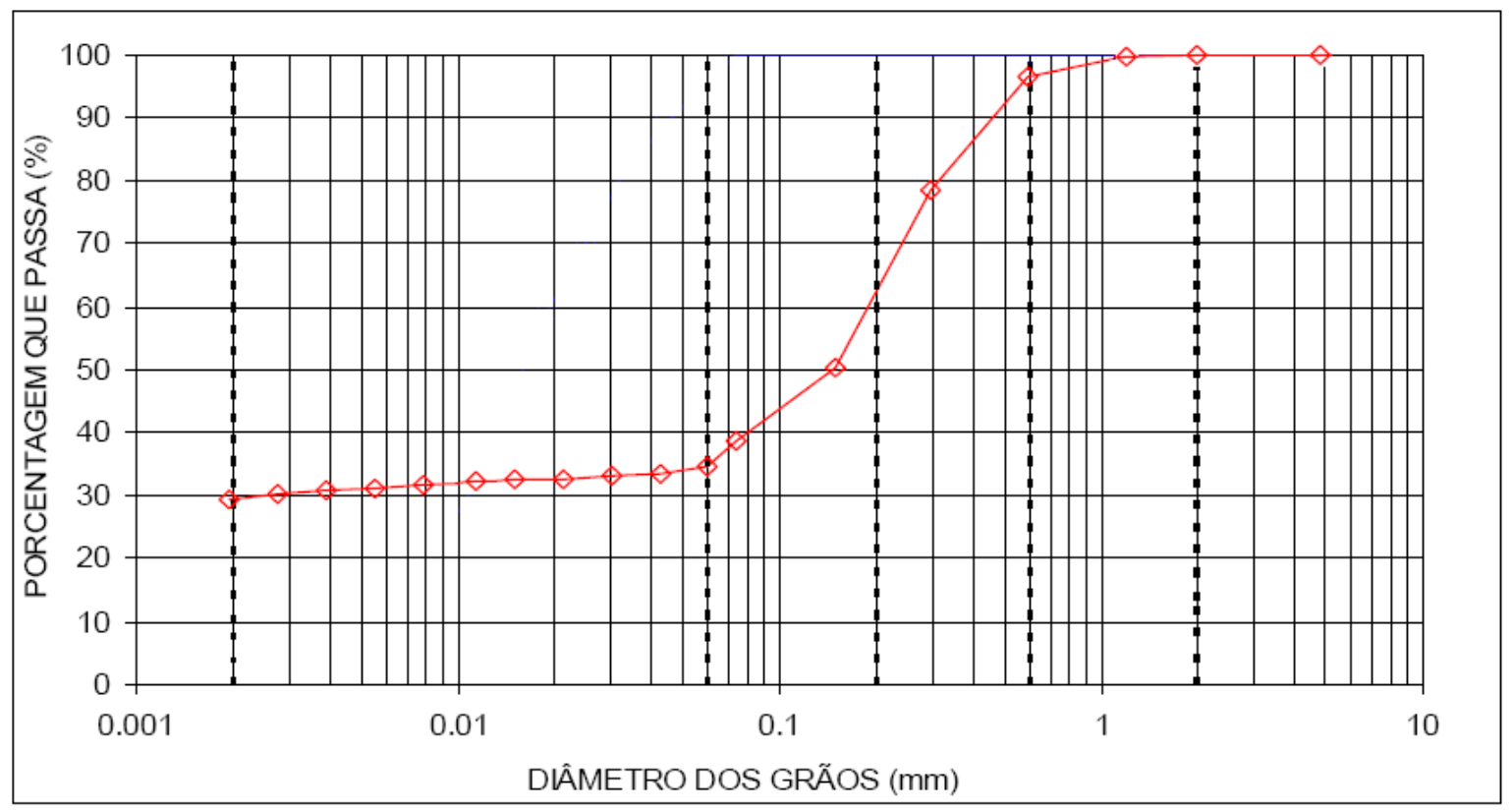

Figura 3. 1 - Curva granulométrica do solo ensaiado (modificado de SOTO, 2004)

SOTO (2004) ainda apresentou os resultados experimentais de retenção de água, obtidos pelo processo de secagem, e representados através da relação entre a sucção matricial e a umidade volumétrica. A figura 3.2 mostra os dados obtidos valendo-se dos métodos de translação de eixos (TE), do papel filtro (PF), do osmótico (MO), do tensiômetro de alta capacidade (TAC) e do funil com placa porosa (FPP). Na figura 3.3 são mostradas as imagens por microscopia eletrônica de varredura desse solo.

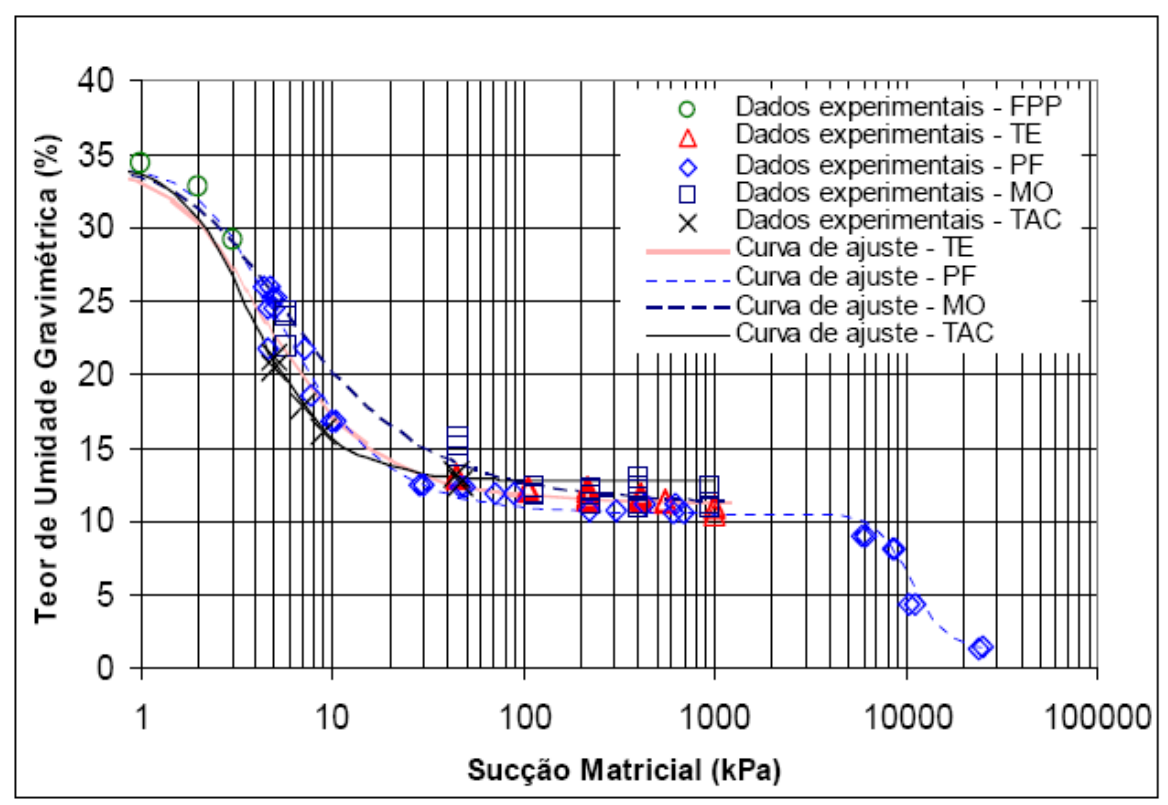

Figura 3.2 - Curvas de retenção obtidas por diferentes métodos para o solo estudado (SOTO, 2004) 

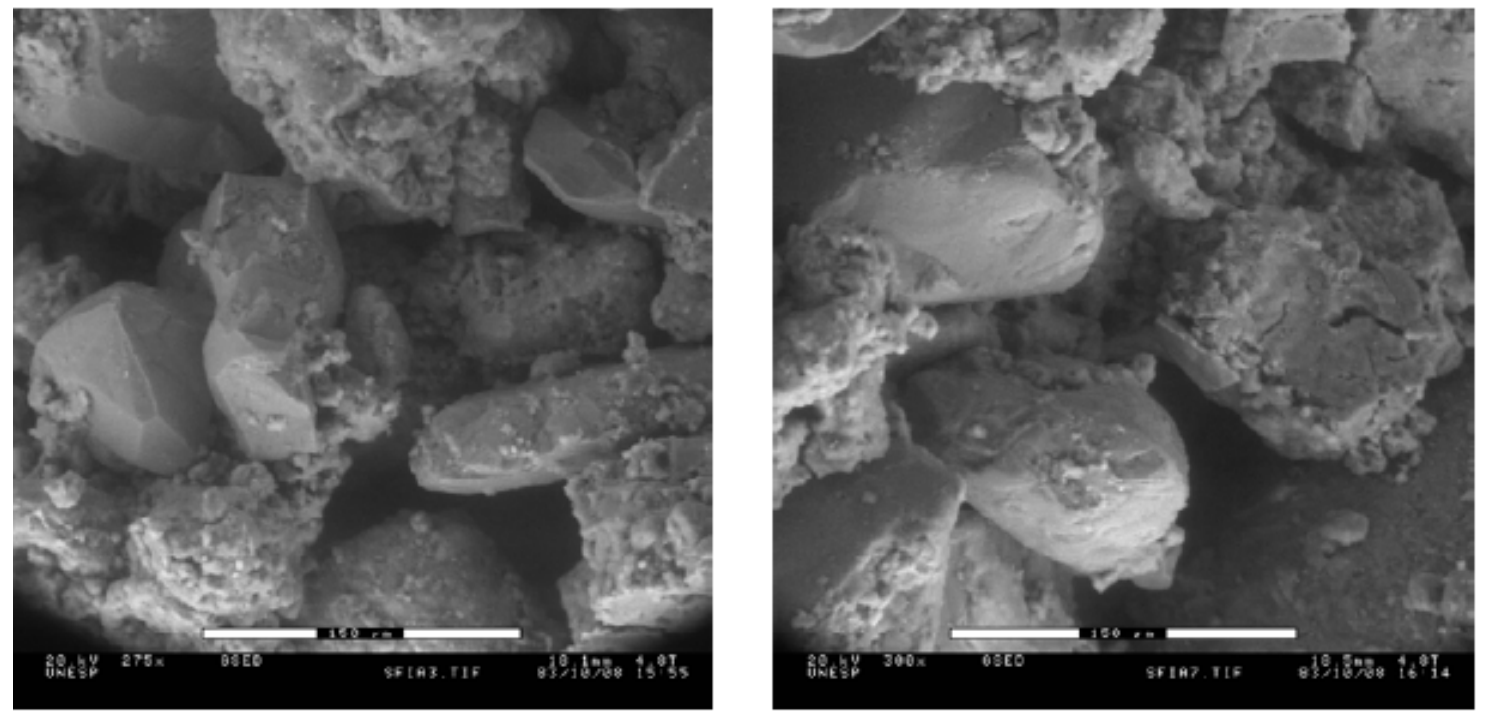

Figura 3.3 - Imagens do solo estudado provenientes da microscopia eletrônica de varredura a) aproximação de 275 vezes; b) aproximação de 300 vezes (SOTO, 2004)

Para esta pesquisa, a retirada das amostras foi feita num talude de corte do terreno natural. Antes, era escavada a camada superficial de 30 a $40 \mathrm{~cm}$. A retirada em forma de blocos foi feita através de moldes prismáticos de seção quadrada conforme Figura 3.4, com $30 \mathrm{~cm}$ de altura e $30 \mathrm{~cm}$ de lado e com $3 \mathrm{~mm}$ de espessura. A profundidade de retirada dos mesmos variou entre $0,30 \mathrm{~m} \mathrm{e} \mathrm{1,10} \mathrm{m}$.

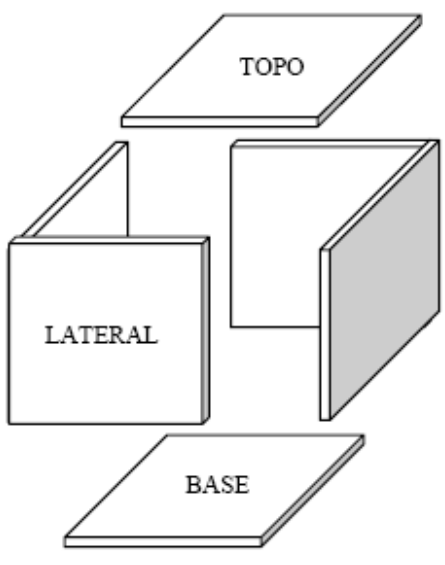

(a)

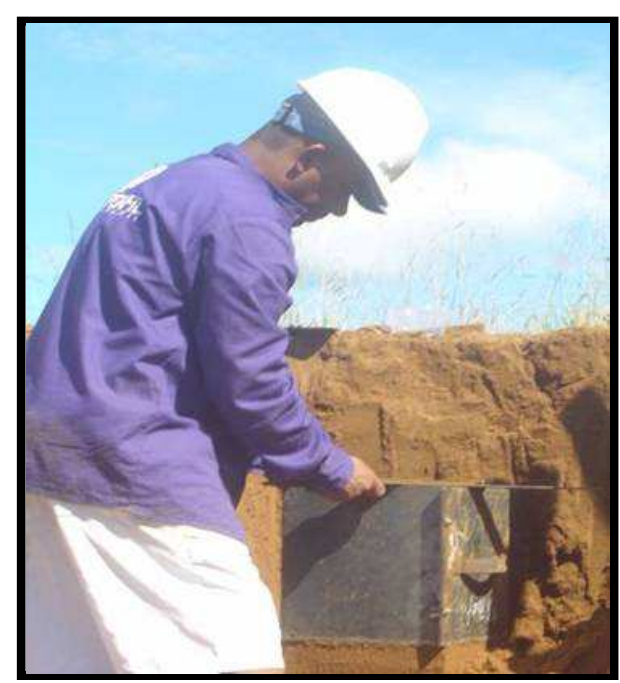

(b)

Figura 3.4 - (a) esquema de montagem da caixa (b) retirada das amostras no campo 
Ainda no campo, a amostra era desmoldada e colocada sobre uma chapa metálica de $32 \times 32 \mathrm{~cm}^{2}$ com $3 \mathrm{~mm}$ de espessura que, por sua vez, era colocada sobre forma de madeira com $35 \times 35 \mathrm{~cm}^{2}$ para transporte, conforme a Figura 3.5 .

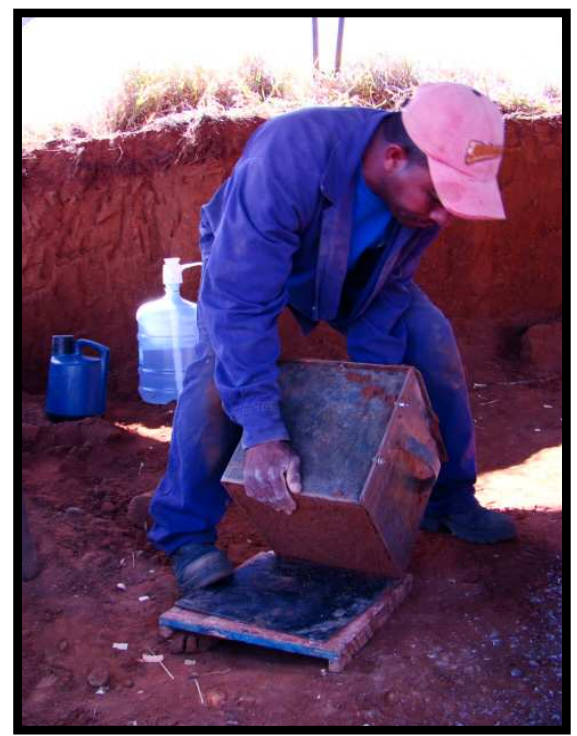

Figura 3. 5 - Amostra colocada sobre chapa metálica e chapa de madeira

A amostra recebia a primeira camada de parafina para conservar sua umidade "in loco". Para a preservação da estrutura, o bloco era envolvido com um tecido poroso conforme a Figura 3.6 e, em seguida, aplicada uma segunda camada de parafina. Todas as amostras eram etiquetadas e armazenadas na câmara úmida conforme a Figura 3.7, até a data de sua utilização.

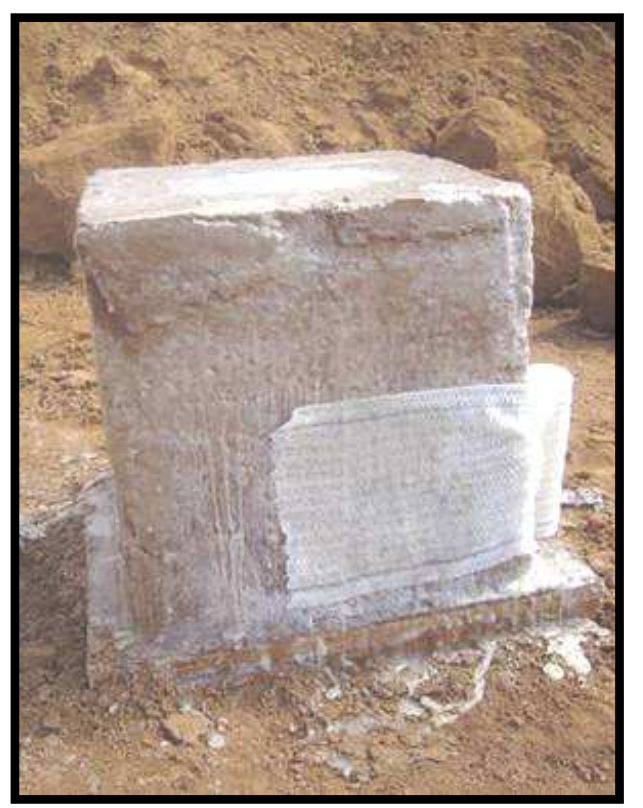

Figura 3.6- Bloco sendo envolvido em tecido poroso 
Prova de carga rápida com recalque estabilizado

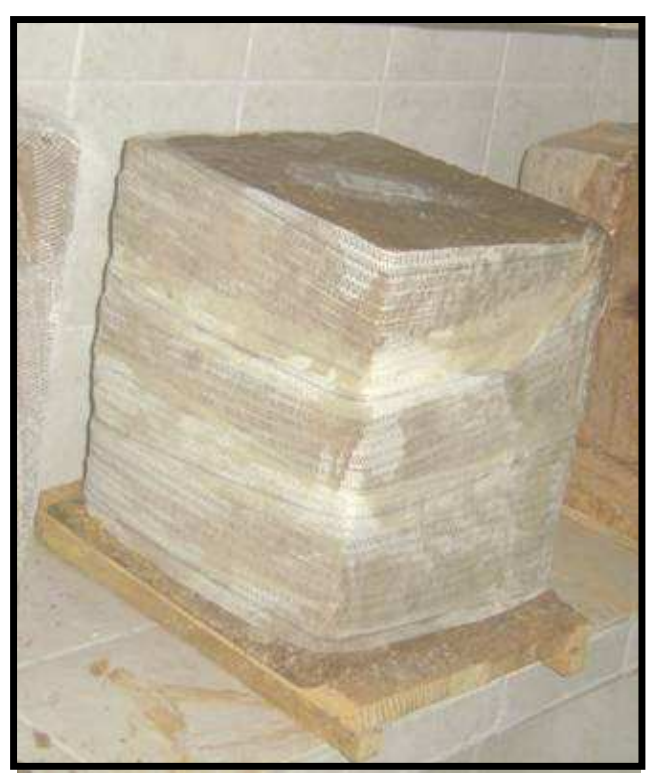

Figura 3.7 -Bloco armazenado em câmara úmida

\subsection{Bloco}

Os blocos indeformados não eram modificados antes do ensaio, de modo que permaneciam com seção quadrada com $30 \mathrm{~cm}$ de altura e $30 \mathrm{~cm}$ de lado. A chapa metálica que era colocada sob o bloco para transporte, do campo para o laboratório, era conduzida juntamente com o bloco para a prensa, para não haver deformação na base do bloco.

\subsection{Tubo tensiométrico e Tensímetro}

A sucção exerce grande influência na capacidade de carga de fundações em solos não saturados. Por isso, no momento da realização do ensaio foi imprescindível a monitoração da sucção matricial nos blocos. Essa medida era feita através de tensiômetros, que são compostos pelo tubo tensiométrico e o tensímetro.

O tubo tensiométrico é constituído por um tubo plástico, de comprimento $20 \mathrm{~cm}$, em cuja extremidade inferior há uma cápsula porosa. É fechado hermeticamente na extremidade superior por uma rolha de borracha siliconada conforme Figura 3.8. Foi necessária a fabricação do tubo tensiométrico porque deveria ter uma área de seção transversal pequena para não danificar a estrutura do bloco. 


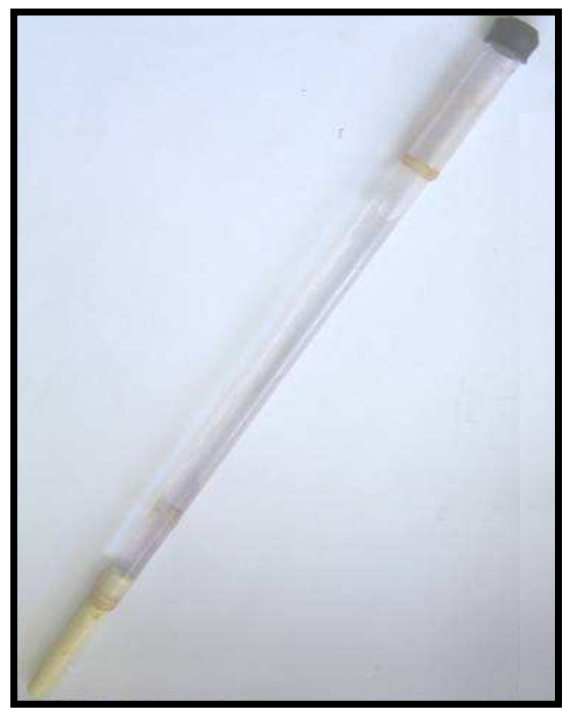

Figura 3.8 - Tubo tensiométrico

Com o auxílio do tensímetro, conforme a Figura 3.9, é possível fazer as leituras da tensão de sucção matricial da água no solo diretamente no tubo tensiométrico, puncionando, por meio de uma agulha especial, a rolha de borracha siliconada.

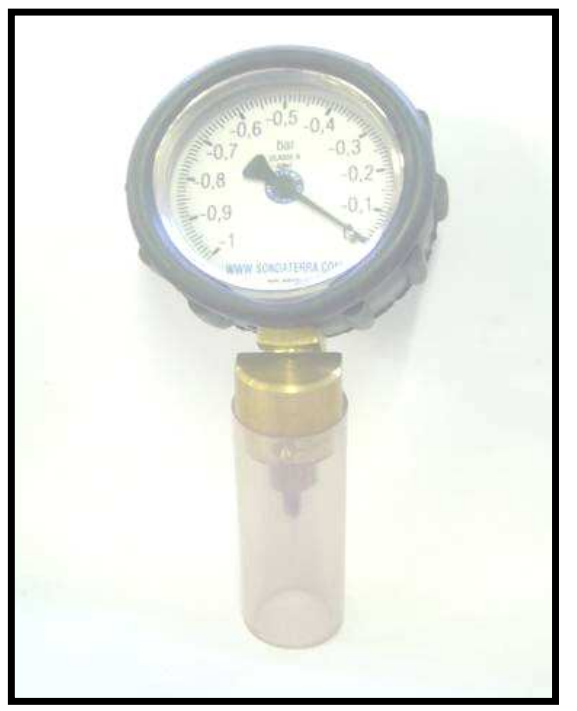

Figura 3.9 - Tensímetro

Antes da realização das provas de carga eram instalados os tubos tensiométricos, com no mínimo 12 horas de antecedência para a medida de sucção. Para sua instalação era necessário um pré-furo com $9 \mathrm{~cm}$ de profundidade. Em cada bloco eram instalados três tubos tensiométricos, conforme a Figura 3.10. 


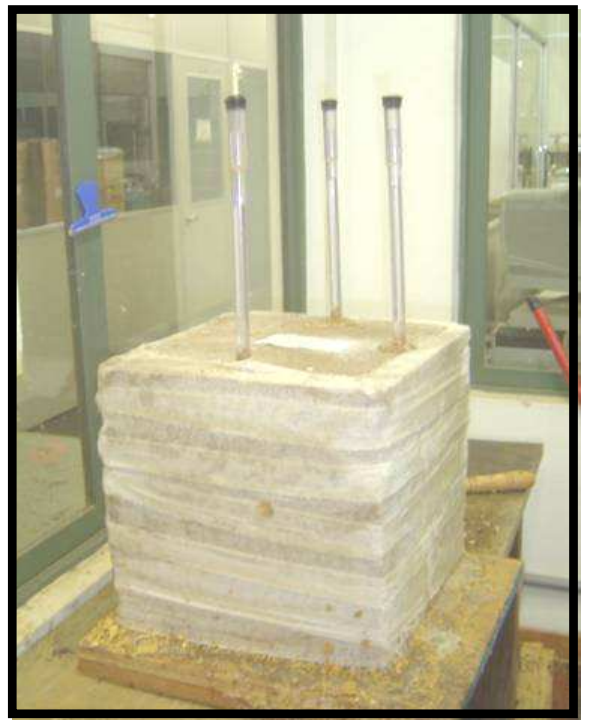

Figura 3.10- Tubos tensiométricos instalados no bloco

\subsection{Placa}

De acordo com Vesic (1965), apud Cintra (1987), os modelos de fundações em solos arenosos devem ter um diâmetro mínimo de 38,1 mm (ou em torno do diâmetro do cone holandês) para fornecer dados significativos. Por isso, adotou-se diâmetro igual a $40 \mathrm{~mm}$ para a placa, a qual foi desenvolvida com uma "aba" para que o extensômetro digital e analógico pudesse fazer as leituras de recalque conforme as Figuras 3.11 e 3.12, pois a célula de carga da prensa possui diâmetro igual a 60 mm, o que impediria a instalação do relógio comparador verticalmente.

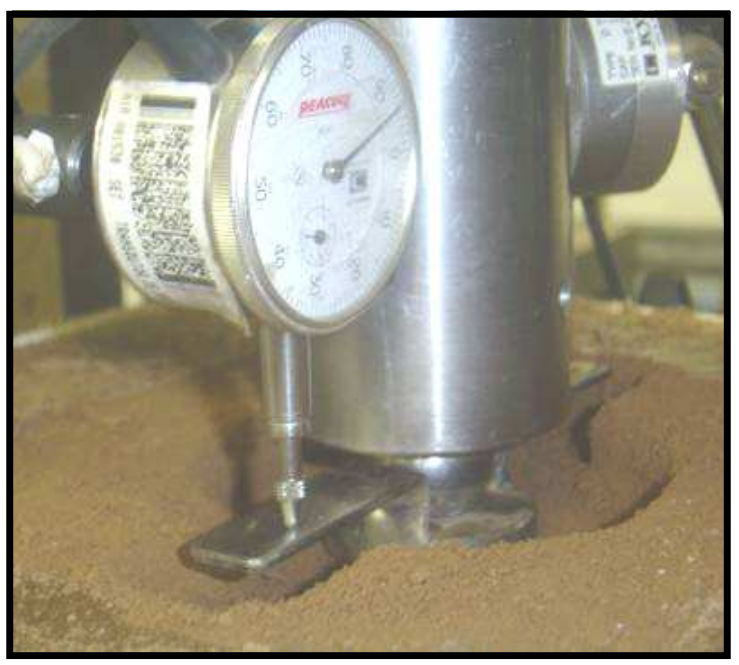

Figura 3.1 1- Vista da placa de 40 mm com "aba" 

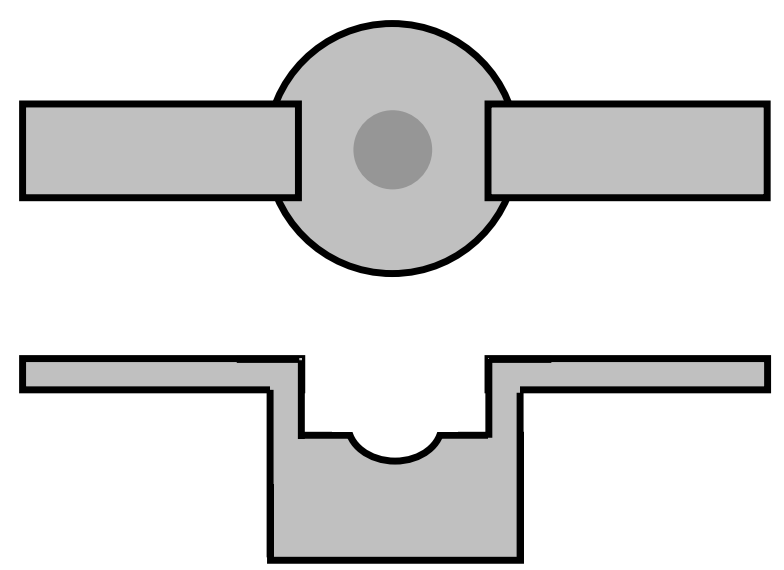

Figura 3.12 - Esquema da placa vista superior e vista lateral

\subsection{Prensa}

A prensa utilizada, mostrada na Figura 3.13, foi a MTS-815 - Rock Mechanics Testing System do Laboratório de Mecânica das Rochas do Departamento de Geotecnia da Escola de Engenharia de São Carlos.

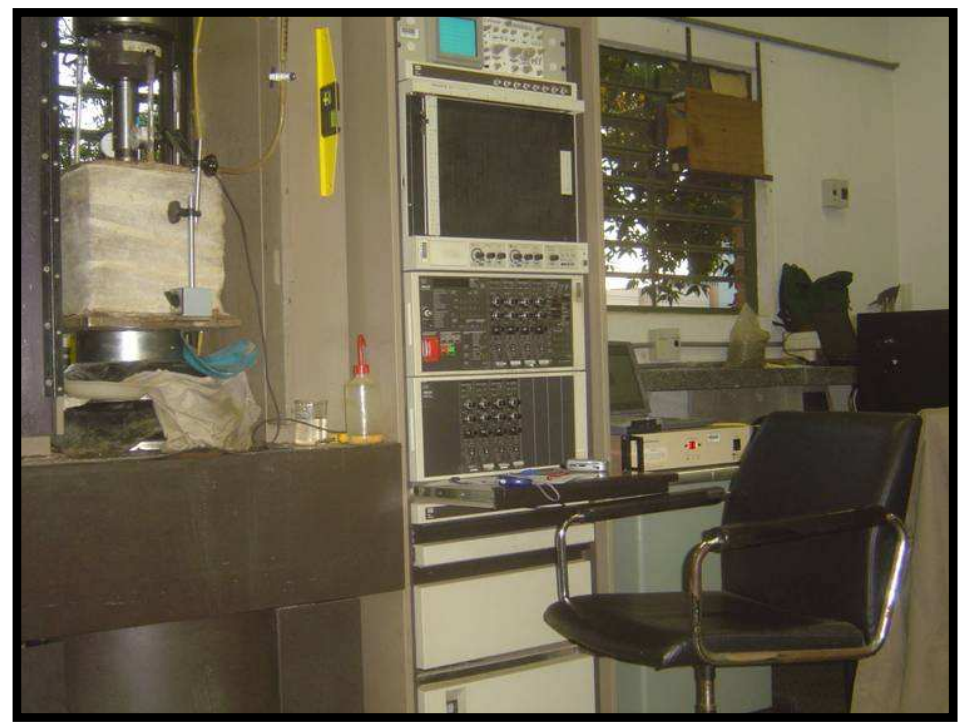

Figura 3.13 - Vista geral da prensa

Os deslocamentos da placa eram medidos por dois extensômetros digital e analógico, mostrados na Figura 3.14, que eram ligados ao sistema de aquisição de dados. Os valores de deslocamento e de força exercida pela prensa eram adquiridos a cada 30 segundos pelo sistema e enviados ao computador, conforme as Figuras 3.14 e 3.15. 
Prova de carga rápida com recalque estabilizado

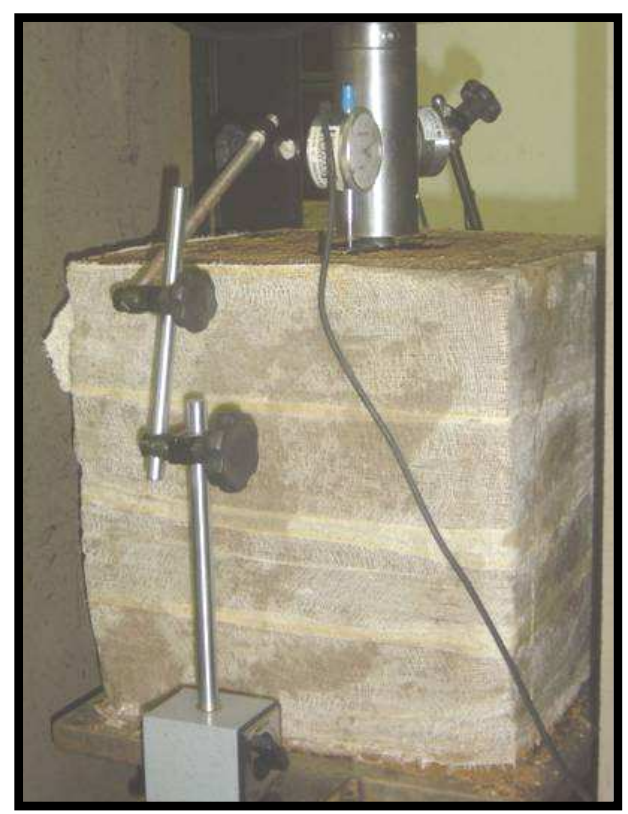

Figura 3.14 - Bloco com os relógios comparadores

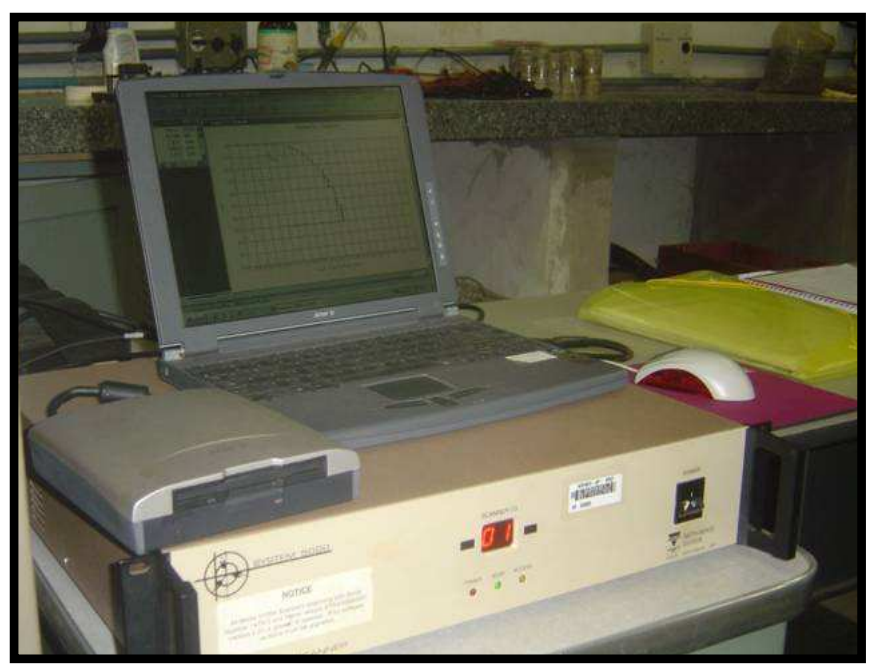

Figura 3.15 - Sistema de aquisição de dados. 


\section{ENSAIOS REALIZADOS E RESULTADOS}

Foram realizadas provas de carga em quatro condições de sucção matricial no solo: a) praticamente zero (solo inundado); b) $15 \mathrm{kPa}$; c) $35 \mathrm{kPa}$ e d) $45 \mathrm{kPa}$. Para cada condição, foram empregadas três modalidades de ensaio: a) lenta (SML); b) rápida (QML) e c) método do equilíbrio (NML).

\subsection{Prova de Carga Lenta - SML}

Para a realização da prova de carga lenta foi seguido o procedimento descrito na NBR 6489/84. Através de ensaios preliminares, para verificar a utilização pioneira da prensa nesse caso, estimou-se a capacidade de carga do sistema e planejou-se o carregamento em 10 estágios. Nas Figuras 4.1 a 4.4 são exibidas as curvas tensão x recalque relativas à série de oito provas realizadas pelo SML, agrupadas de acordo com a sucção matricial.

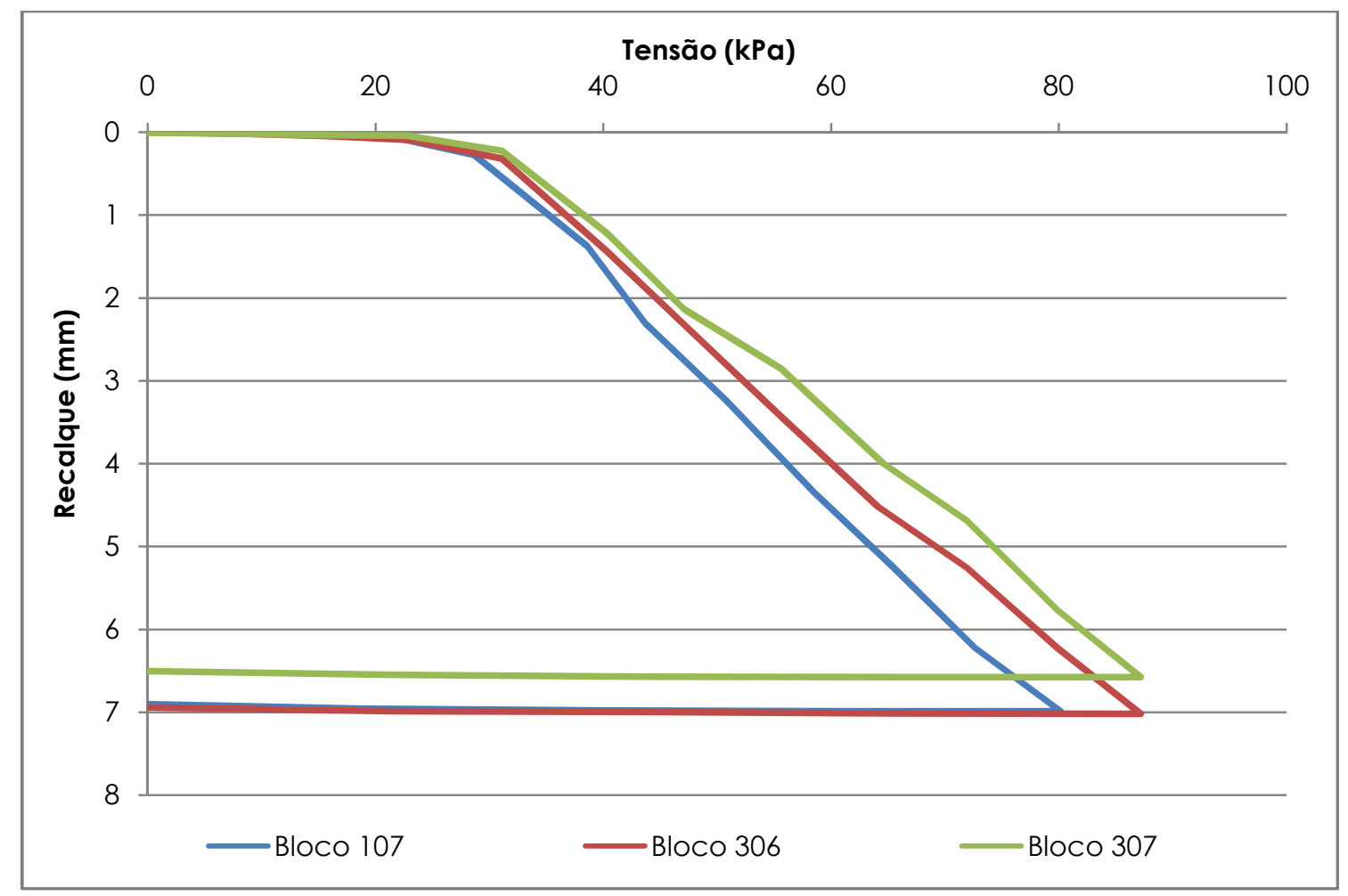

Figura4. 1- Curvas tensão $\times$ recalque dos ensaios SML ( $\psi m \cong 0)$ 
Prova de carga rápida com recalque estabilizado

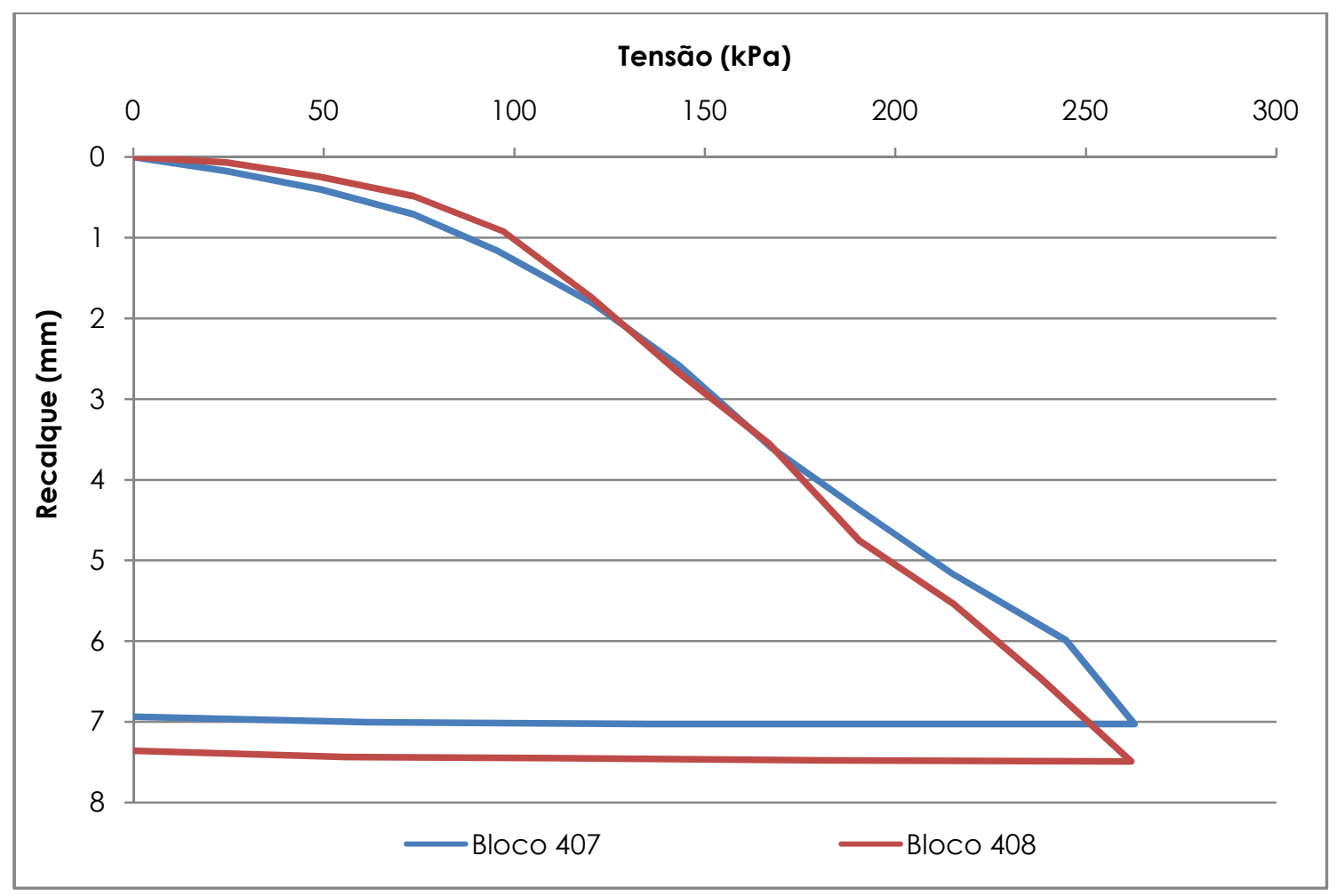

Figura4. 2 - Curvas tensão $\times$ recalque dos ensaios SML $\left(\psi_{m}=10 \mathrm{kPa}\right)$

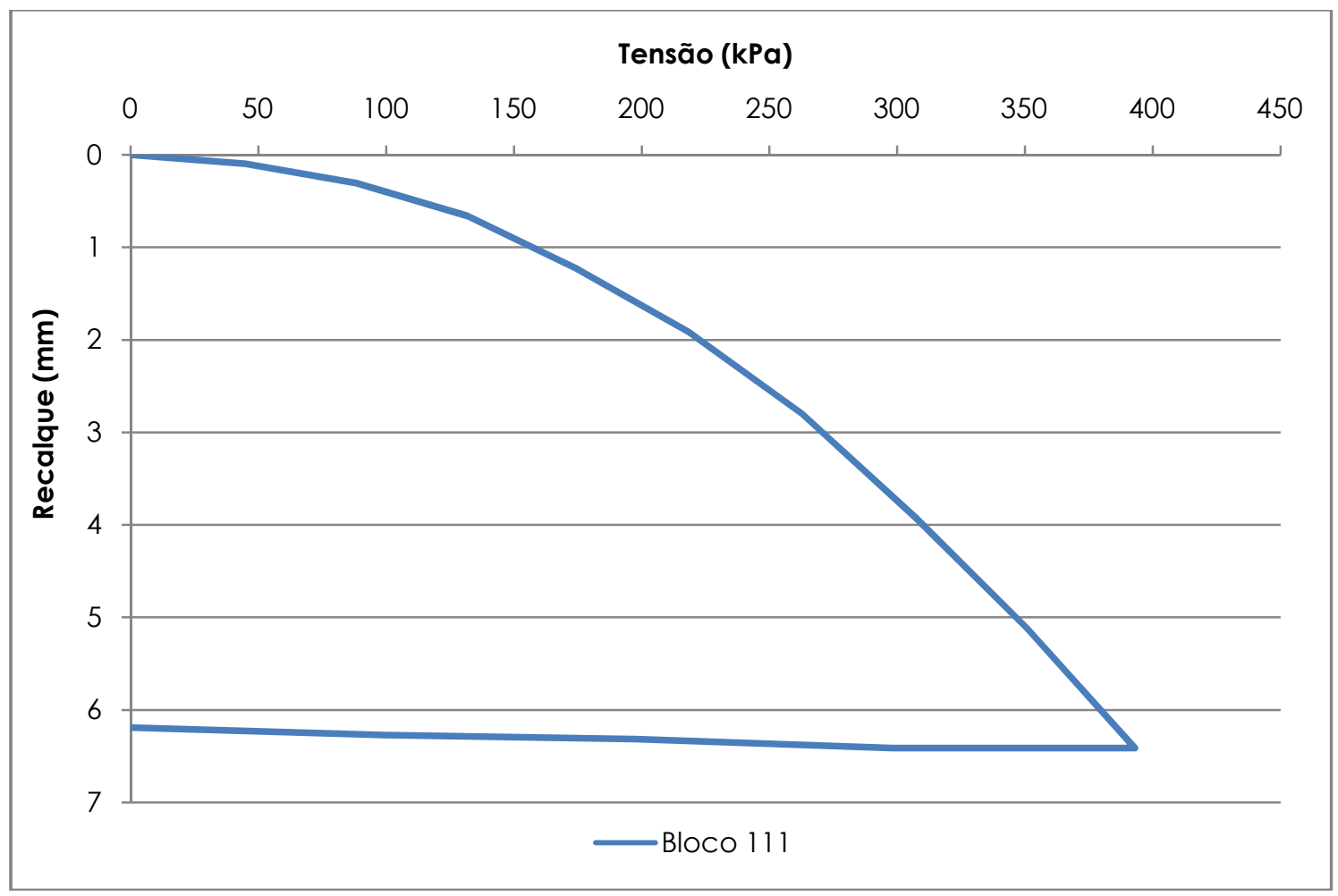

Figura4. 3 - Curva tensão $x$ recalque do ensaios $S M L(\psi m=35 \mathrm{kPa})$ 


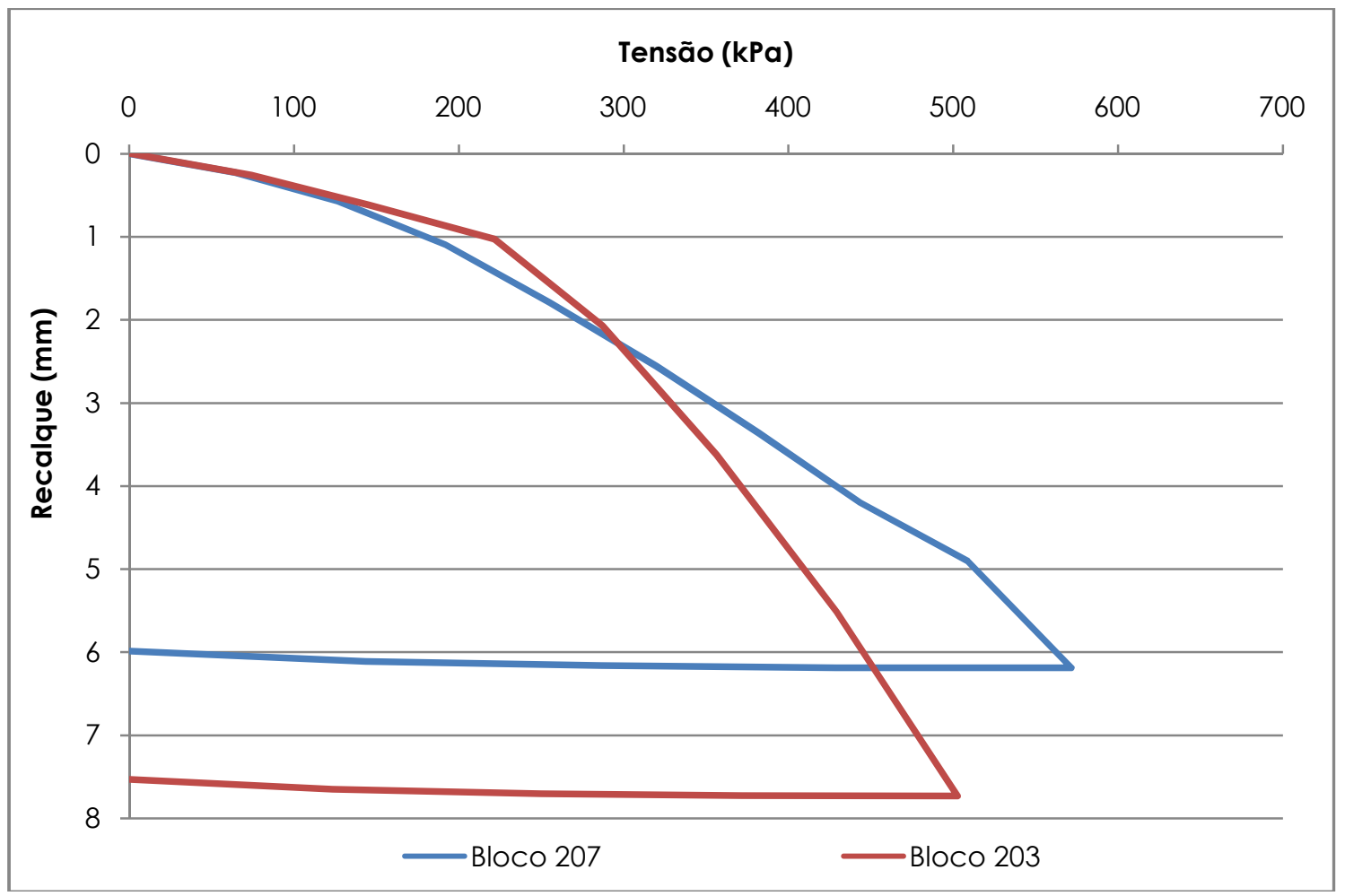

Figura4. 4- Curvas tensão $\times$ recalque dos ensaios SML $(\psi \mathrm{m}=45 \mathrm{kPa})$

\subsection{Prova de Carga Rápida - QML}

Foram realizadas oito provas de carga rápida, com duração de 5 min em cada estágio, nos dois primeiros ensaios (blocos 105 e 112), e 15 min nos demais. Programou-se a aplicação do carregamento de modo a obter cerca de 20 estágios. Nas Figura 4.5 a 4.8 são exibidas as curvas tensão x recalque relativas à série de provas realizadas pelo SML, agrupadas de acordo com a sucção matricial. 
Prova de carga rápida com recalque estabilizado

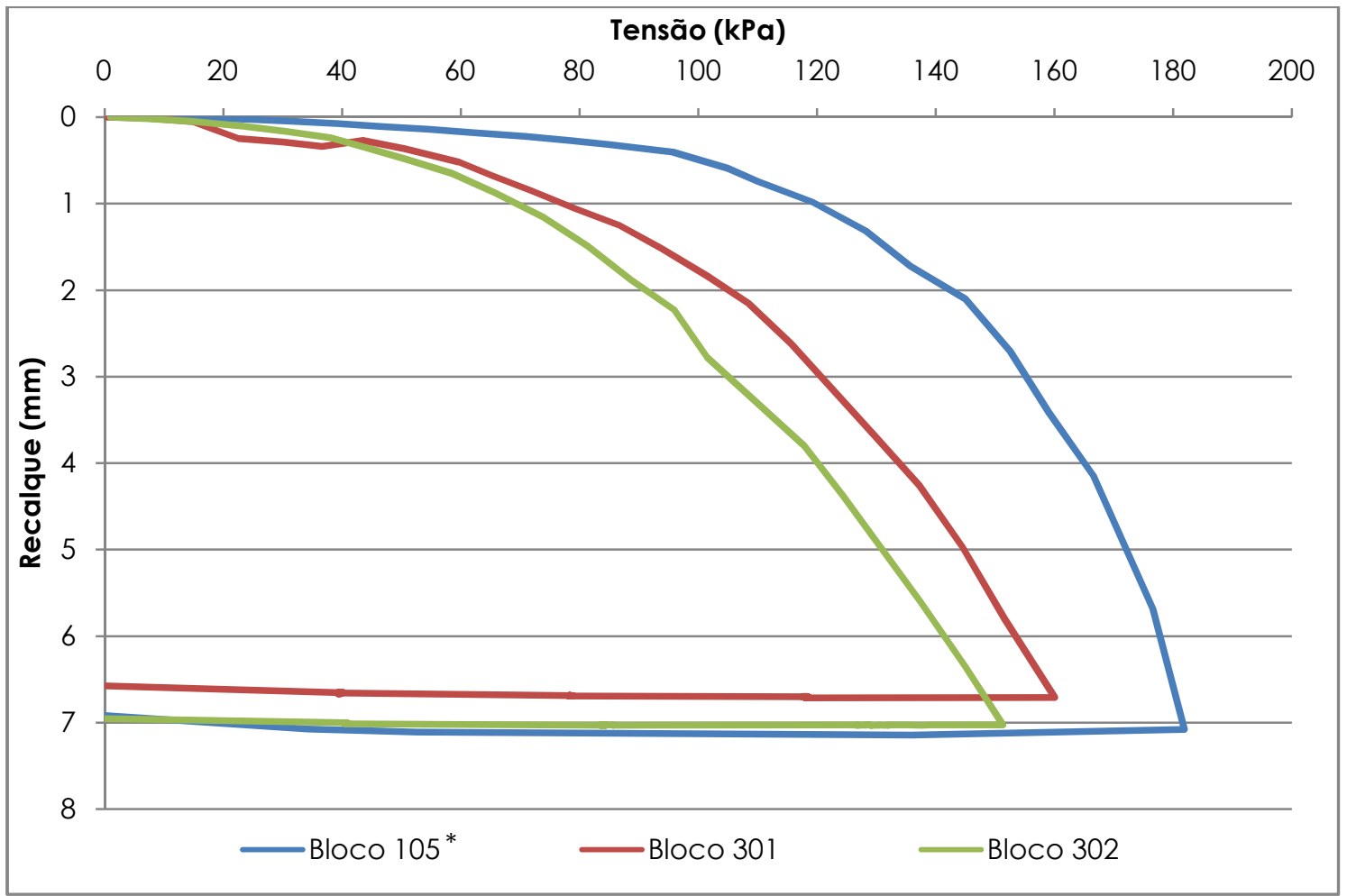

Figura4. 5- Curvas tensão $x$ recalque dos ensaios $Q M L(\psi m \cong 0)$

* duração de 5 min em cada estágio

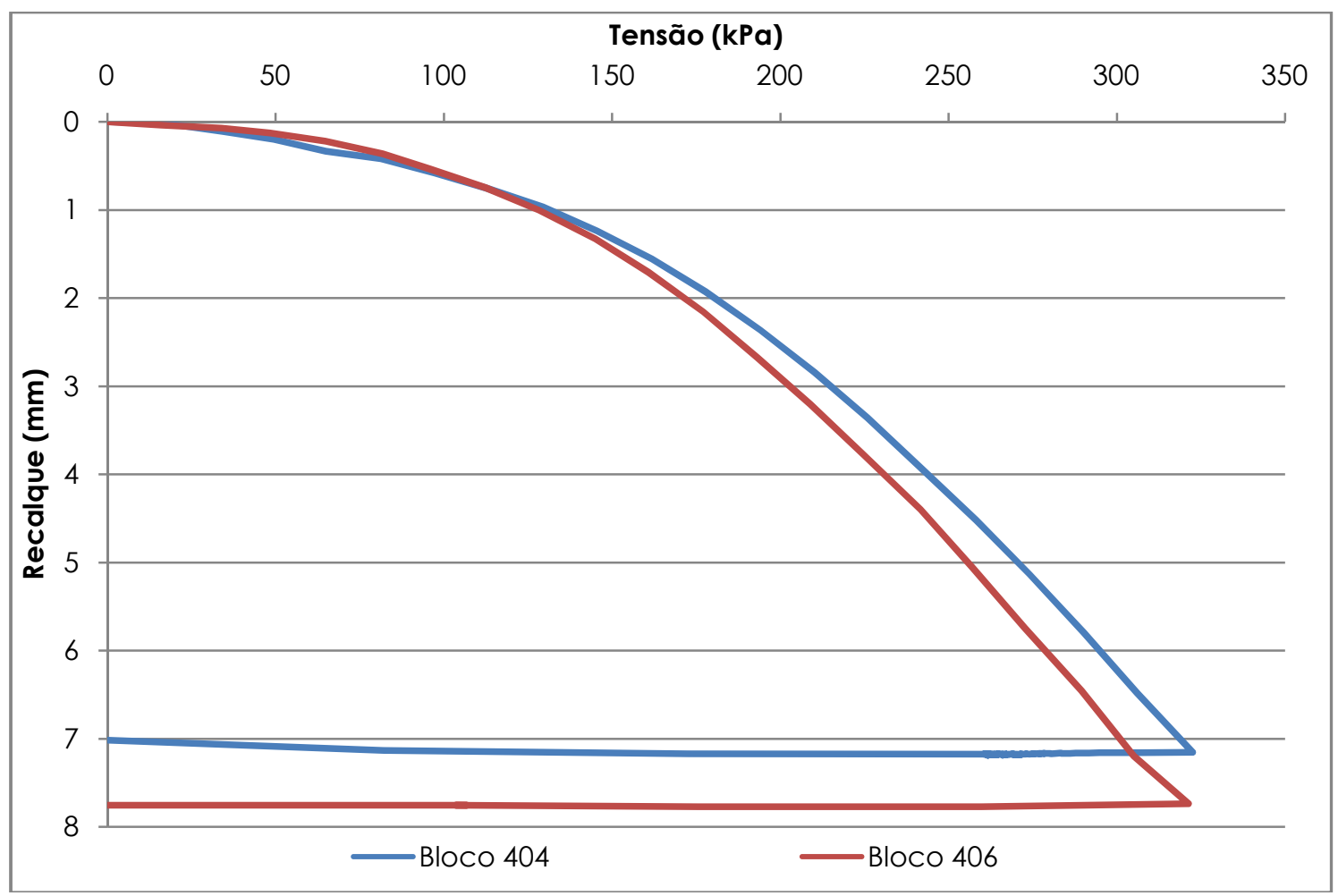

Figura4. 6- Curvas tensão $\times$ recalque dos ensaios SML $(\psi m=10 \mathrm{kPa})$ 


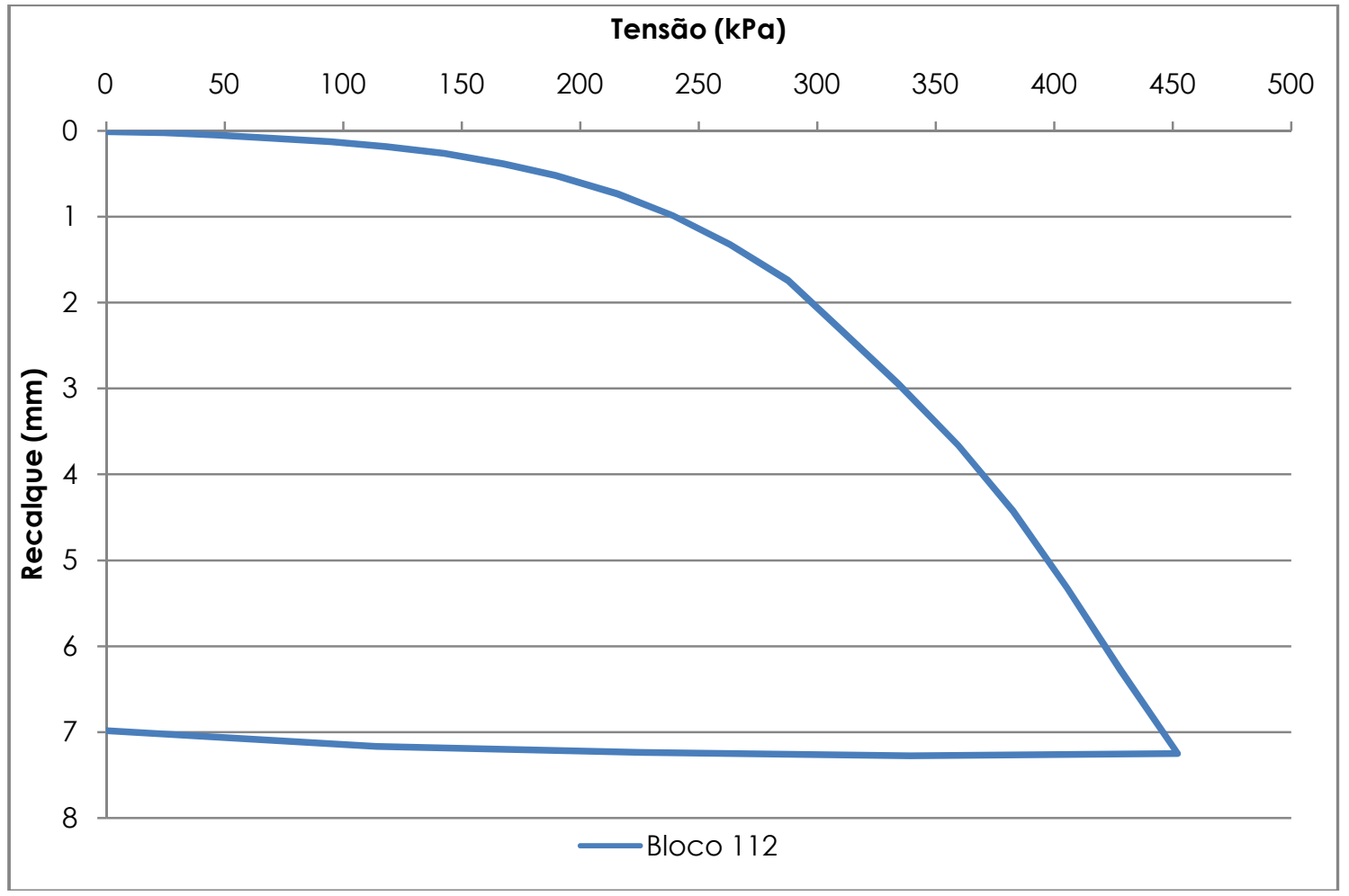

Figura4. 7 - Curva tensão $\times$ recalque dos ensaios SML $\left(\psi_{m}=35 \mathrm{kPa}\right)$

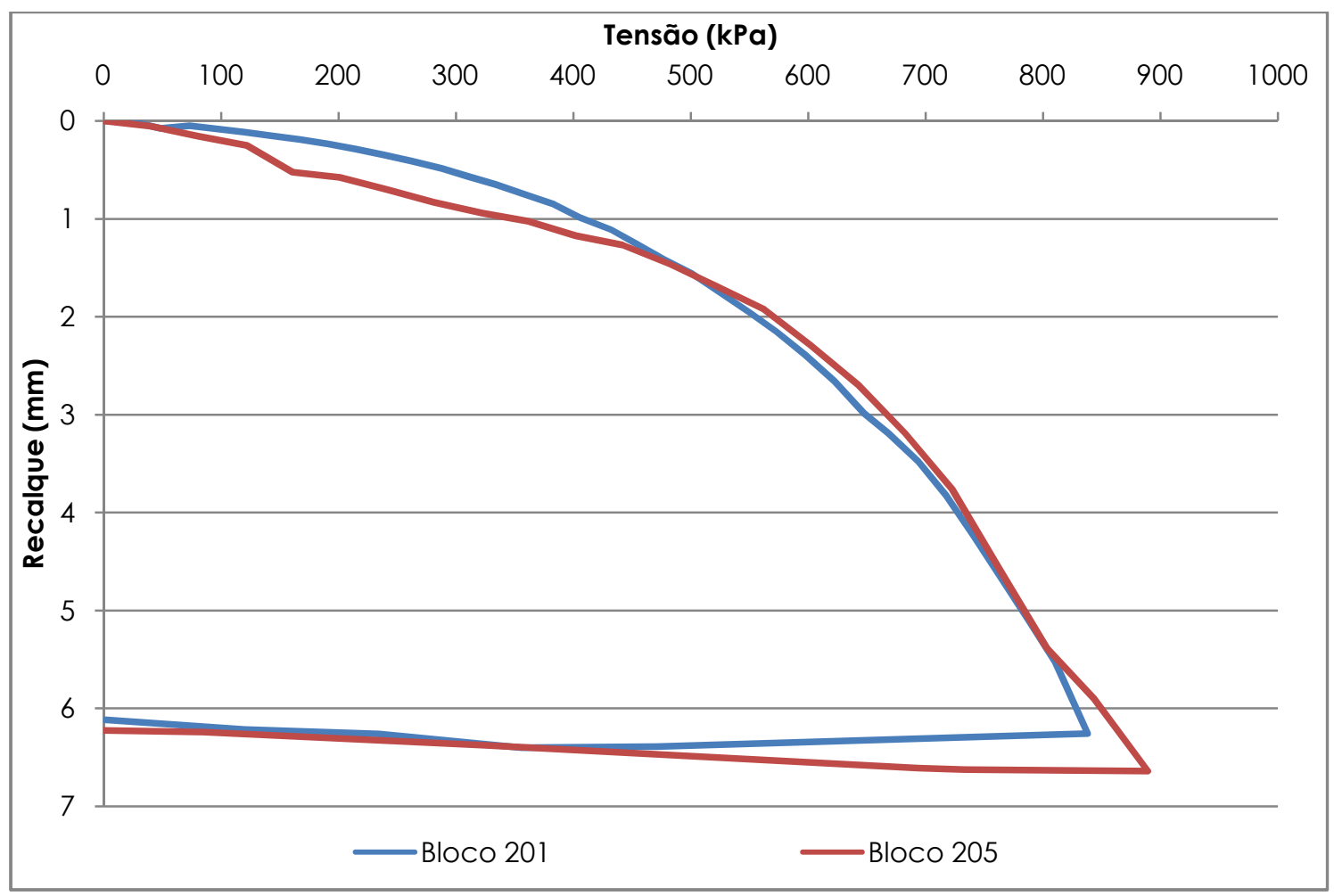

Figura4. 8- Curvas tensão $\times$ recalque dos ensaios SML $(\psi \mathrm{m}=45 \mathrm{kPa})$ 
Prova de carga rápida com recalque estabilizado

\subsection{Método do Equilíbrio - NML}

Para realização do ensaio através do método do equilíbrio seguiram-se as recomendações propostas por MOHAN (1967), mas introduzindo a fixação da duração dos estágios, tal como no QML. Assim, o carregamento deveria ser conduzido em vinte estágios de carga com duração de 15 min. Em cada estágio, a tensão, era mantida constante nos primeiros 5 min, através do controle de força da Prensa MTS-815 e, logo em seguida, passava-se para o controle de deslocamento de forma que a carga não fosse mantida nos 10 min seguintes.

Em todos os oito ensaios realizados, observou-se que o recalque estabilizava rapidamente, enquanto que a carga continuava a diminuir seu valor com tendência à estabilização. Pelo método proposto por MOHAN, a tensão e a carga deveriam estabilizar por completo, independente do tempo, mas neste trabalho, optou-se por fixar um critério de tempo para todos os estágios. Como se notou que 10 min eram suficientes para determinar a tendência de queda da tensão, fixou-se a duração do estágio em 15 min. Isso mostrou é grande vantagem, pois antes de começar o ensaio, é possível prever o seu tempo de execução do ensaio. Com 20 estágios de carregamento mais quatro estágios de descarregamento, o tempo total fica reduzido a seis horas. Nas Figuras 4.9 a 4.12 são exibidas as curvas tensão $x$ recalque relativas à série de provas de carga, realizadas pelo NML, agrupadas de acordo com a sucção matricial. 


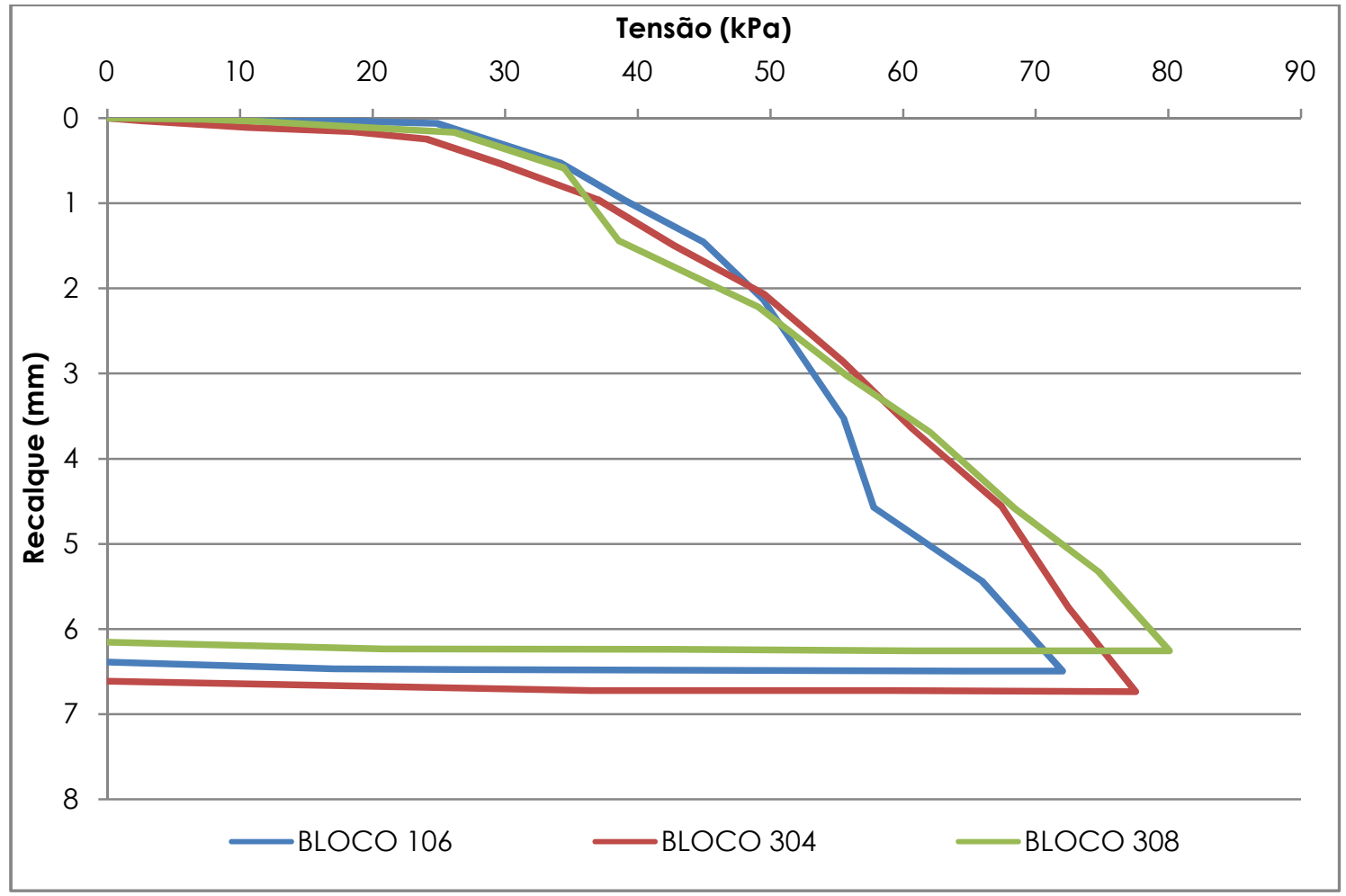

Figura4. 9 - Curvas tensão $\times$ recalque dos ensaios NML $(\psi m \cong 0)$

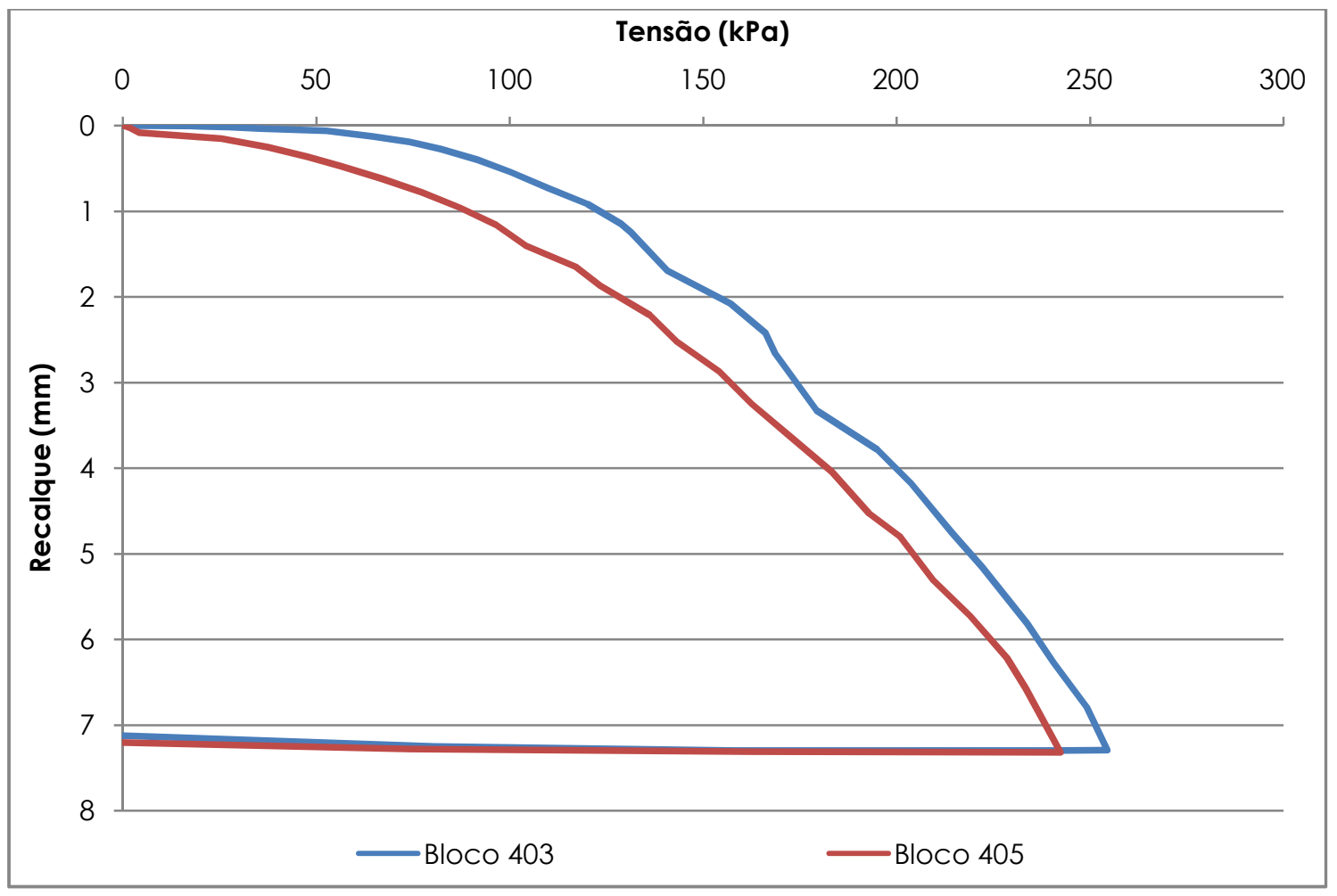

Figura4. 10- Curvas tensão $\times$ recalque dos ensaios NML $(\psi \mathrm{m} \cong 10 \mathrm{kPa})$ 
Prova de carga rápida com recalque estabilizado

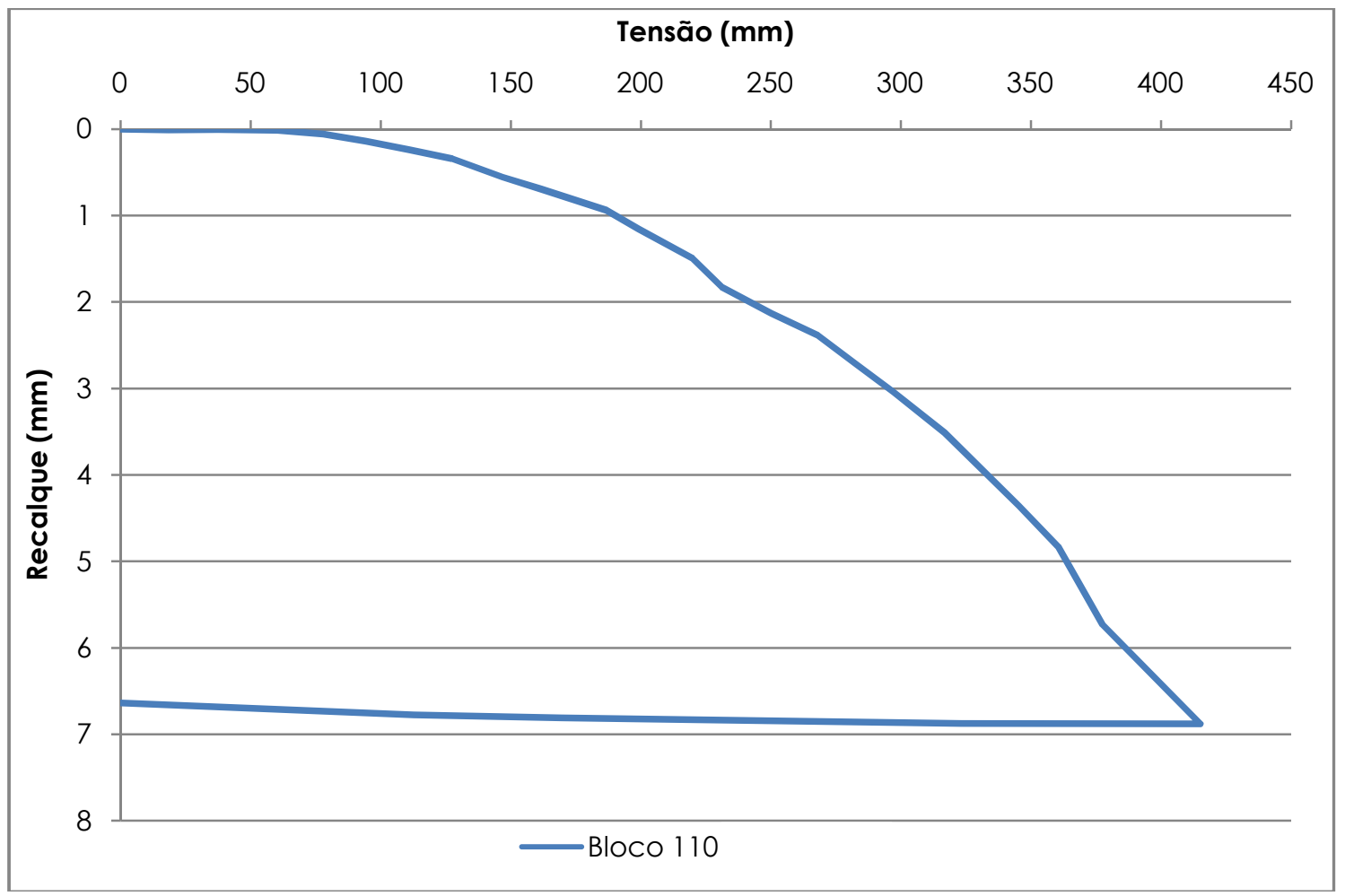

Figura4. 11- Curva tensão $\times$ recalque dos ensaios NML $(\psi \mathrm{m}=35 \mathrm{kPa})$

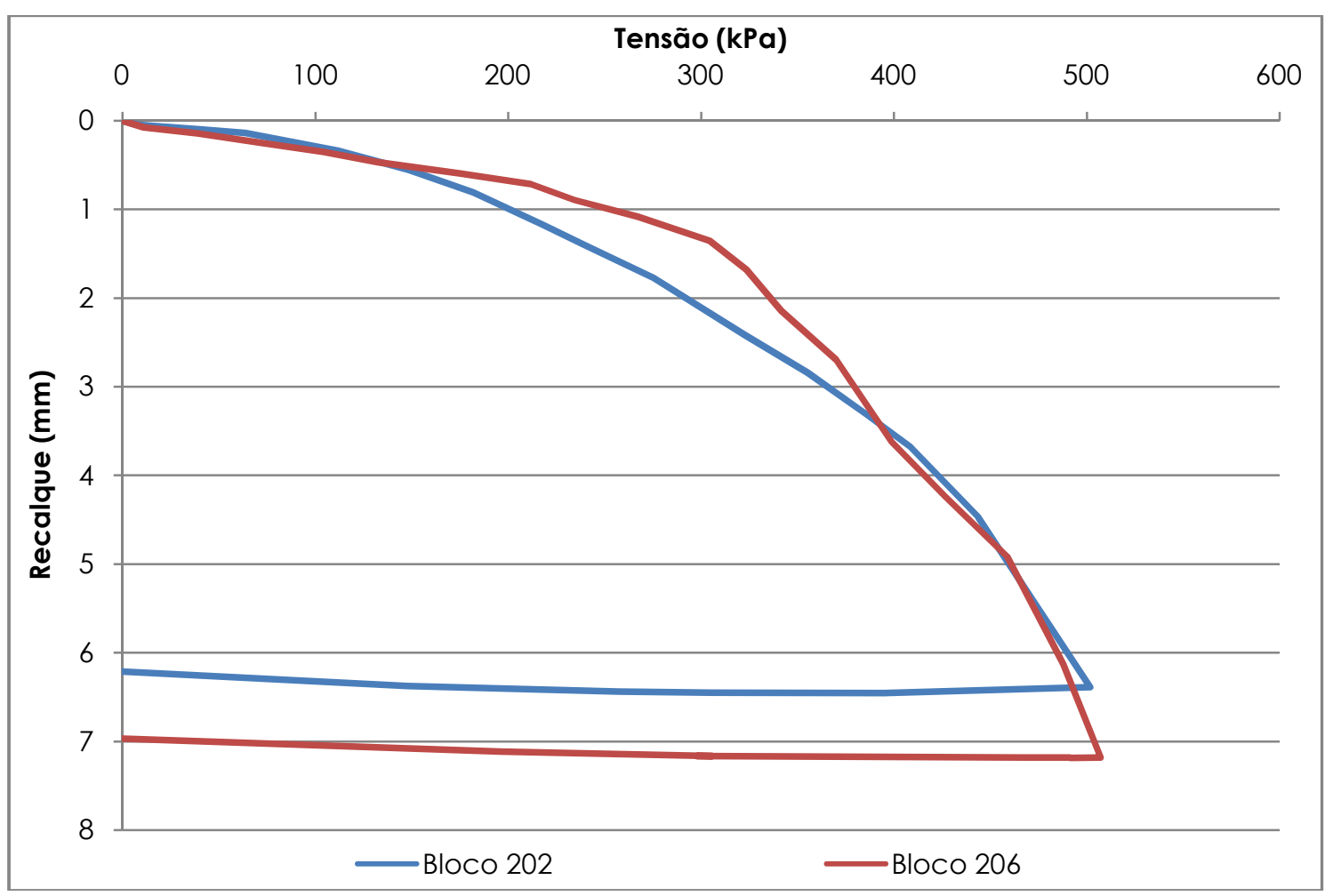

Figura4. 12- Curvas tensão $\times$ recalque dos ensaios $\mathrm{NML}\left(\psi_{\mathrm{m}}=45 \mathrm{kPa}\right)$ 


\section{ANÁLISE DOS RESULTADOS}

\subsection{Curva tensão x recalque para o Método do Equilíbrio - NML}

Durante a execução da prova de carga pelo método do equilíbrio, foram realizadas leituras do recalque e da carga, em tempos pré-determinados. Conforme exemplificado pela Figura 5.1, para um determinado estágio de tensão, o recalque estabilizava rapidamente, ou seja, um deslocamento inicial ocorria e permanecia constante ao longo do tempo. Entretanto, a carga continuava a diminuir o seu valor, com tendência à estabilização, conforme a Figura 5.2.

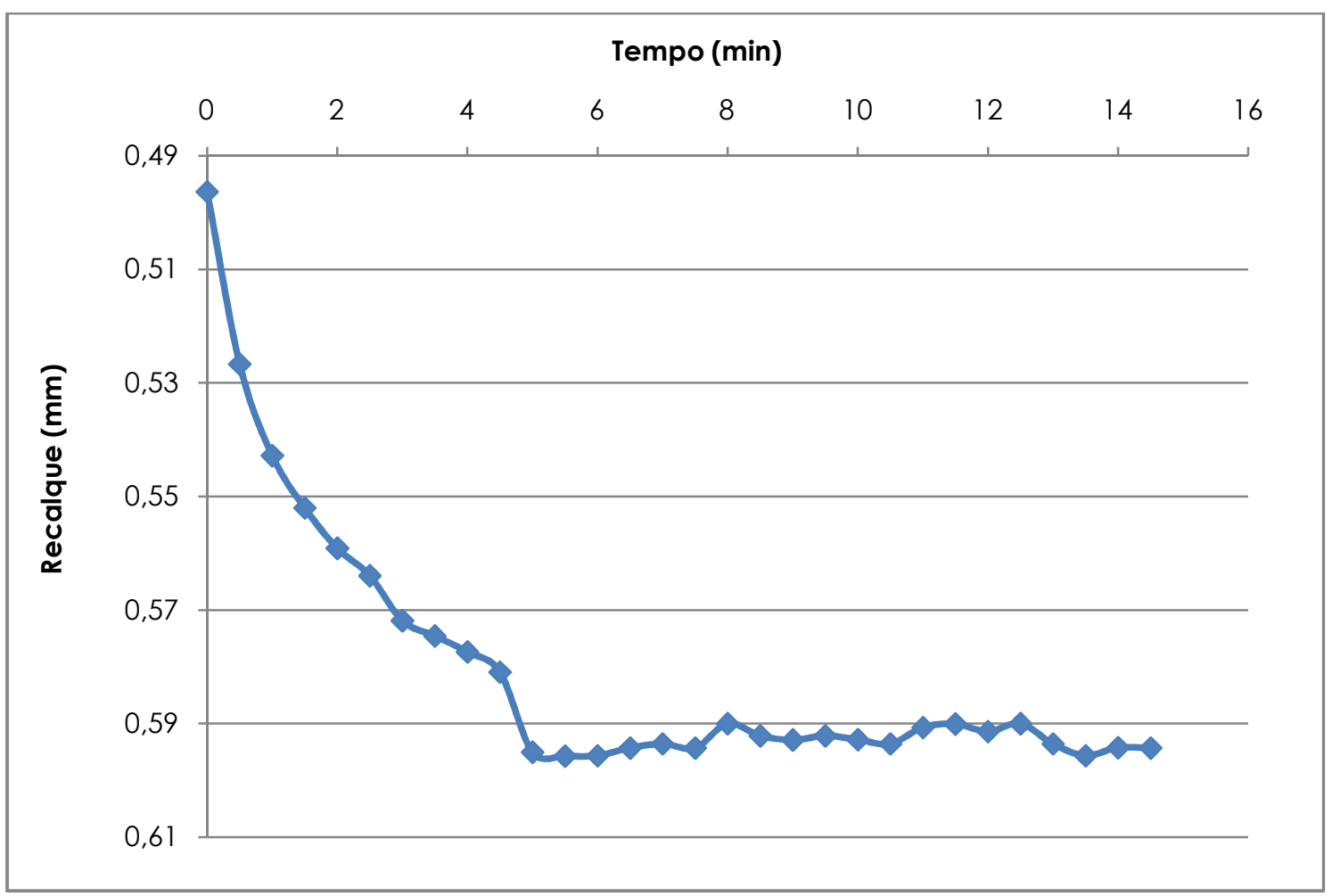

Figura 5. 1-Variação do recalque com o tempo no estágio com tensão inicial de $240 \mathrm{kPa}(\psi \mathrm{m}=45 \mathrm{kPa})$ 
Prova de carga rápida com recalque estabilizado

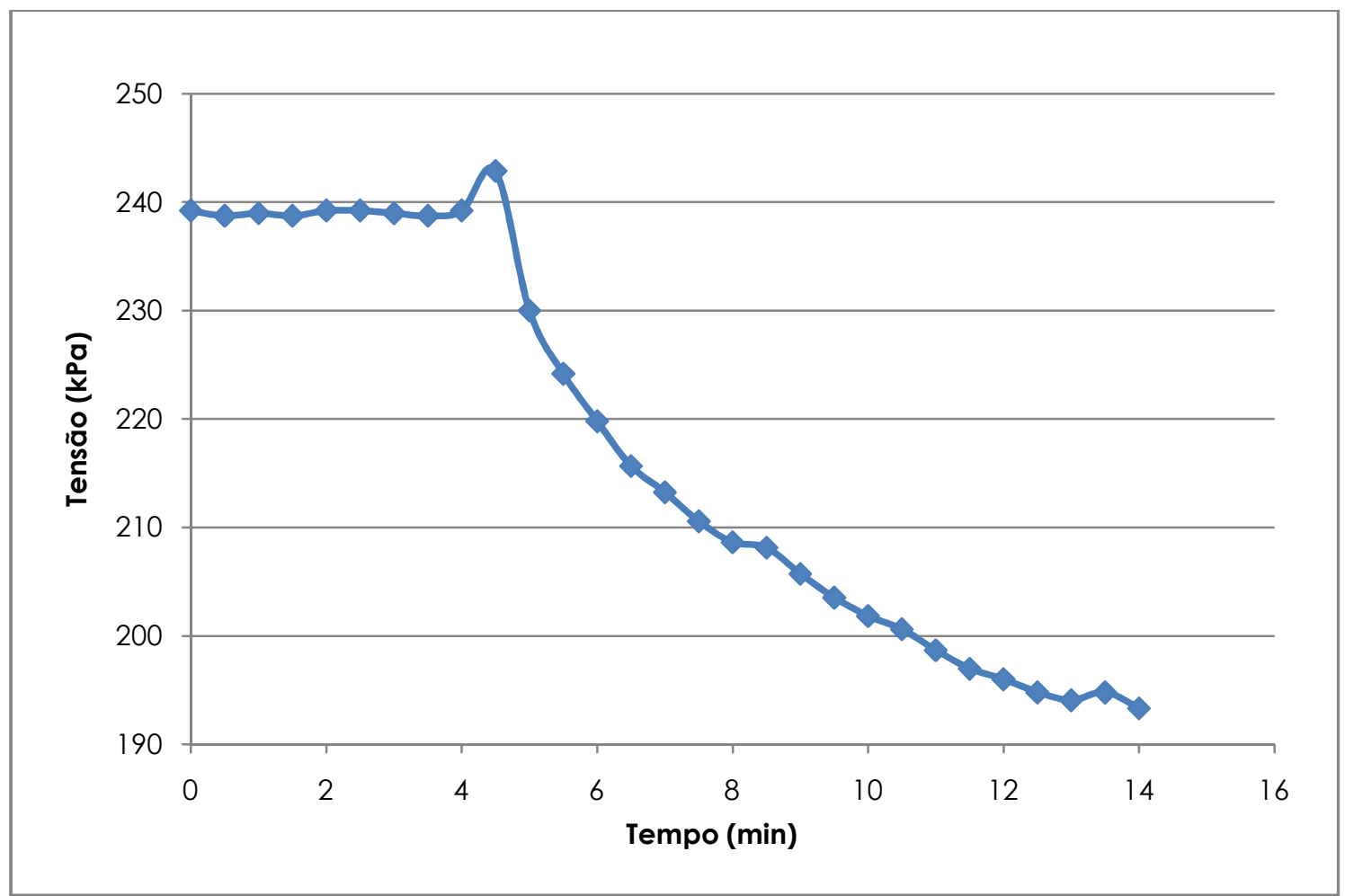

Figura 5. 2- Variação da tensão com o tempo no estágio com tensão inicial de $240 \mathrm{kPa}\left(\psi_{\mathrm{m}}=45 \mathrm{kPa}\right)$

A curva da variação da tensão no tempo, em cada estágio, na fase de carga não mantida, tinha forma exponencial com tendência a uma assíntota horizontal. Por este motivo, para determinar o valor estabilizado da tensão utilizou-se o programa Table Curve 2D para ajustar uma curva, conforme Figura 5.3, por exemplo. Esse programa encontra uma série de equações possíveis de serem aplicadas à curva, exigindo um estudo gráfico no Excel para determinar qual equação estava mais próxima dos pontos obtidos experimentalmente, conforme exemplificado na Figura 5.4. Para confirmar o melhor ajuste de curva era realizado um novo estudo de ajuste de curva, porém desta vez excluindo os dados obtidos nos últimos 5 minutos. Era eleita a equação apropriada aquela que obtive-se o resultado mais próximo nos dois estudos realizados. Este procedimento foi aplicado a todos os estágios de carregamento, tanto para o ensaio inundado como para o não inundado.

Para o recalque não foi necessário nenhum ajuste, pois o valor estabilizado era encontrado no próprio ensaio. 


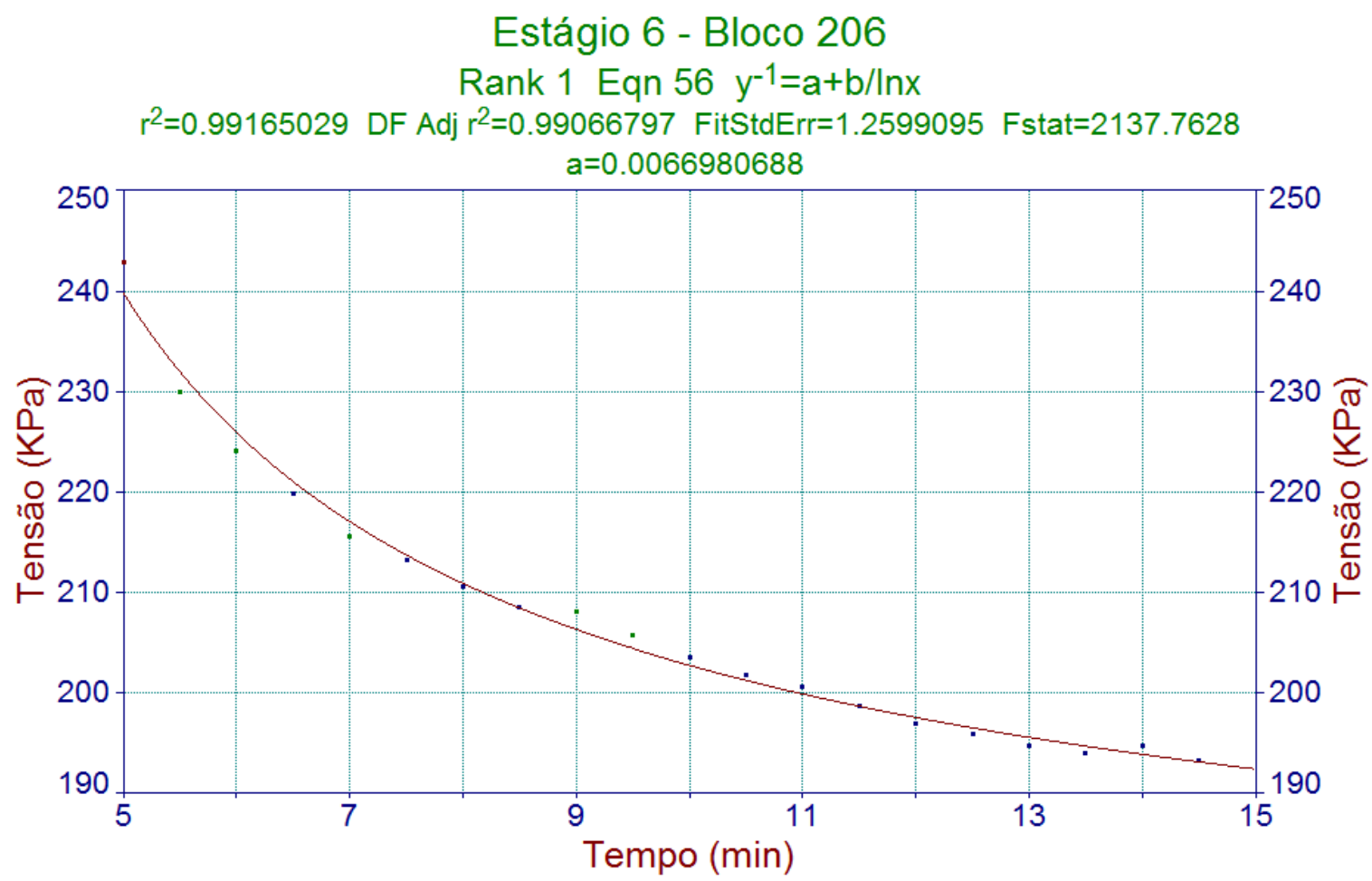

Figura 5. 3- Curva de ajuste utilizada para determinar o valor da tensão estabilizada (Programa Table Curve)

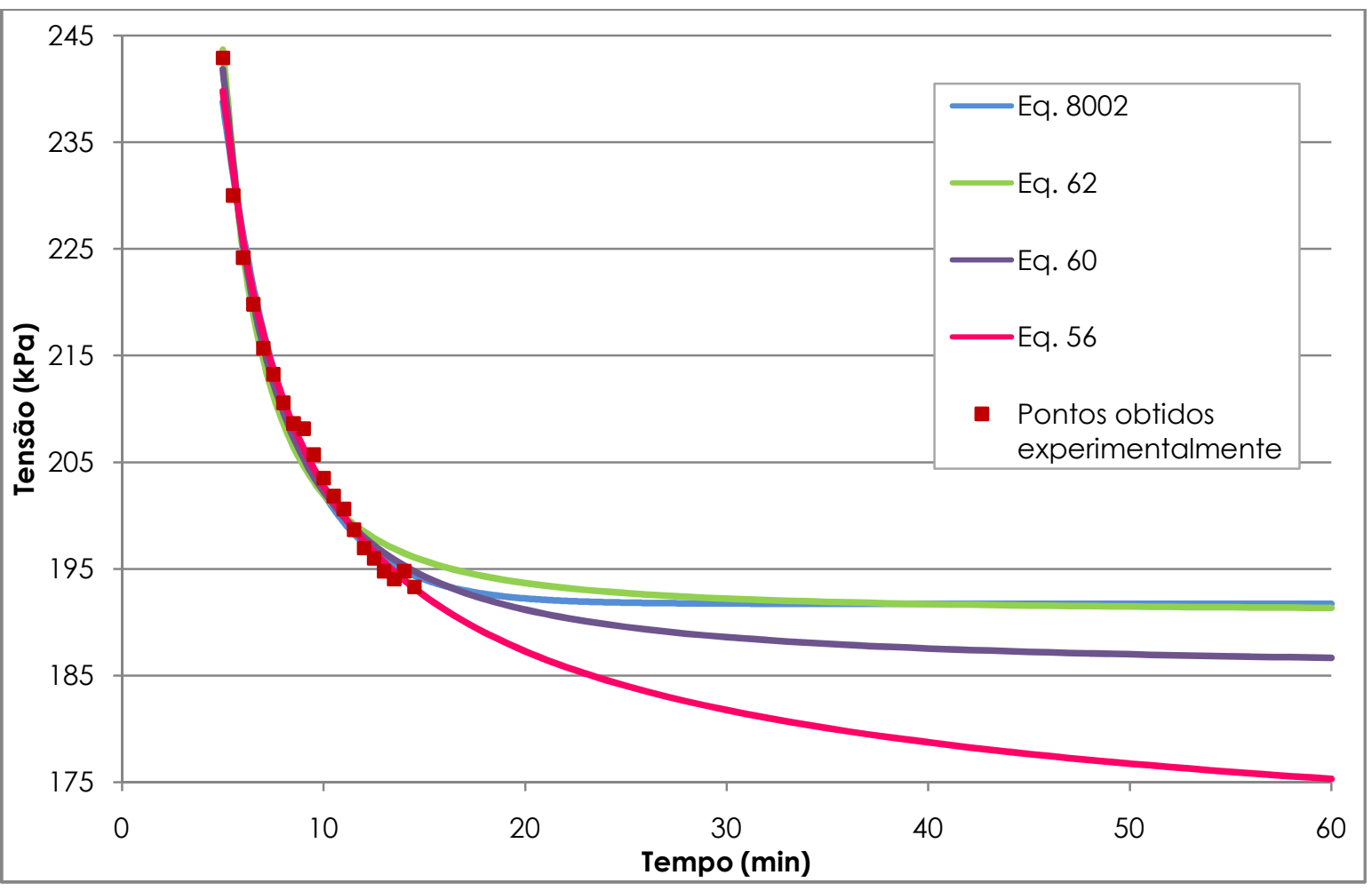

Figura 5. 4- Curvas de ajuste utilizadas para determinar o valor da tensão estabilizada 
Prova de carga rápida com recalque estabilizado

Nas Figura 5.5 a Figuras 5.12 estão apresentadas as curvas tensão x recalque obtidas nas provas de carga pelo método do equilíbrio (NML), para o ensaio inundado e não inundado $(15,35$ e $45 \mathrm{kPa})$.

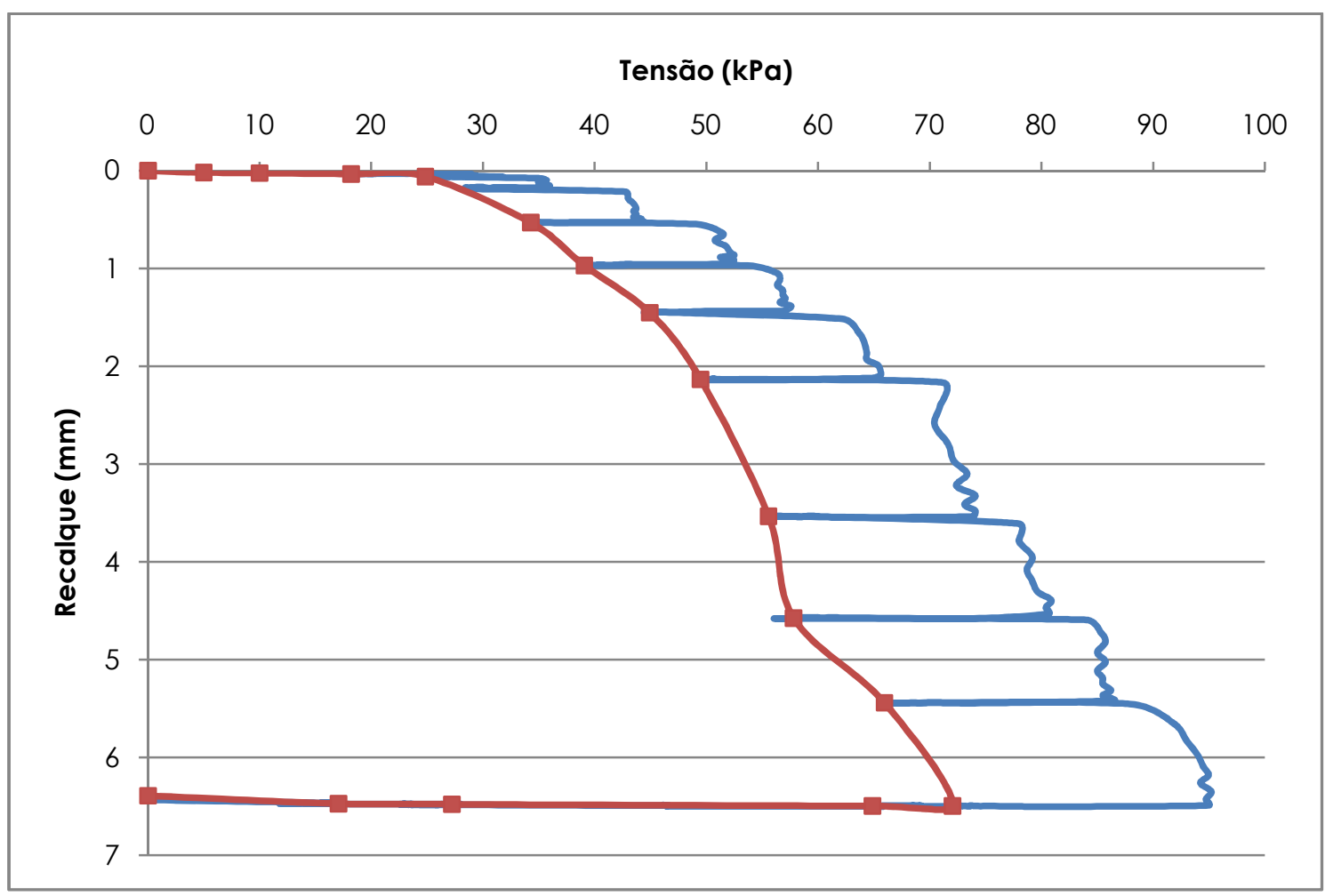

Figura 5. 5- Curva tensão x recalque obtida pelo método do equilíbrio (Bloco $106-\psi \mathrm{m} \cong 0$ ) 


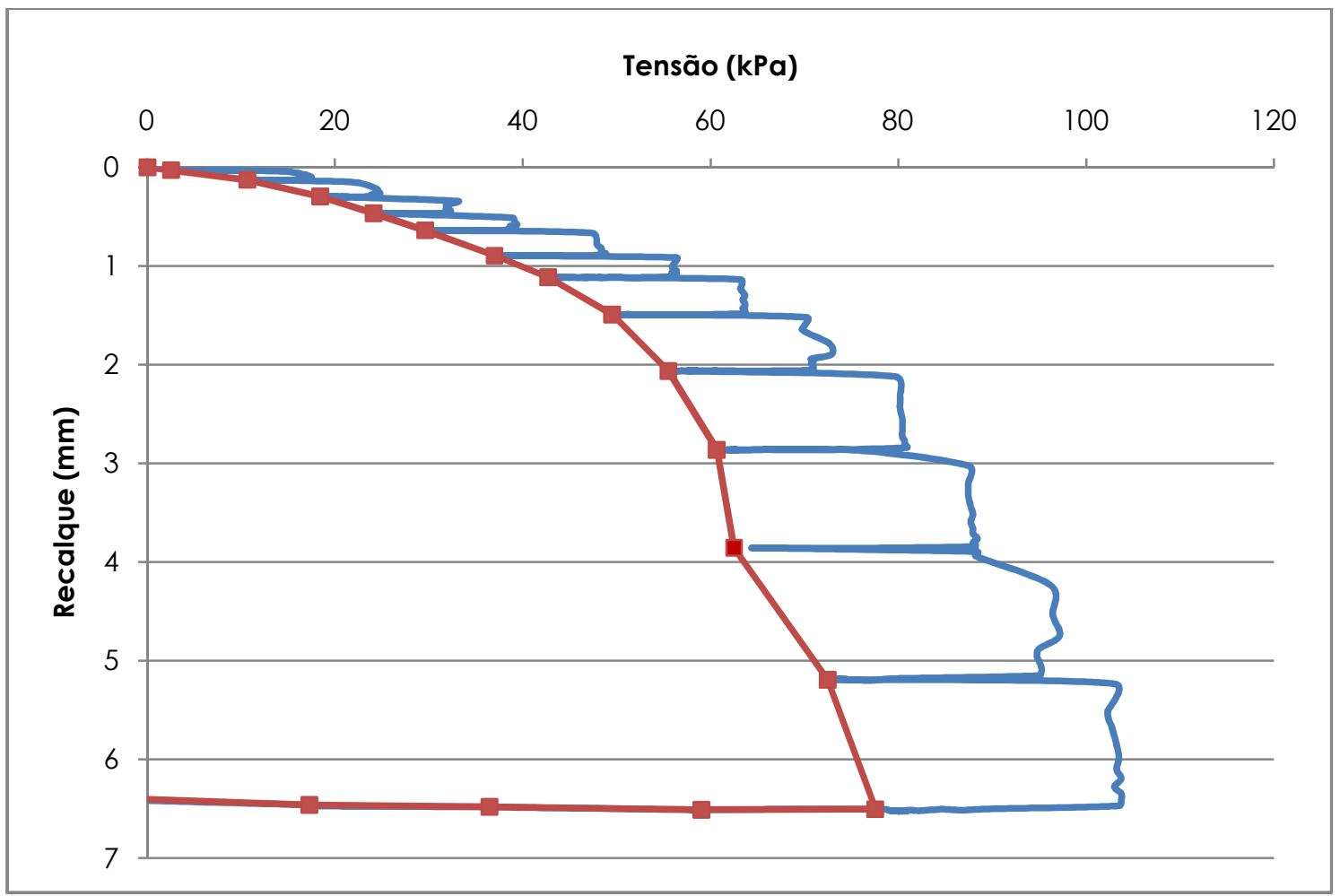

Figura 5. 6- Curva tensão $x$ recalque obtida pelo método do equilíbrio (Bloco $304-\psi_{m} \cong 0$ )

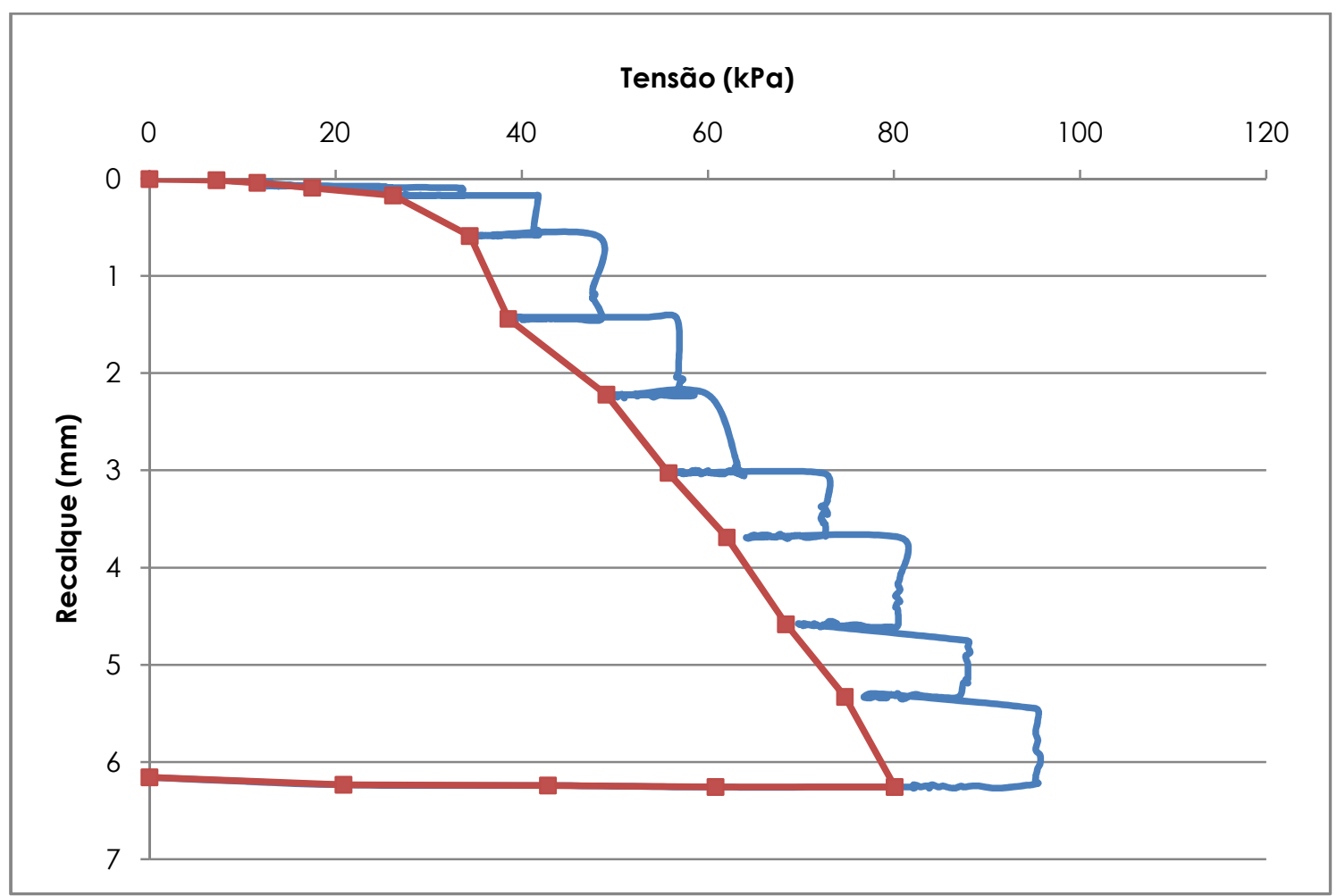

Figura 5. 7- Curva tensão $x$ recalque obtida pelo método do equilíbrio (Bloco $308-\psi_{\mathrm{m}} \cong 0$ ) 
Prova de carga rápida com recalque estabilizado

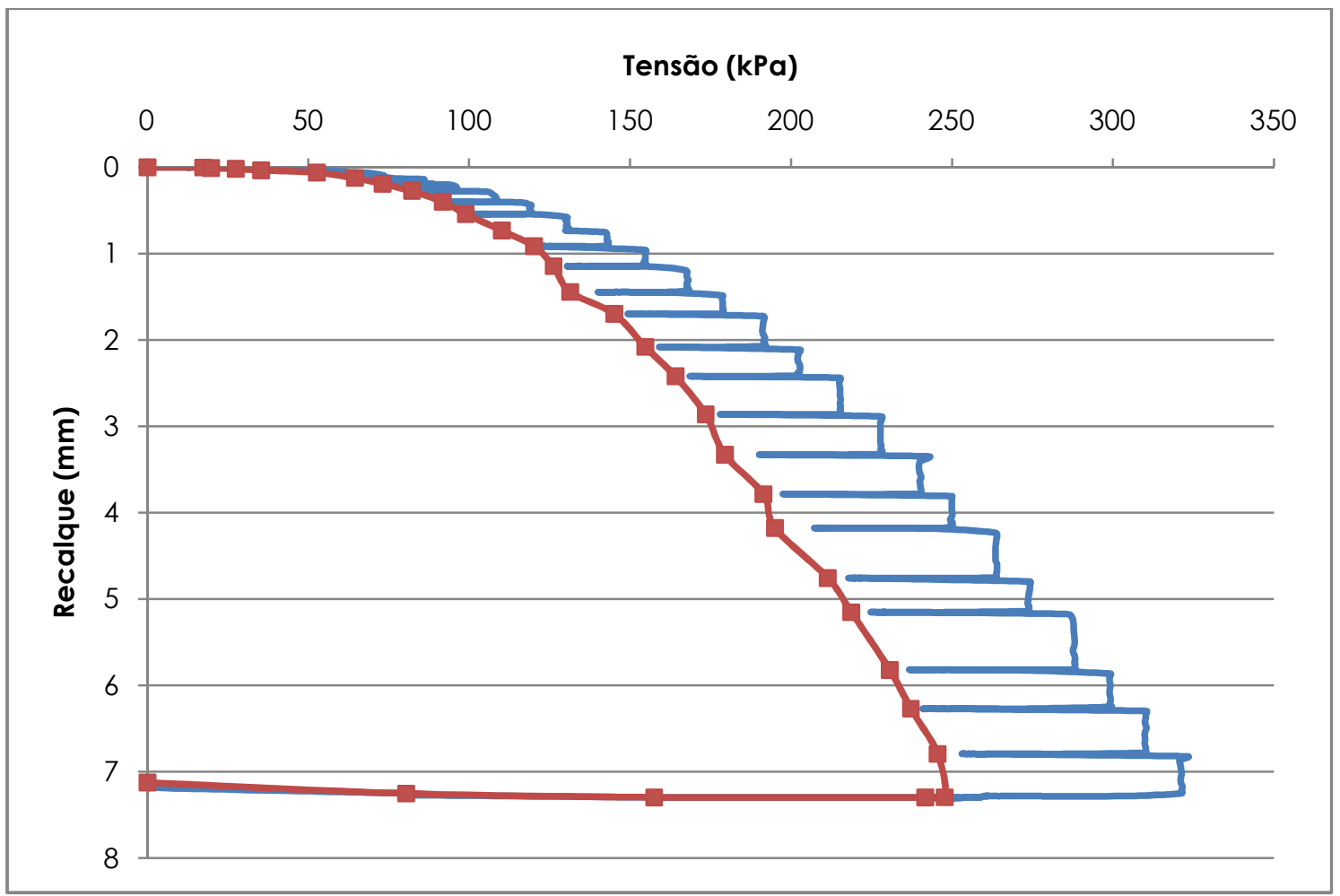

Figura 5. 8- Curva tensão $\times$ recalque obtida pelo método do equilíbrio (Bloco $403-\psi \mathrm{m}=10 \mathrm{kPa}$ )

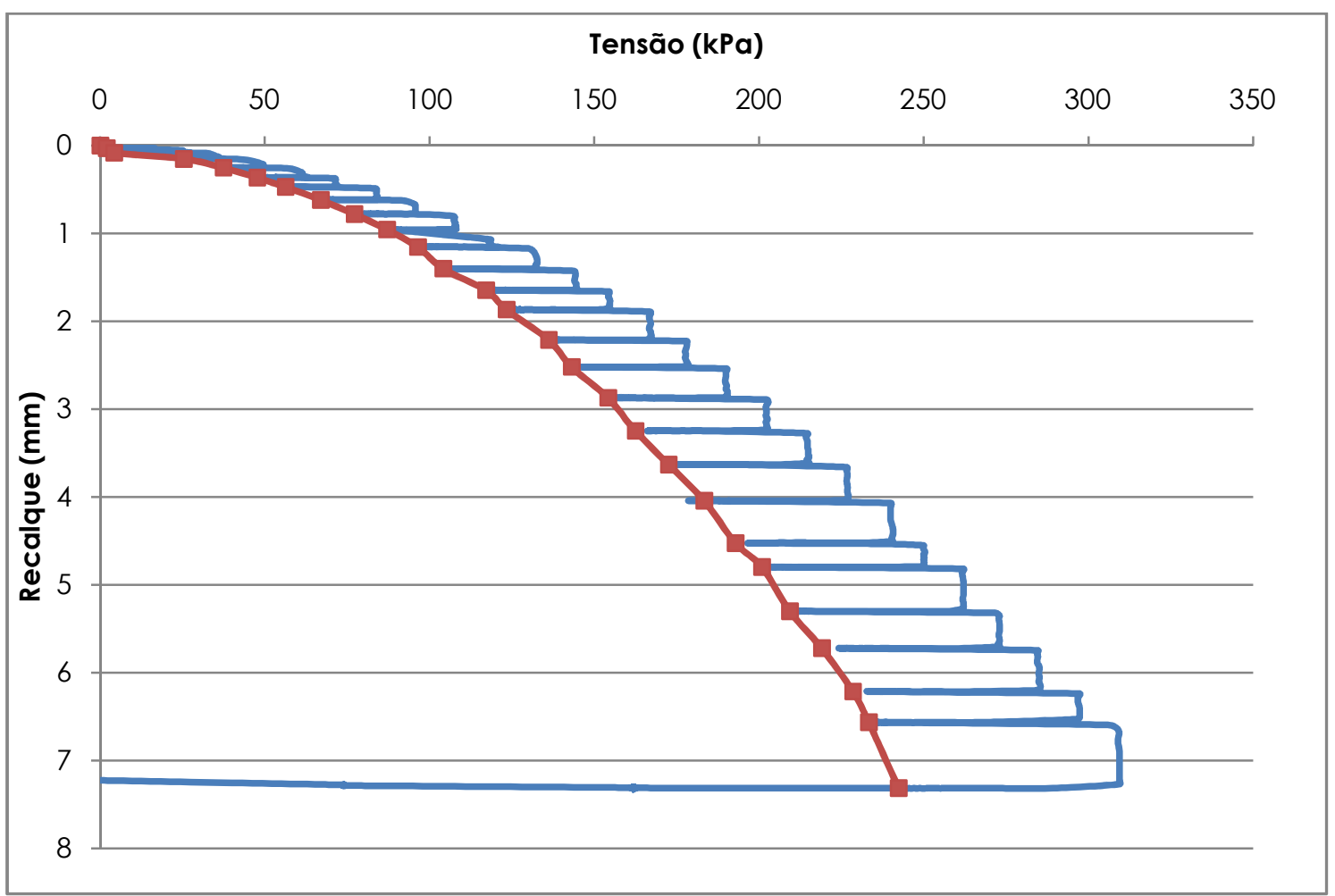

Figura 5. 9- Curva tensão $\times$ recalque obtida pelo método do equilíbrio (Bloco $405-\psi \mathrm{m}=10 \mathrm{kPa}$ ) 


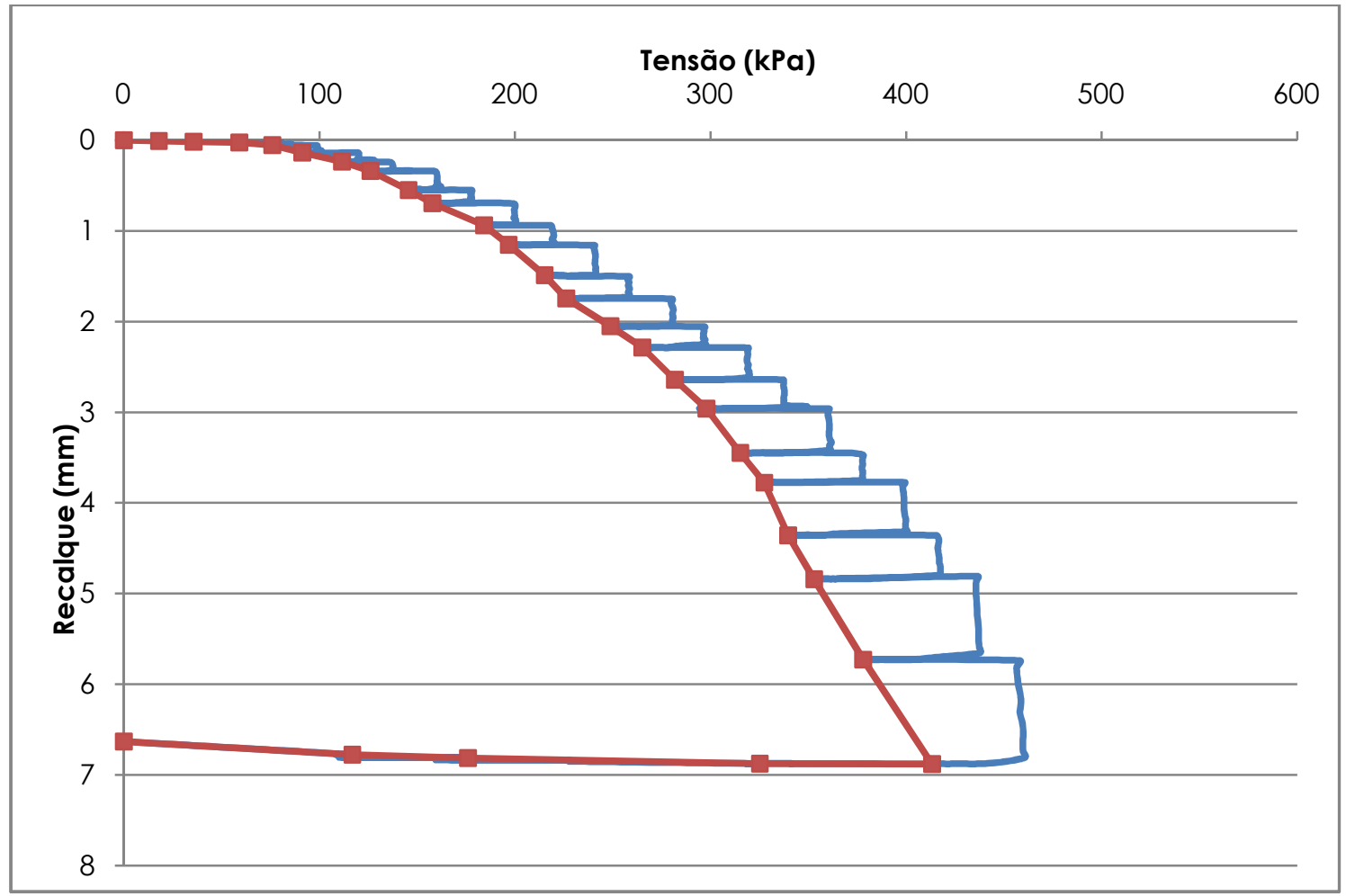

Figura 5. 10- Curva tensão $x$ recalque obtida pelo método do equilíbrio (Bloco $110-\psi \mathrm{m}=35 \mathrm{kPa}$ )

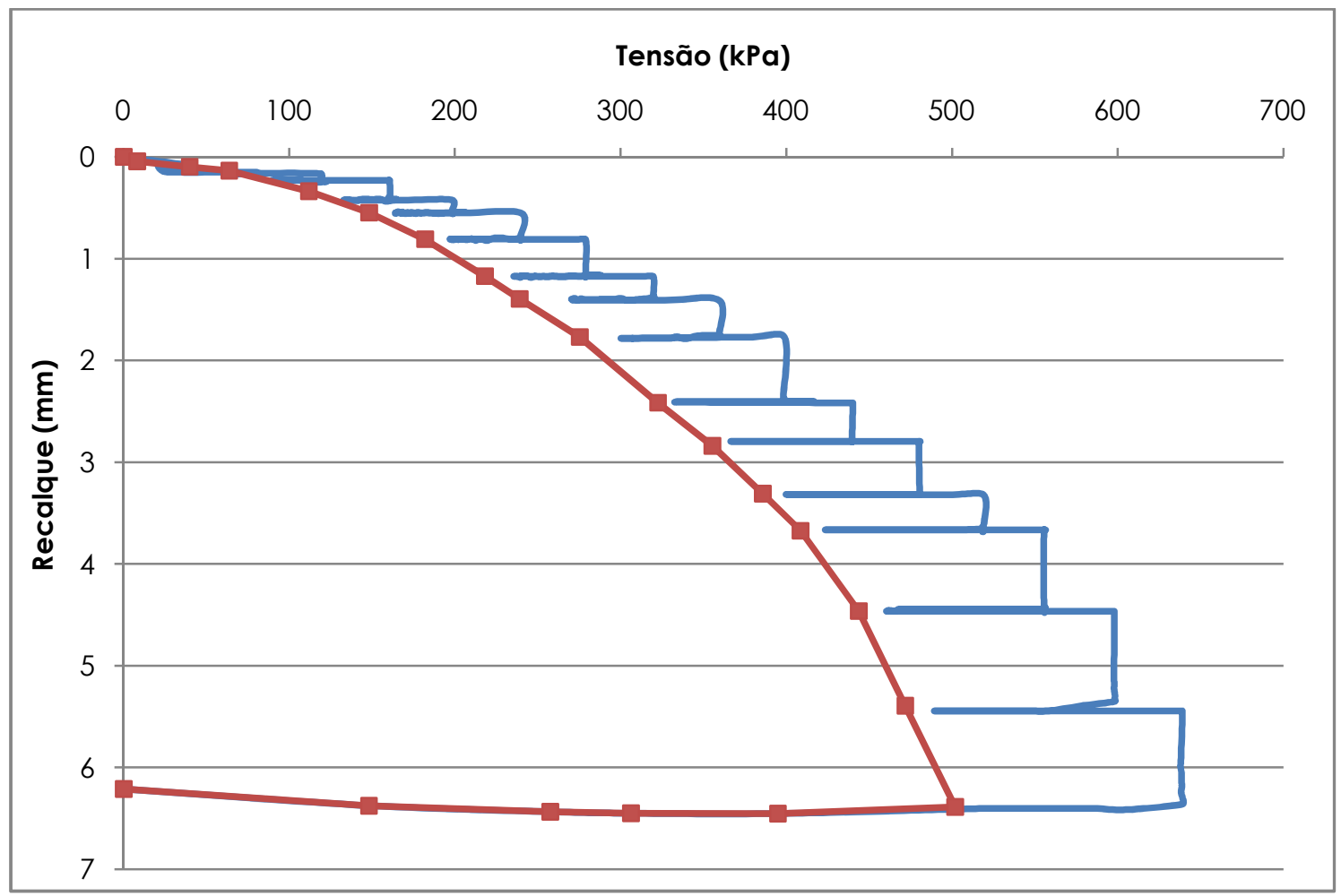

Figura 5. 11-Curva tensão $\times$ recalque obtida pelo método do equilíbrio (Bloco $202-\psi \mathrm{m}=45 \mathrm{kPa})$ 
Prova de carga rápida com recalque estabilizado

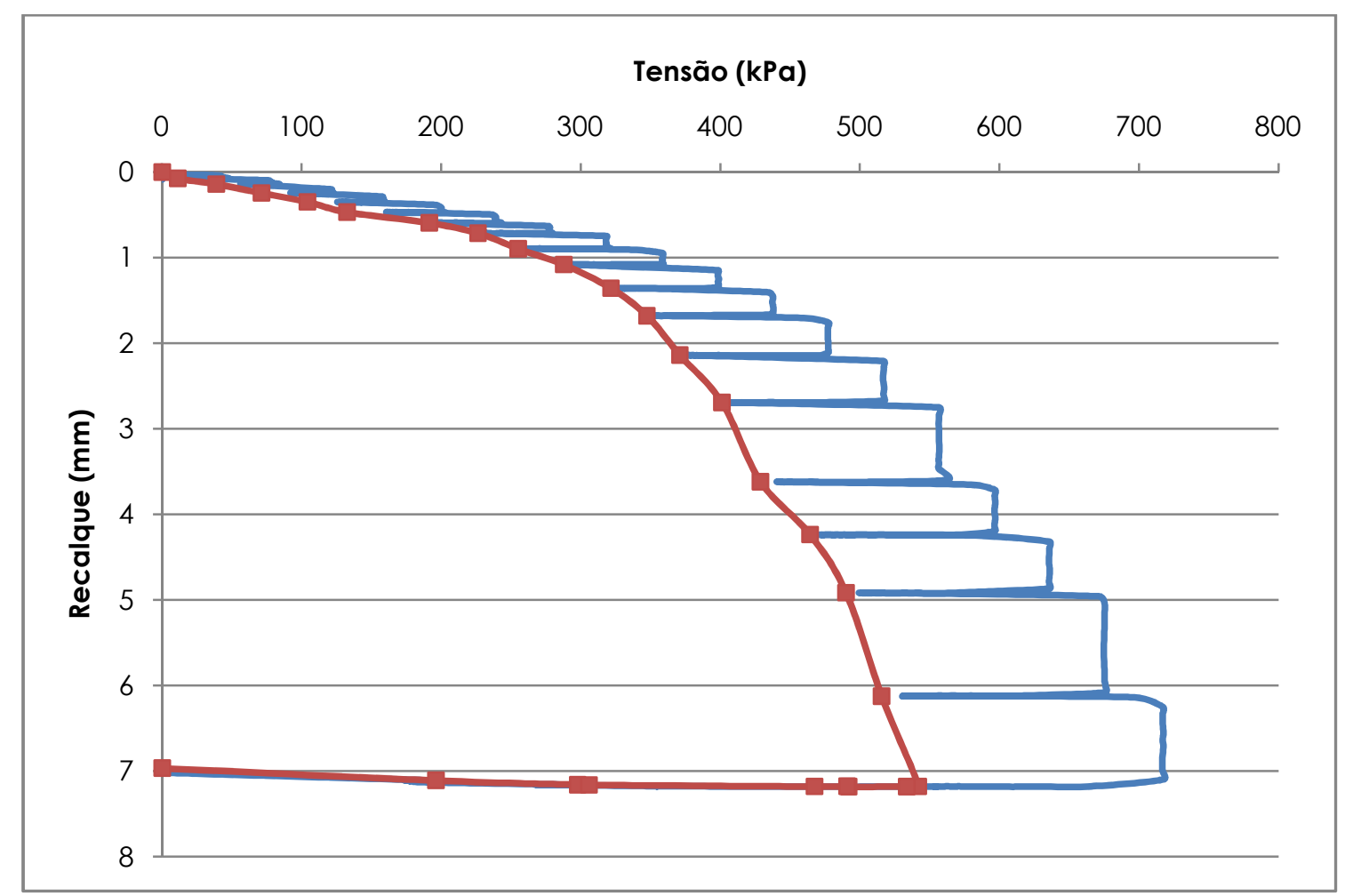

Figura 5. 12-Curva tensão $\times$ recalque obtida pelo método do equilíbrio (Bloco $206-\psi \mathrm{m}=45 \mathrm{kPa}$ )

Nas Figuras 5.13 e 5.16 estão apresentada as curvas tensão $x$ recalque obtidas nas provas de carga, agrupadas de acordo com a condição do solo, em termos de sucção matricial. 


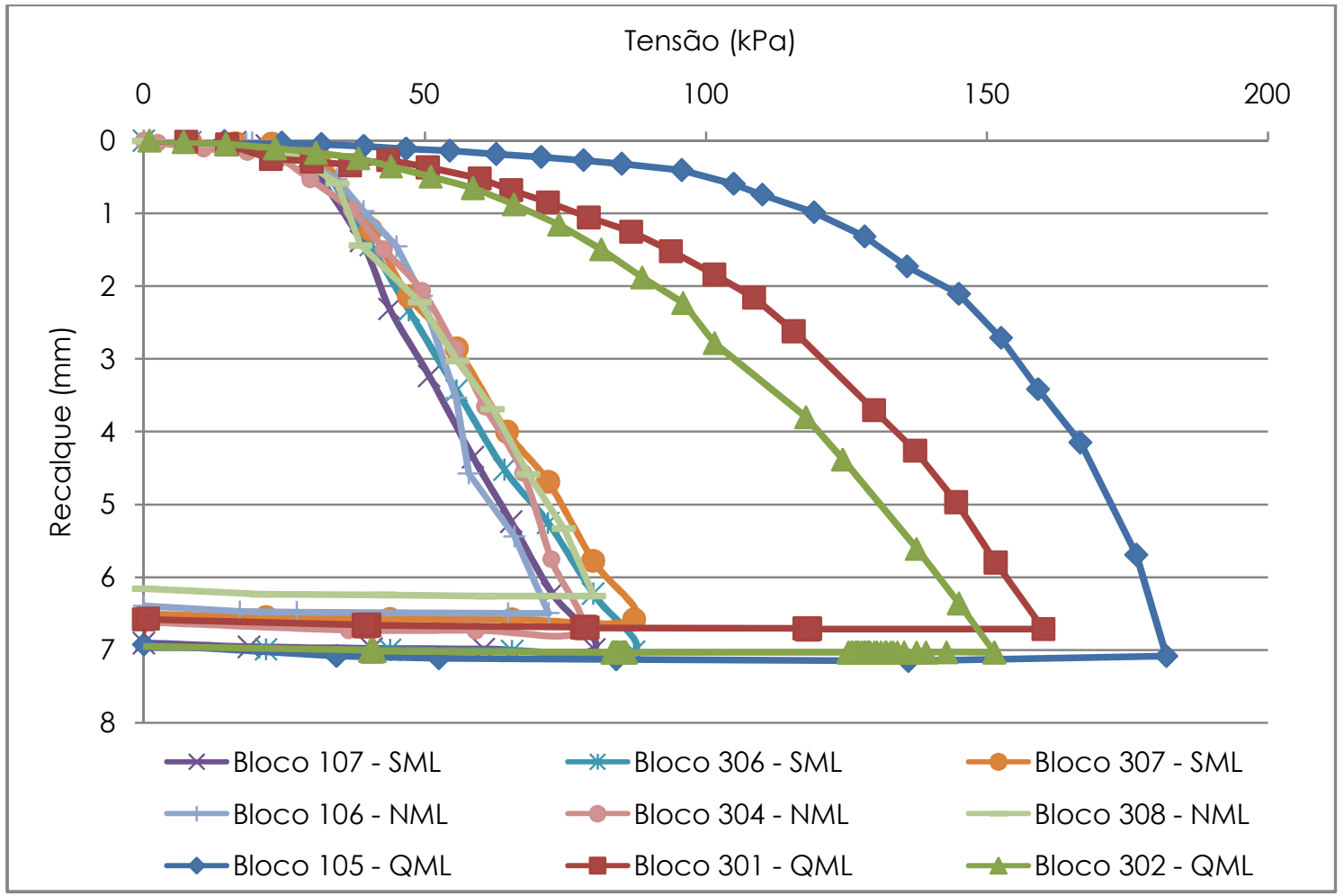

Figura 5. 13-Curvas tensão x recalque obtidas através nas de carga lenta, rápida e método do Equilíbrio $(\psi \mathrm{m} \cong 0)$.

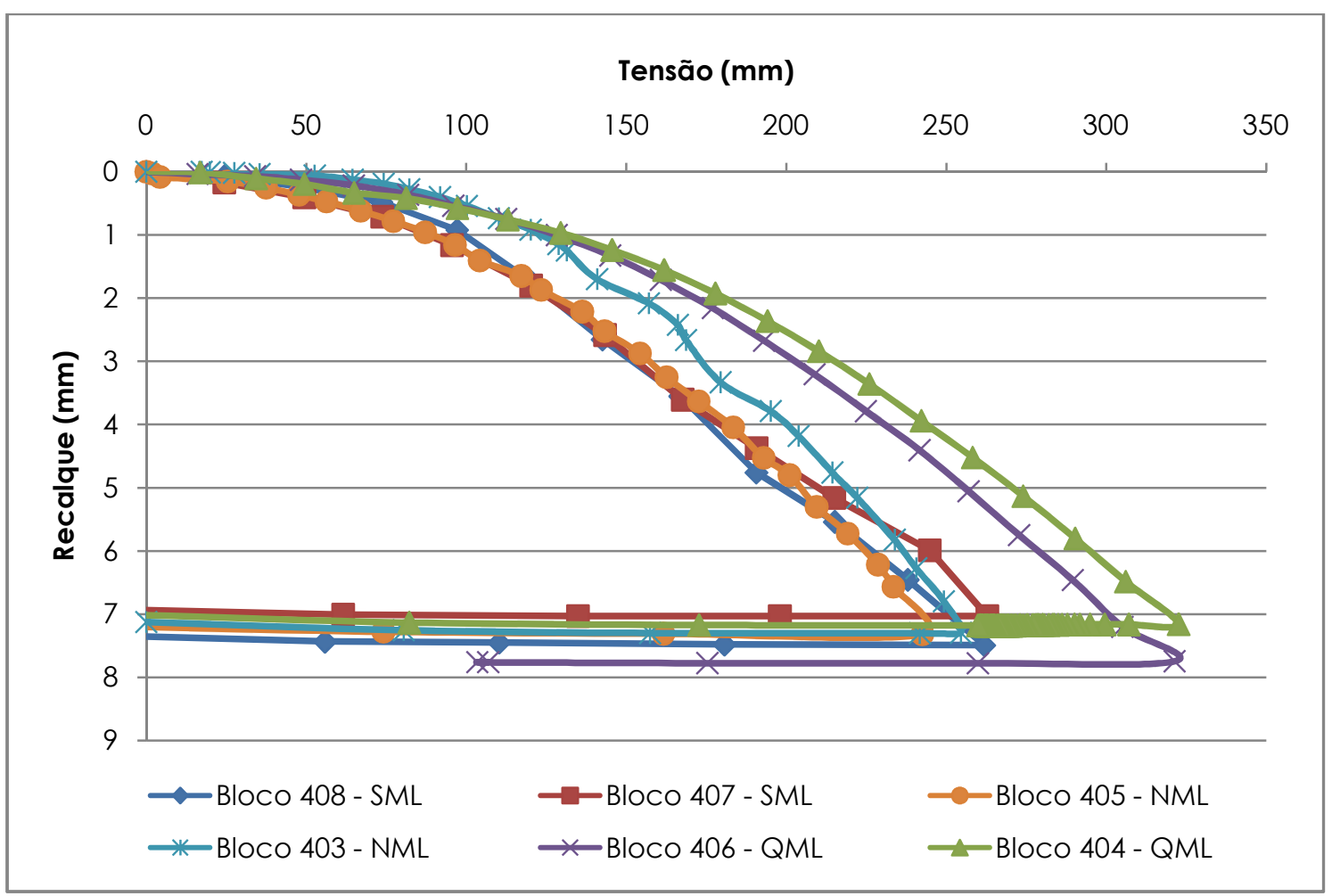

Figura 5. 14- Curvas tensão x recalque obtidas através nas de carga lenta, rápida e método do Equilíbrio $(\psi \mathrm{m}=10 \mathrm{kPa})$. 


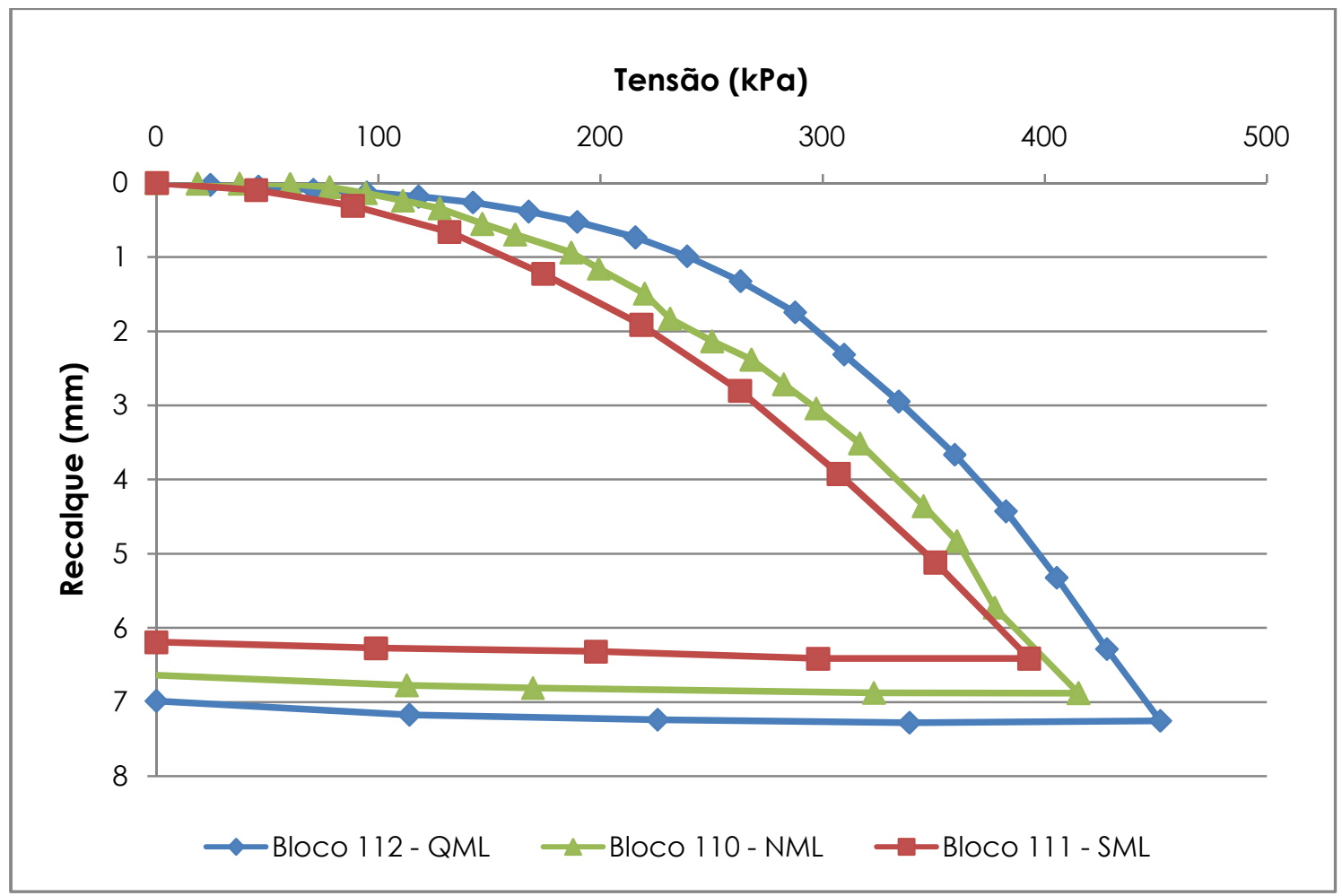

Figura 5. 15- Curvas tensão x recalque obtidas nas provas de carga lenta, rápida e método do Equilíbrio $\left(\psi_{\mathrm{m}}=35 \mathrm{kPa}\right)$.

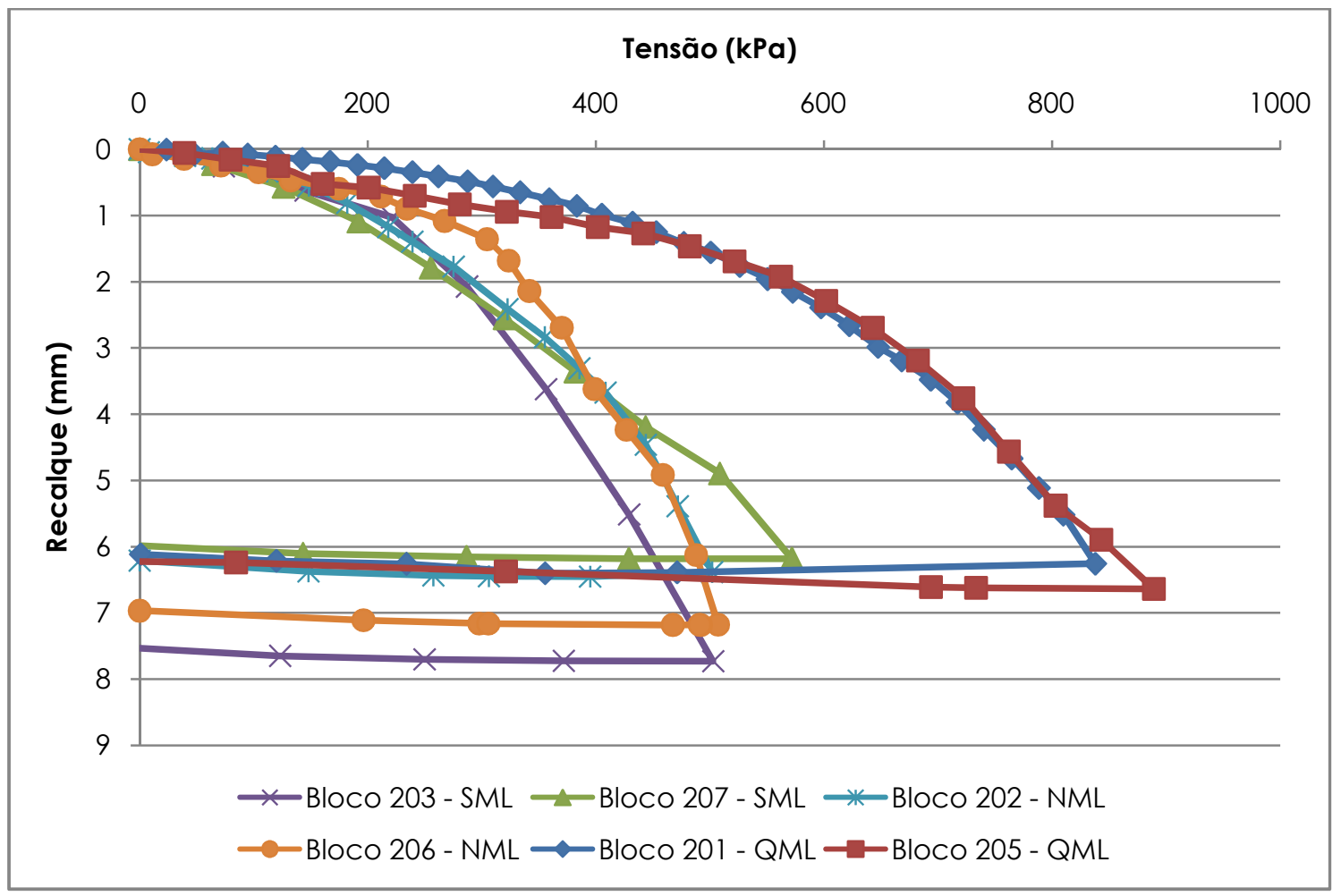

Figura 5. 16- Curvas tensão x recalque obtidas nas provas de carga lenta, rápida e método do Equilíbrio $\left(\psi_{\mathrm{m}}=45 \mathrm{kPa}\right)$. 


\subsection{Capacidade de Carga}

As curvas tensão x recalque das Figuras 5.14 a 5.16 (ensaios não-inundados) exibem uma evolução contínua da carga com o recalque, sem caracterizar a ruptura do sistema. Daí a necessidade de se empregar um critério de ruptura convencional. Adotou-se, neste trabalho, o critério de ruptura convencional de TERZAGHI (1942), pelo qual a capacidade de carga corresponde a um recalque de $10 \%$ do diâmetro da placa, neste caso um recalque de $4 \mathrm{~mm}$. O mesmo foi aplicado aos ensaios inundados.

Nas Tabelas 5.1 a 5.4 são apresentados os valores de capacidade de carga, agrupados de acordo com a sucção matricial, para os 24 ensaios realizados nesta pesquisa, além dos valores médios sempre que cabível.

Tabela 5. 1-Valores de capacidade de carga obtidos pelo critério de ruptura convencional de TERZAGHI (1942) $-\psi_{m} \cong 0$

\begin{tabular}{cccc}
\hline Ensaio & Bloco & $\sigma_{\mathbf{r}}(\mathbf{k P a})$ & Média $\sigma_{\mathbf{r}}(\mathbf{k P a})$ \\
\hline QML & 105 & 166 & \\
& 301 & 134 & 140 \\
& 305 & 120 & 61 \\
NML & 106 & 56 & \\
& 304 & 63 & \\
& 308 & 64 & 60 \\
\hline SML & 107 & 56 & \\
\hline & 306 & 60 & \\
\hline
\end{tabular}


Prova de carga rápida com recalque estabilizado

Tabela 5. 2- Valores de capacidade de carga obtidos pelo critério de ruptura convencional de TERZAGH (1942) $-\psi_{\mathrm{m}}=10 \mathrm{kPa}$

\begin{tabular}{cccc}
\hline Ensaio & Bloco & $\boldsymbol{\sigma}_{\mathbf{r}}(\mathbf{k P a})$ & Média $\boldsymbol{\sigma}_{\mathbf{r}}(\mathbf{k P a})$ \\
\hline QML & 404 & 231 & 238 \\
& 406 & 244 & 191 \\
NML & 403 & 183 & \\
\hline & 405 & 199 & 177 \\
\hline
\end{tabular}

Tabela 5. 3- Valores de capacidade de carga obtidos pelo critério de ruptura convencional de TERZAGHI (1942) $-\psi_{\mathrm{m}}=35 \mathrm{kPa}$

\begin{tabular}{ccc}
\hline Ensaio & Bloco & $\boldsymbol{\sigma}_{\mathbf{r}}(\mathbf{k P a})$ \\
\hline QML & 112 & 370 \\
\hline NML & 110 & 331 \\
\hline SML & 111 & 309 \\
\hline
\end{tabular}

Tabela 5. 4 - Valores de capacidade de carga obtidos pelo critério de ruptura convencional de TERZAGH (1942) $-\psi_{\mathrm{m}}=45 \mathrm{kPa}$

\begin{tabular}{cccc}
\hline Ensaio & Bloco & $\boldsymbol{\sigma}_{\mathbf{r}}(\mathbf{k P a})$ & Média $\sigma_{\mathbf{r}}(\mathbf{k P a})$ \\
\hline QML & 201 & 727 & 731 \\
& 205 & 735 & 438 \\
NML & 202 & 424 & \\
\hline & 206 & 452 & 400 \\
\hline
\end{tabular}


Na Figura 5.17 faz uma comparação desses valores, para quantificar a diferença porcentual da capacidade de carga nos ensaios NML e QML, em relação ao SML, para cada nível de sucção matricial.

Observa-se que a capacidade de carga obtida no ensaio NML apresenta uma variação de apenas $2 \%$ a $10 \%$ em relação ao SML, o que demonstra a validade do Método do Equilíbrio.

Já o ensaio QML apresenta variações de até $133 \%$ no valor de capacidade de carga em relação SML o que é inédito, pois em trabalhos anteriores citam diferenças da ordem de apenas $10 \%$.

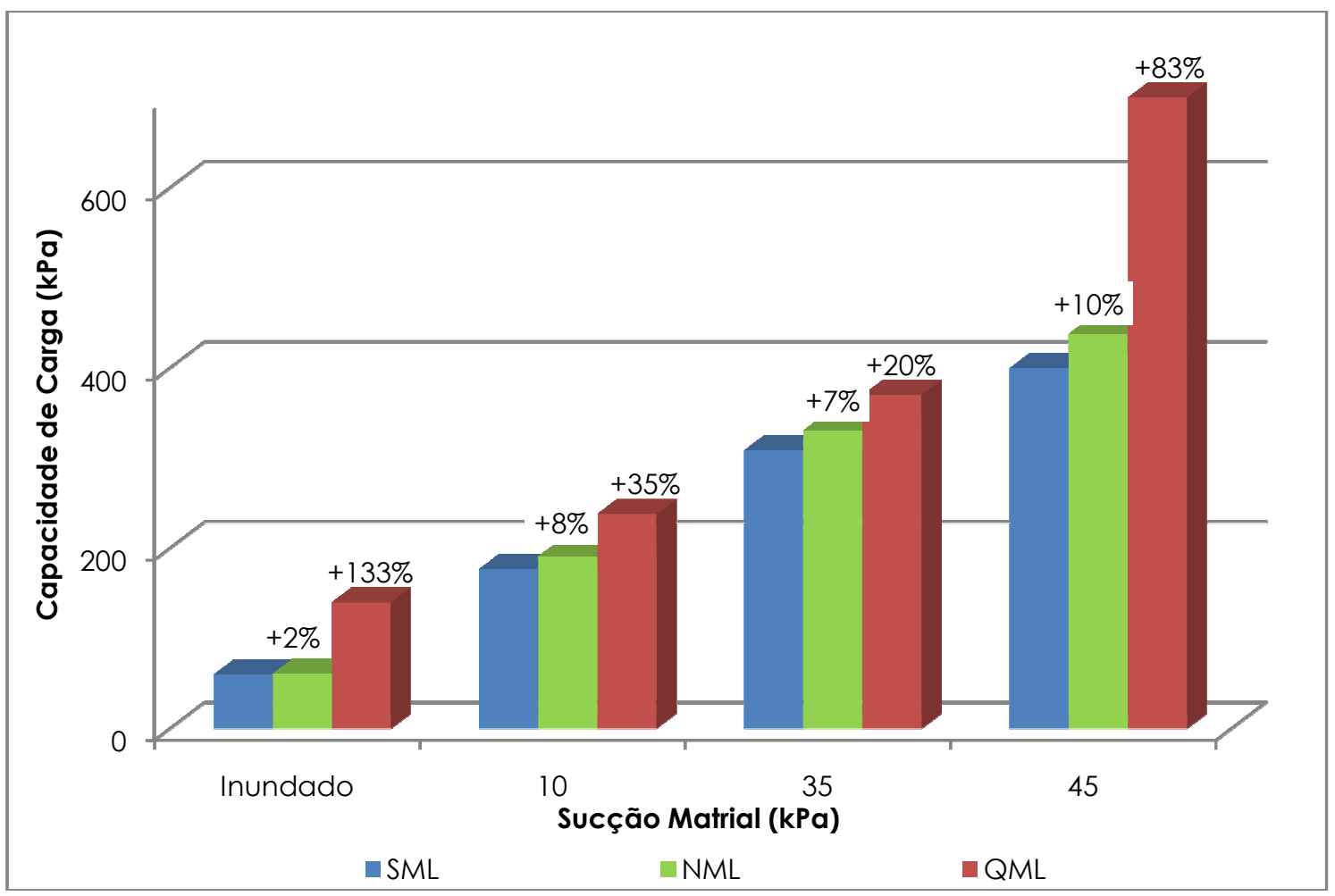

Figura 5. 17-Capacidade de carga em função da sucção e do tipo de ensaio, e variação percentual de $\sigma r$ em relação do SML

Com base nos valores médios, exceto para a sucção matricial de $\psi_{\mathrm{m}}=35 \mathrm{kPa}$, obteve-se a Figura 5.18 que mostra a tendência de variação de capacidade de carga com a sucção matricial, para cada tipo de ensaio. Pode-se constatar o resultado anômalo do ponto que representa o ensaio QML para $\psi_{\mathrm{m}}=35 \mathrm{kPa}$ 
Prova de carga rápida com recalque estabilizado

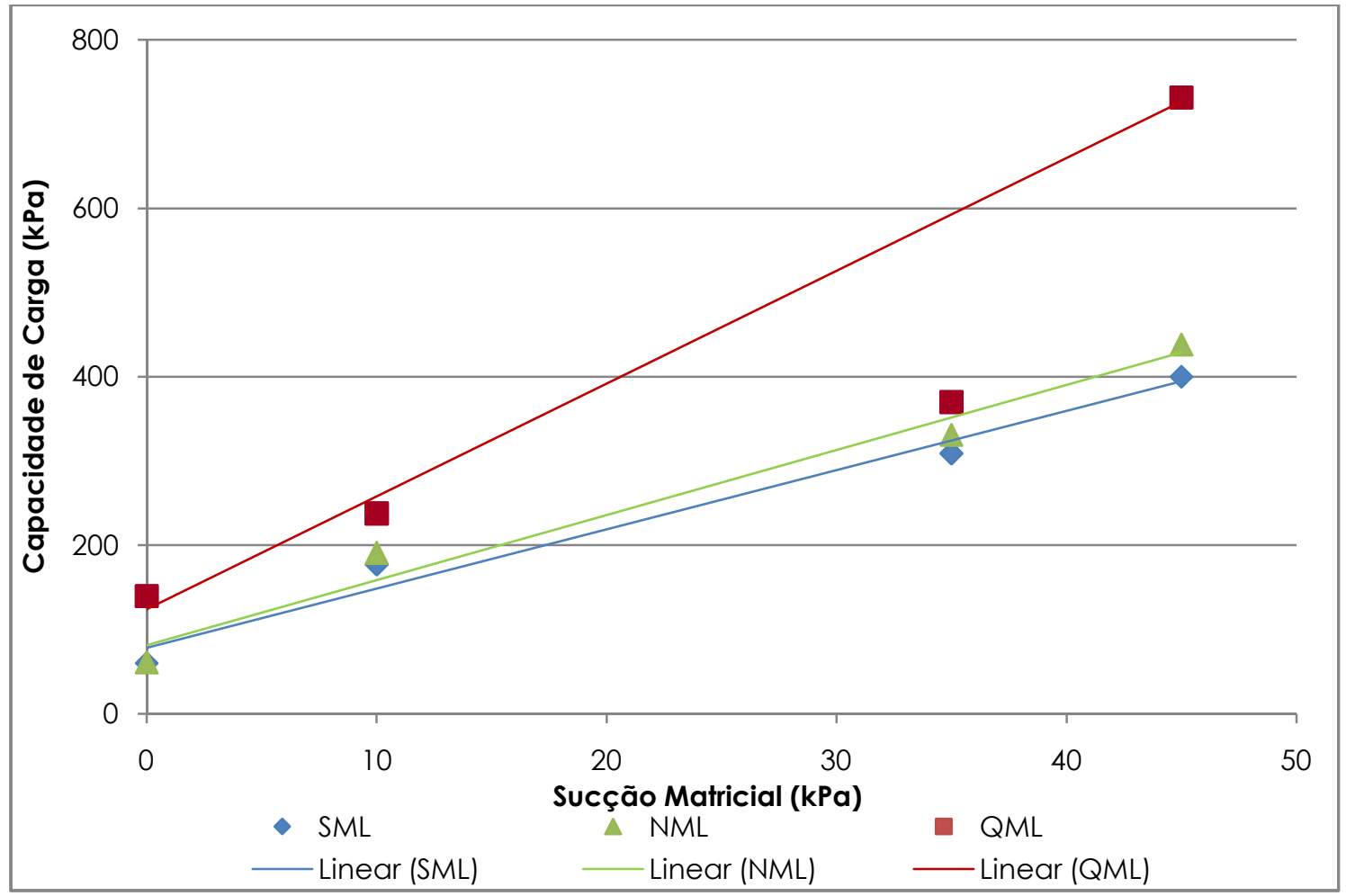

Figura 5. 18 - Variação da capacidade de carga com a sucção matricial

Através da regressão de linear de $\sigma_{\mathrm{r}}$ em função de $\psi_{\mathrm{m}}$, para cada tipo de ensaio,

com a desconsideração do ponto mencionado, foram obtidas as seguintes equações:

$\begin{array}{lll}\text { SML } & \sigma_{r}=7,0 \psi+78,6 \mathrm{kPa} & \left(\mathrm{R}^{2}=0,98\right) \\ \mathrm{NML} & \sigma_{\mathrm{r}}=7,7 \psi+81,5 \mathrm{kPa} & \left(\mathrm{R}^{2}=0,98\right) \\ & & \\ \text { QML } & \sigma_{\mathrm{r}}=13,4 \psi+124,3 \mathrm{kPa} & \left(\mathrm{R}^{2}=0,99\right)\end{array}$

Esses valores de $\mathrm{R}^{2}$ tão próximos de 1,0 confirmam a pertinência do ajuste linear entre $\sigma_{r}$ e $\psi_{m}$ já observada nos ensaios de COSTA(1999), MACACARI( 2001) e TSUHA(2003). 


\subsection{Recalque}

Para verificar a influência do tipo de ensaio nos recalques foram adotados quatro níveis de tensão correspondentes a 25\%,50\%, $75 \%$ e 100\% da capacidade de carga. Os valores encontrados de recalque, para cada sucção, são mostrados nas tabelas 5.5 e 5.8 .

Tabela 5.5 - Valores de recalque para cinco níveis de tensão $\left(\psi_{\mathrm{m}} \cong 0 \mathrm{kPa}\right)$

\begin{tabular}{|c|c|c|c|c|c|c|c|c|c|}
\hline \multirow{3}{*}{$\begin{array}{l}\text { Tensão } \\
(\mathrm{kPa})\end{array}$} & \multicolumn{9}{|c|}{ Recalque (mm) } \\
\hline & \multicolumn{3}{|c|}{ SML } & \multicolumn{3}{|c|}{ NML } & \multicolumn{3}{|c|}{ QML } \\
\hline & $\begin{array}{c}\text { Bloco } \\
107\end{array}$ & $\begin{array}{c}\text { Bloco } \\
306\end{array}$ & $\begin{array}{c}\text { Bloco } \\
307\end{array}$ & $\begin{array}{c}\text { Bloco } \\
106\end{array}$ & $\begin{array}{c}\text { Bloco } \\
304\end{array}$ & $\begin{array}{c}\text { Bloco } \\
308\end{array}$ & $\begin{array}{c}\text { Bloco } \\
105\end{array}$ & $\begin{array}{c}\text { Bloco } \\
301\end{array}$ & $\begin{array}{c}\text { Bloco } \\
305\end{array}$ \\
\hline 15 & 0,1 & 0,1 & 0,1 & 0,0 & 0,1 & 0,1 & 0,0 & 0,1 & 0,1 \\
\hline 30 & 0,3 & 0,3 & 0,2 & 0,2 & 0,5 & 0,3 & 0,1 & 0,3 & 0,1 \\
\hline 45 & 2,5 & 2,0 & 1,8 & 1,5 & 1,7 & 1,9 & 0,1 & 0,3 & 0,4 \\
\hline 60 & 4,7 & 4,1 & 3,5 & 5,0 & 3,7 & 3,6 & 0,2 & 0,5 & 0,7 \\
\hline
\end{tabular}

Tabela 5.6 - Valores de recalque para cinco níveis de tensão $\left(\psi_{\mathrm{m}}=10 \mathrm{kPa}\right)$

\begin{tabular}{|c|c|c|c|c|c|c|}
\hline \multirow{3}{*}{$\begin{array}{c}\text { Tensão } \\
\text { (kPa) }\end{array}$} & \multicolumn{6}{|c|}{ Recalque (mm) } \\
\hline & \multicolumn{2}{|c|}{ SML } & \multicolumn{2}{|c|}{ NML } & \multicolumn{2}{|c|}{ QML } \\
\hline & Bloco 407 & Bloco 408 & Bloco 403 & Bloco 405 & Bloco 404 & Bloco 406 \\
\hline 45 & 0,4 & 0,2 & 0,1 & 0,3 & 0,2 & 0,1 \\
\hline 90 & 1,0 & 0,8 & 0,4 & 1,0 & 0,5 & 0,5 \\
\hline 135 & 2,3 & 2,3 & 1,4 & 2,2 & 1,0 & 1,1 \\
\hline 180 & 4,0 & 4,2 & 3,4 & 3,9 & 2,0 & 2,3 \\
\hline
\end{tabular}


Prova de carga rápida com recalque estabilizado

Tabela 5.7 - Valores de recalque para cinco níveis de tensão $\left(\psi_{\mathrm{m}}=35 \mathrm{kPa}\right)$

\begin{tabular}{cccc}
\hline \multirow{2}{*}{$\begin{array}{c}\text { Tensão } \\
(\mathrm{kPa})\end{array}$} & \multicolumn{3}{c}{ Recalque (mm) } \\
\cline { 2 - 4 } & $\mathrm{SML}$ & $\mathrm{NML}$ & $\mathrm{QML}$ \\
\hline 80 & 0,3 & 0,1 & 0,1 \\
150 & 0,9 & 0,6 & 0,3 \\
230 & 2,1 & 1,8 & 0,9 \\
310 & 4,0 & 3,3 & 2,3 \\
\hline
\end{tabular}

Tabela 5.8 - Valores de recalque para cinco níveis de tensão $\left(\psi_{m}=45 \mathrm{kPa}\right)$

\begin{tabular}{|c|c|c|c|c|c|c|}
\hline \multirow{3}{*}{$\begin{array}{l}\text { Tensão } \\
\text { (kPa) }\end{array}$} & \multicolumn{6}{|c|}{ Recalque (mm) } \\
\hline & \multicolumn{2}{|c|}{ SML } & \multicolumn{2}{|c|}{ NML } & \multicolumn{2}{|c|}{ QML } \\
\hline & Bloco 203 & Bloco 207 & Bloco 202 & Bloco 206 & Bloco 201 & Bloco 205 \\
\hline 100 & 0,4 & 0,4 & 0,3 & 0,3 & 0,1 & 0,2 \\
\hline 200 & 0,9 & 1,2 & 1,0 & 0,7 & 0,3 & 0,6 \\
\hline 300 & 2,4 & 2,3 & 2,1 & 1,3 & 0,6 & 0,9 \\
\hline 400 & 4,8 & 3,6 & 3,6 & 3,7 & 1,0 & 1,2 \\
\hline
\end{tabular}

Para cada nível de sucção matricial, foi obtido o valor médio do recalque para cada tipo de ensaio e nível de tensão. Esses resultados são apresentados nas tabelas 5.9 a 5.12 , intercaladas pelas Figuras 5.19 a 5.22, que exibem a variação percentual do recalque para os ensaios NML e QML, em relação ao SML. 
Tabela 5.9 - Valores médios de recalque para cinco níveis de tensão ( $\psi \mathrm{m} \cong 0 \mathrm{kPa})$

\begin{tabular}{cccc}
\hline \multirow{2}{*}{$\begin{array}{c}\text { Tensão } \\
\text { (kPa) }\end{array}$} & \multicolumn{3}{c}{ Recalque médio $(\mathrm{mm})$} \\
\cline { 2 - 4 } & SML & NML & QML \\
\hline 15 & 0,1 & 0,1 & 0,1 \\
30 & 0,3 & 0,3 & 0,2 \\
45 & 2,1 & 1,7 & 0,3 \\
60 & 4,1 & 4,1 & 0,5 \\
\hline
\end{tabular}

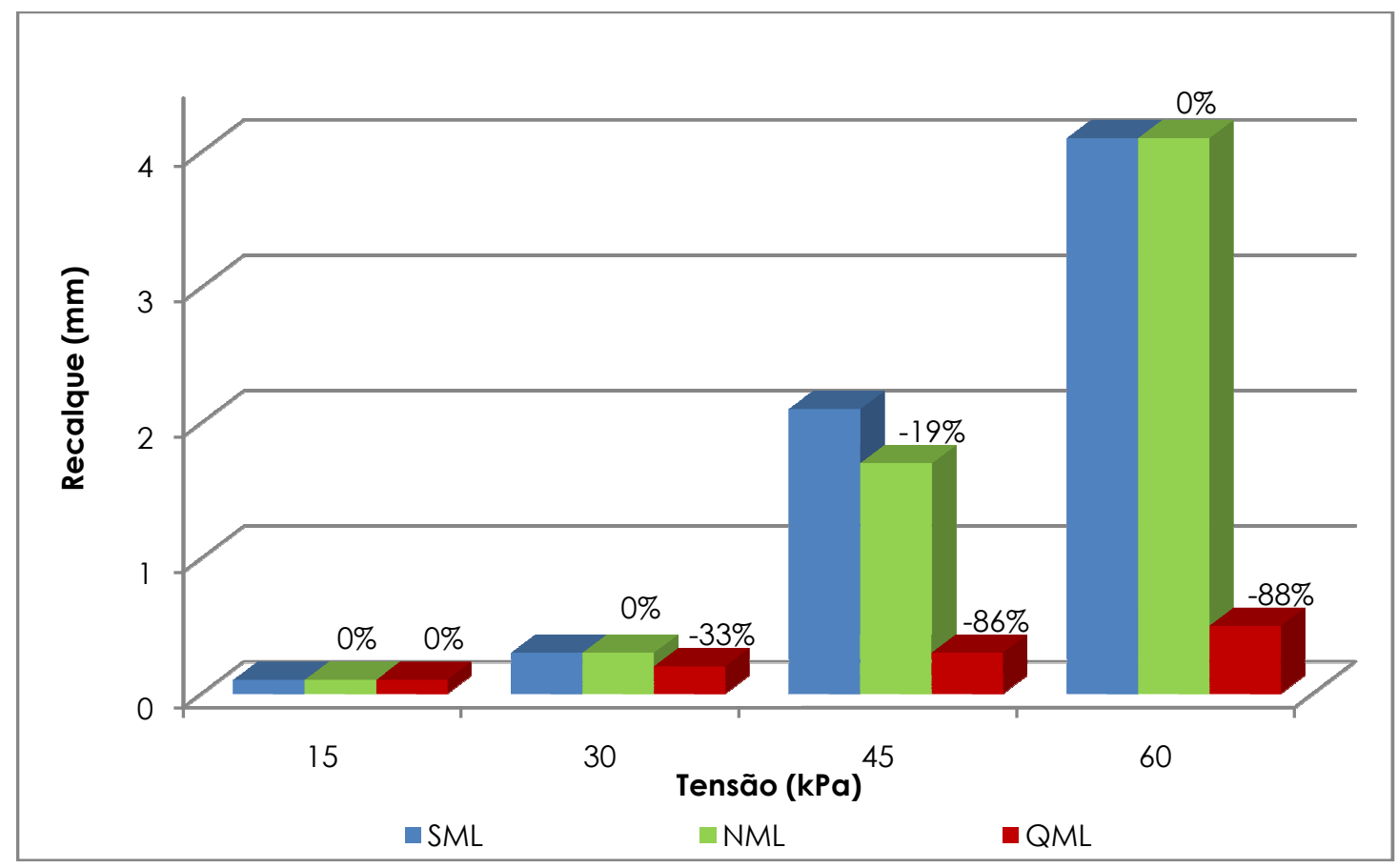

Figura 5. 19-Recalque em função da capacidade de carga e do tipo de ensaio, e variação percentual de recalque em relação do $S M L(\psi \mathrm{m} \cong 0 \mathrm{kPa})$ 
Prova de carga rápida com recalque estabilizado

Tabela 5. 10 - Valores médios de recalque para cinco níveis de tensão $\left(\psi_{\mathrm{m}}=10 \mathrm{kPa}\right)$

\begin{tabular}{cccc}
\hline & \multicolumn{3}{c}{ Recalque médio $(\mathrm{mm})$} \\
\cline { 2 - 4 } Tensão & \multicolumn{3}{c}{ (kPa) } \\
\cline { 2 - 4 } & SML & NML & QML \\
\hline 45 & 0,3 & 0,2 & 0,2 \\
90 & 0,9 & 0,7 & 0,5 \\
135 & 2,3 & 1,8 & 1,1 \\
180 & 4,1 & 3,7 & 2,2 \\
\hline
\end{tabular}

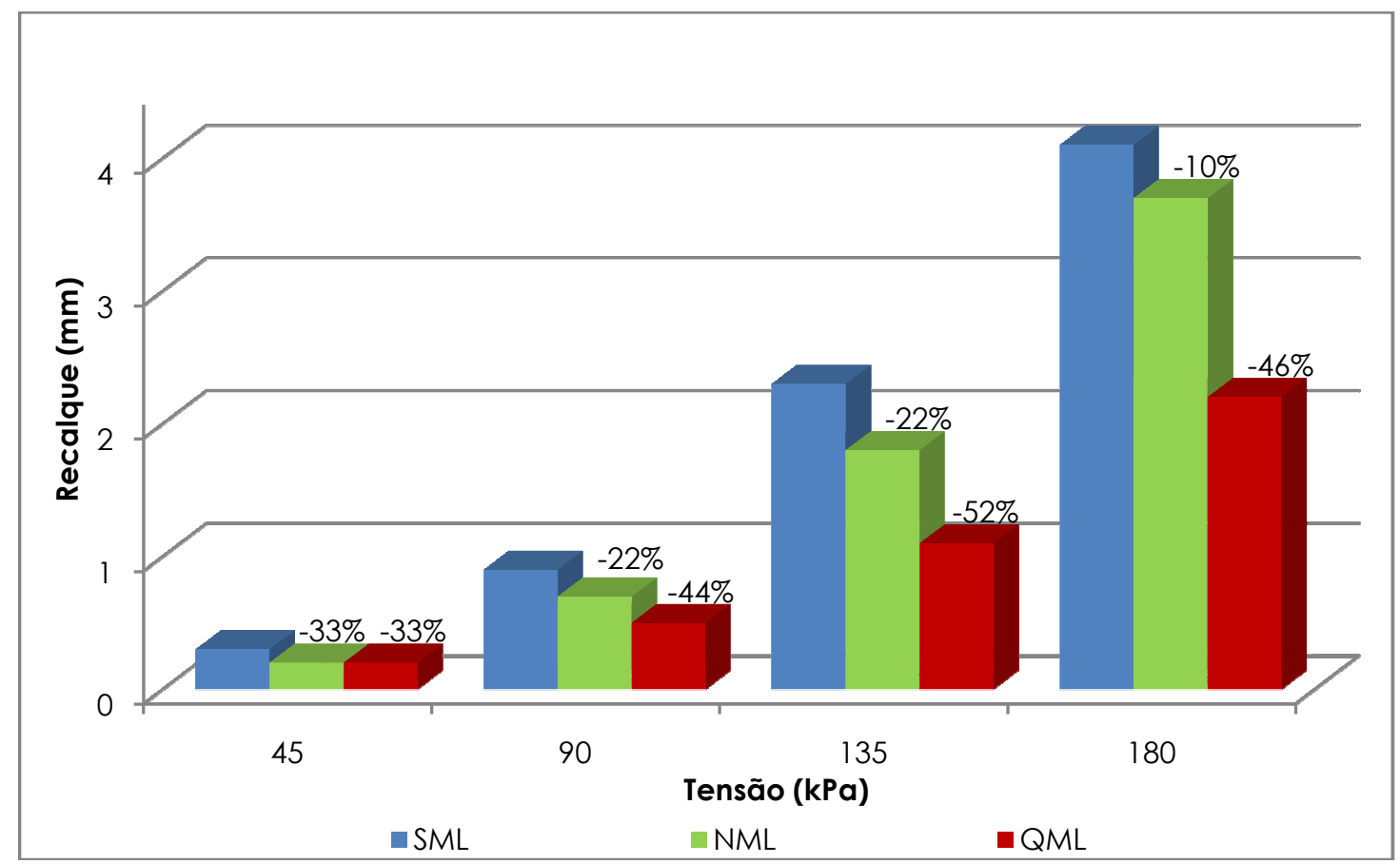

Figura 5. 20- Recalque em função da capacidade de carga e do tipo de ensaio, e variação percentual de recalque em relação do SML $\left(\psi_{\mathrm{m}}=10 \mathrm{kPa}\right)$ 
Tabela 5. 11 - Valores de médios recalque para cinco níveis de tensão $\left(\psi_{\mathrm{m}}=35\right)$

\begin{tabular}{cccc}
\hline & \multicolumn{3}{c}{ Recalque médio $(\mathrm{mm})$} \\
\cline { 2 - 4 } $\begin{array}{c}\text { Tensão } \\
\text { (kPa) }\end{array}$ & SML & NML & QML \\
\cline { 2 - 4 } 80 & 0,3 & 0,1 & 0,1 \\
150 & 0,9 & 0,6 & 0,3 \\
230 & 2,1 & 1,8 & 0,9 \\
310 & 4,0 & 3,3 & 2,3 \\
\hline
\end{tabular}

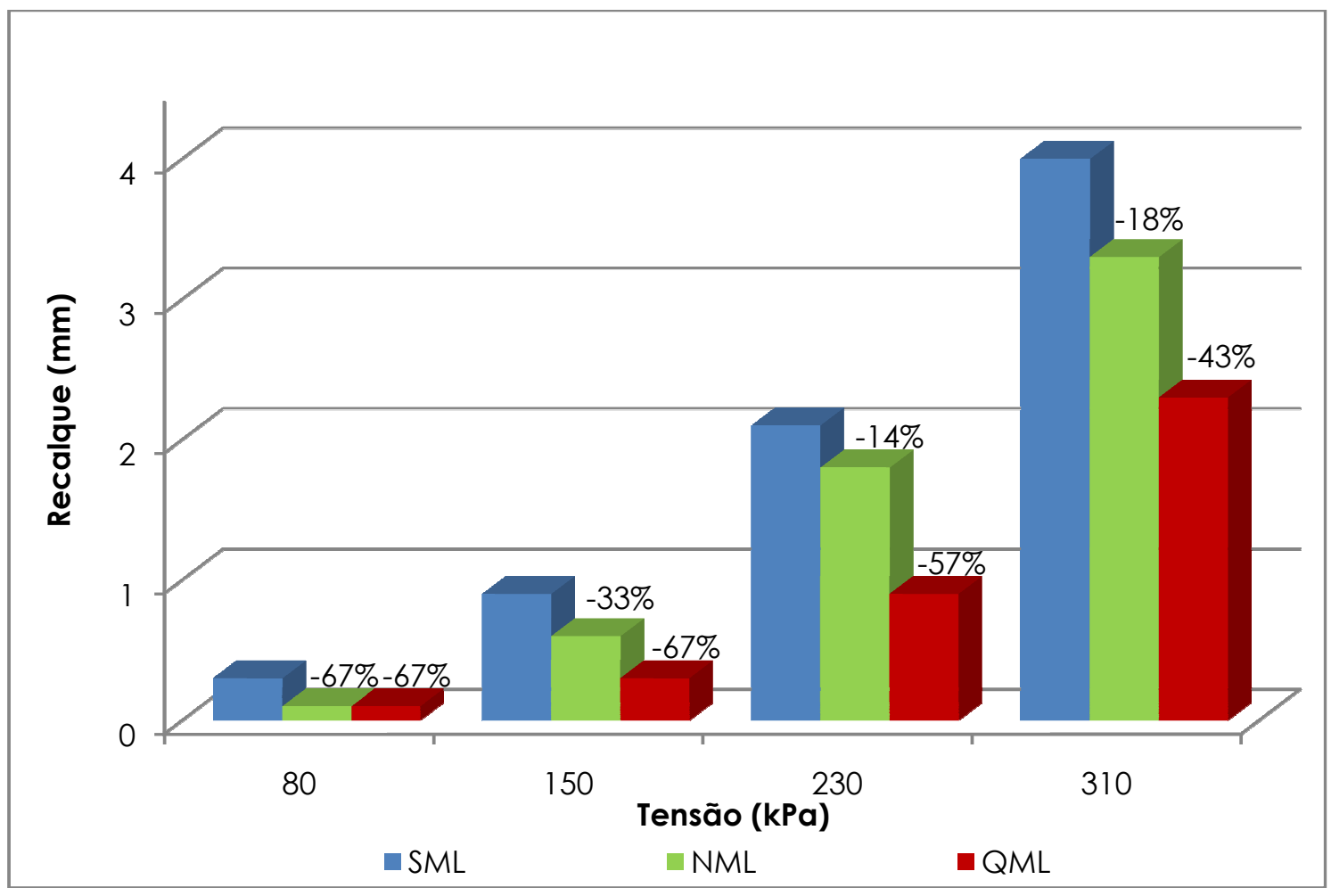

Figura 5. 21- Recalque em função da capacidade de carga e do tipo de ensaio, e variação percentual de recalque em relação do SML $\left(\psi_{\mathrm{m}}=35\right)$ 
Prova de carga rápida com recalque estabilizado

Tabela 5. 12 - Valores médios de recalque para cinco níveis de tensão $\left(\psi_{\mathrm{m}}=45\right)$

\begin{tabular}{cccc}
\hline \multirow{2}{*}{$\begin{array}{c}\text { Tensão } \\
(\mathrm{KPa})\end{array}$} & \multicolumn{3}{c}{ Recalque médio $(\mathrm{mm})$} \\
\cline { 2 - 4 } & $\mathrm{SML}$ & $\mathrm{NML}$ & $\mathrm{QML}$ \\
\hline 100 & 0,4 & 0,3 & 0,2 \\
200 & 1,1 & 0,9 & 0,5 \\
300 & 2,4 & 1,7 & 0,8 \\
400 & 4,2 & 3,7 & 1,1 \\
\hline
\end{tabular}

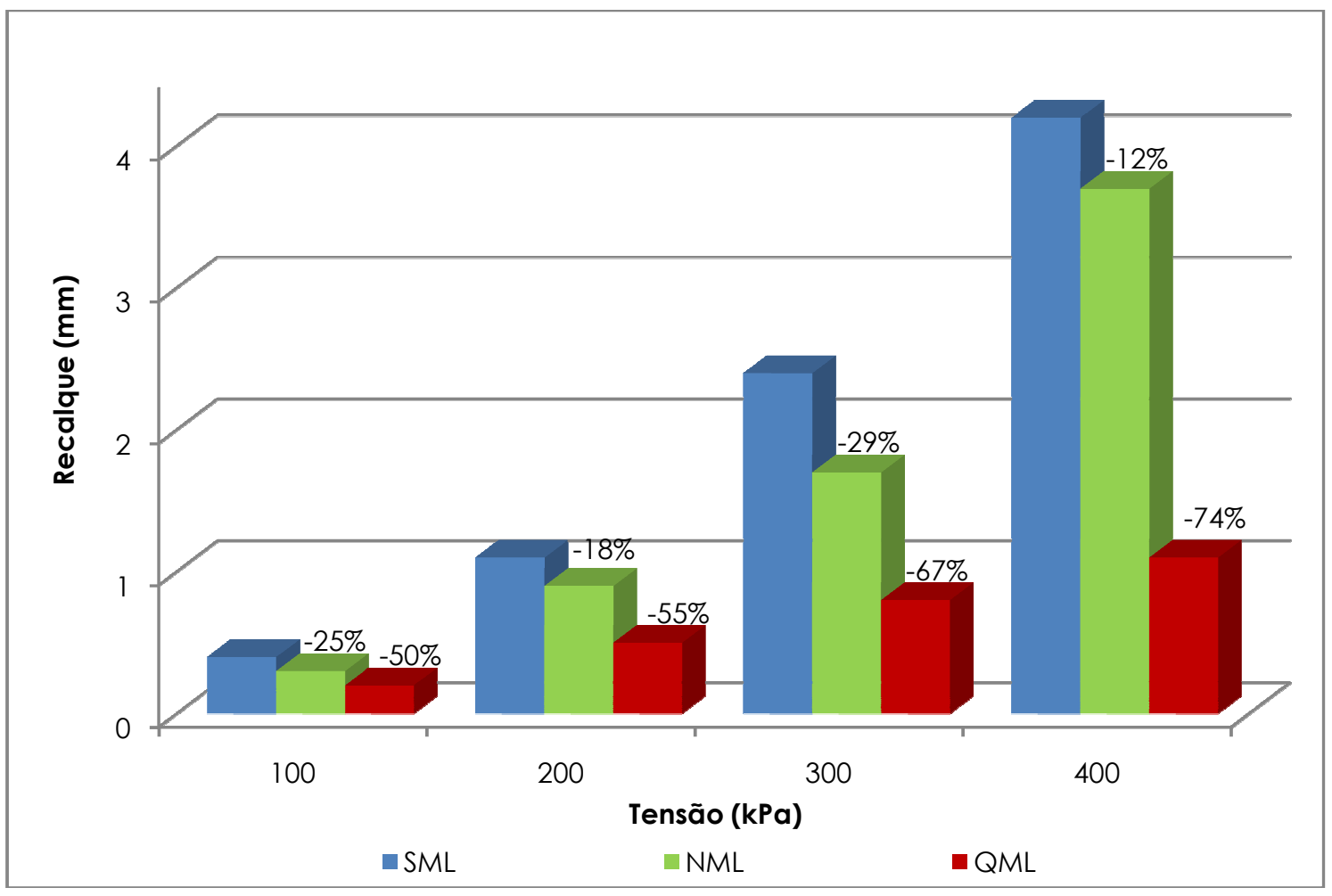

Figura 5. 22- Recalque em função da capacidade de carga e do tipo de ensaio, e variação percentual de recalque em relação do $\operatorname{SML}\left(\psi_{\mathrm{m}}=45\right)$ 
Para o primeiro nível de tensão, de $25 \%$ de capacidade de carga, todos os valores de recalque são próximos de zero (variação de 0,1 a 0,4 mm) o que torna ineficiente variação percentual.

Para os demais níveis de tensão, constata-se que todos os valores de recalque do ensaio NML apresentam uma variação de 0 a $-33 \%$ em relação ao SML, ou uma redução máxima de $1 / 3$. Já os valores de recalque do QML constituem uma variação entre $-33 \%$ e $-88 \%$, em uma relação mínima de $1 \frac{13}{3}$ em relação ao SML, o que ratifica a invalidade do QML para previsão de recalques. 
Prova de carga rápida com recalque estabilizado

\section{CONCLUSÕES}

Esta pesquisa experimental consistiu na realização de provas de carga em placa circular metálica de $40 \mathrm{~mm}$ de diâmetro, em laboratório, em blocos de solo arenoso não saturado, nas condições inundada e não inundada com controle da sucção matricial, com o objetivo de comparar três modalidades de ensaio: lento (SML), rápido (QML) e método do equilíbrio (NML). As principais conclusões obtidas são apresentadas a seguir, bem como algumas sugestões para pesquisas futuras.

A metodologia empregada mostrou-se plenamente satisfatória através da utilização inédita, para este fim, da prensa MTS-815 - Rock Mechanics Testing System do Laboratório de Mecânica das Rochas do Departamento de Geotecnia da Escola de Engenharia de São Carlos.

Considerando como referência as curvas tensão $\times$ recalque dos ensaios $S M L$, para cada condição de ensaio, as curvas do NML são bem próximas do SML, enquanto as do QML são muito distantes, bem mais do que se poderia supor.

Em conseqüência, os valores de capacidade de carga do QML são muito maiores que os do SML, no mínimo $20 \%$ e chegando até $133 \%$ a mais. Já no NML, a capacidade de carga é de no máximo $10 \%$ acima da obtida no SML, para a mesma condição de ensaio.

Ademais, ratifica-se o importante papel da sucção matricial no aumento da capacidade de carga. Os dados obtidos confirmam a pertinência do ajuste linear entre capacidade de carga e sucção matricial, já observada em outros trabalhos.

Em termos de recalque, para níveis de tensão de pelo menos a metade da capacidade de carga, para cada condição de ensaio, os valores obtidos pelo NML são relativamente próximos dos valores do SML, com diferença máxima de 33\% para menos, considerando todas condições de ensaio.

Já os valores de recalque do QML são bem mais discrepantes, representando uma variação mínima de -33\% em relação ao SML, chegando até a -88\%. A literatura já apontava a inadequação do QML para análises de recalques, mas as diferenças encontradas nesta pesquisa agravam essa consideração. 
Tanto do ponto de vista de capacidade de carga como de recalques, o método do equilíbrio parece, portanto, constituir uma alternativa promissora, pois pode aliar as vantagens do ensaio lento e do rápido, ao obter recalques estabilizados em curto período de tempo.

A modificação implementada na execução do ensaio pelo método do equilíbrio, ao fixar o tempo do estágio em 15 min, constitui um aprimoramento do ensaio, pois passou a ser possível prever a sua duração e também viabilizar a sua realização dentro do período útil de um dia. O fato de fixar a duração do estágio não comprometeu a determinação do valor estabilizado de carga, pois com a série de pontos tensão x recalque obtidos em cada estágio mostra uma variação exponencial decrescente, caracterizando uma assíntota correspondente ao valor estabilizado de carga.

Devido ao caráter promissor do método do equilíbrio, constatado nesta pesquisa, desenvolvida através de provas de carga em modelo, incentiva-se a continuidade de trabalhos experimentais para um melhor desenvolvimento desta modalidade de ensaio.

O próximo passo, obviamente, é realização de ensaios de placa in situ e em estacas para comparação sobretudo do NML com o SML.

Além disso, sugere-se a redução 20 para 10 estágios no NML, mas com duração de 30 min cada, em vez de 15 min. Assim, com a mesma duração de $5 \mathrm{~h}$ para o carregamento, pode-se utilizar um tempo maior, de até $15 \mathrm{~min}$, para a fase de carga mantida, em cada estágio. 
Prova de carga rápida com recalque estabilizado

\section{REFERÊNCIAS BIBLIOGRÁFICAS}

AOKI, N. (1989). A new dynamic load test concept. In: XII INTERNACIONAL CONFERENCE ON SOIL MECHANICS AND FOUNDATION ENGINEERING. TC Pile Driving. Rio de Janeiro.

ASSOCIAÇÃO BRASILEIRA DE NORMAS TÉCNICAS - ABNT (1984). NBR 6489: Prova de Carga Direta sobre Terreno de Fundação. Rio de Janeiro.

ASSOCIAÇÃO BRASILEIRA DE NORMAS TÉCNICAS - ABNT (1986). NBR 6121: Estaca e tubulão Prova de Carga. Rio de Janeiro.

ASSOCIAÇÃO BRASILEIRA DE NORMAS TÉCNICAS - ABNT (1991). NBR 13208: Estacas - Ensaio de Carregamento Dinâmico. Rio de Janeiro.

ALONSO, U.R. (1977). Prova de carga estática em estacas (uma proposta para revisão da norma NBR 12131). Solos e Rochas, v. 20, no 1.

BENVENUTTI, M. (2001). Cravação de tubulões à céu aberto para melhoria na capacidade de carga em solos colapsíveis. Dissertação de Mestrado. Escola de Engenharia de São Carlos. Universidade de São Paulo.

CINTRA, J.C.A (1995). Fundações em solos colapsíveis. Texto de Livre-docência. Escola de Engenharia de São Carlos, Universidade de São Paulo.

CINTRA, J.C.A (1998). Fundações em solos colapsíveis. São Carlos, Serviço Gráfico da Escola de Engenharia de São Carlos, Universidade de São Paulo.

CINTRA, J.C.A.; AOKI, N.; ALBIERO, J.H. (2003). Tensão admissivel em fundações diretas. São Carlos: RiMa.

CINTRA, J.C.A.; BENVENUTTI, M.; AOKI, N.(2004a). Tubulões cravados em solo colapsível. In: $5^{\circ}$. Simpósio Brasileiro sobre solos não saturados. São Carlos, v.1, p. 333-337.

CINTRA, J.C.A.; (2004b). Aplicações da mecânica dos solos não-saturados - Fundações em Solos Colapsíveis. In; $5^{\circ}$. Simposio Brasileiro de solos não-saturados. São Carlos, vol. 2, p. 575593.

COELHO, S. L.; TEIXEIRA, A.S. (2004). Avaliação de tensiômetro eletrônico no monitoramento do potencial matricial de água no solo. Engenharia Agrícola. Jaboticabal, v.24, no. 3, p. 536545. 
CONCIANI, W. (1997). Estudo do colapso do solo através de ensaios de placa monitorados com tensiometros e tomografia computadorizada. Teste de Doutorado. Escola de Engenharia de São Carlos. Universidade de São Paulo.

COSTA, Y.D.J. (1999). Estudo do comportamento de solo não saturado através de provas de carga em placa. Dissertação de Mestrado. Escola de Engenharia de São Carlos. Universidade de São Paulo.

COSTA, Y.D.J; MENEGOTTO, M.L.; CINTRA, J.C.A. (2000). In: SEMINÁRIO DE ENGENHARIA DE FUNDAÇÕES ESPECIAIS. São Paulo. Anais, v.2, p. 225-235.

DE MELLO, V.F.B. (1975). Deformações como base fundamental de escolha da fundação. Geotecnia. Lisboa, no. 12.

DÉCOURT, L.; QUARESMA, A. R. F. (1996). Estabelecimento das curvas carga x recalque de fundações através de provas de carga em mini-placa. In: SEMINÁRIO DE ENGENHARIA DE FUNDAÇÕES ESPECIAIS. São Paulo. Anais, v.2, p. 225-235.

FELLENIUS, B.H. (1975). Test loading of piles and new proof testing procedure. ASCE, Journal of Geotechnical Engeneering Division, v. 101, n. GT-9, September, 1975, p. 855-69.

FELLENIUS, B.H. (1980). The analysis of results from routine pile load tests. GROUND ENGENEERING DIVISION. Foundation, v. 13, n. 16, September, 1980, p.19-31.

FERREIRA, A.C. (1985). Efeito do tempo de carregamento e a questão dos recalques de estacas em provas de carga. Dissertação de Mestrado - COPPE, URFJ, Rio de Janeiro.

FERREIRA, A.C. (198x). Contribuição ao estudo do efeito do tempo de carregamento no comportamento de estacas de prova. In: SEMINÁRIO DE ENGENHARIA DE FUNDAÇÕES ESPECIAIS. São Paulo. Anais, v.x, p. 185-192.

FRANCISCO, G.M. (2004). Estudo dos efeitos do tempo em estacas de fundação em solos argilosos. Tese de Doutorado - COPPE, UFRJ, Rio de Janeiro.

FREDLUND, D.G.; RAHARDJO, H. (1993). Soil mechanics for unsaturated soils. New York, John Wiley \& Sons.

HOUSEL, W.S. (1966). Pile load capacity. Estimates and test results. Proc. ASCE, vol. 92, SM4.

IPT (1944). Estudo das Fundações dos hangares da Escola Aeronática de Pirassununga. São Paulo, Relatório no. 676, 10/5/1944.

IPT (1954). Estudo das fundações para as futuras instalações da Escola de Engenharia de São Carlos. São Paulo, Relatório no. 2269, 10/09/1954. 
Prova de carga rápida com recalque estabilizado

IPT (1988). Provas de carga em fundação. São Paulo.

JENNINGS, J.E. \& KNIGHT, K. (1975). A guide to construction on or with materials exhibiting additional settlement due to collapse of grain structure. In: VII REGIONAL CONFERENCE FOR AFRICA ON SOIL MECHANICS AND FOUNDATION ENGINEERING. Durban, v. 1, p 99-105.

MACACARI, M.F. (2001). Variação da capacidade de carga com a sucção e profundidade em ensaios de placa em solos colapsível. Dissertação de Mestrado. Escola de Engenharia de São Carlos. Universidade de São Paulo.

MACEDO, A.; VAZ, C.M.P.; BASSOI, L.H., HOPMANS, J.W.; (2000). Calibração e uso de uma sonda combinada tensiômetro/TDR. In: COMUNICADO TÉCNICO. São Carlos, Embrapa.

MENEGOTTO, M.L. (2004). Previsão da curva tensão x recalque de ensaios de placa em solos não saturado. Tese de Doutorado. Escola de Engenharia de São Carlos. Universidade de São Paulo.

MOHAN, D., JAIN, G.S., JAIN, N.P. (1967). A new approach to load tests. Geotechinique, London, v. 17.

NIYAMA, S.; AOKI, N. (1991). Correlação entre provas de Carga Dinâmica no campo experimental da EPUSP/ABEF. In: SEMINÁRIO DE ENGENHARIA DE FUNDAÇÕES ESPECIAIS. São Paulo. Anais, v.1, p. 285-293.

SBRT - Serviço Brasileiro de Respostas Técnicas. Disponível http://www.sbrt.ibict.br. Acesso em 13/10/2008.

SOCCOL et al. (2005). Conditância hidráulica e tempo de resposta de tensiômetros utilizados em cultivos fertirrigados. In: Revista de Ciência Agroveterinárias. Lages, v.4, n.1, p. 3-10.

SACILOTTO, A.C. (1992). Comportamento de estacas escavadas instrumentadas, submetidas a provas de carga lentas e rápidas. Dissertação de mestrado. Escola de Engenharia de São Carlos. Universidade de São Paulo.

SOTO, M.A.A. (2004). Comparação entre métodos de imposição de sucção em ensaios com solos não saturados. Tese de Doutorado Escola de Engenharia de São Carlos. Universidade de São Paulo.

SOUZA, A. (1993). Utilização de fundações rasas no solo colapsível de llha Solteira. Dissertação de Mestrado. Escola de Engenharia de São Carlos. Universidade de São Paulo.

TEIXEIRA, A. H.; GODOY, N.S. (1998). Análise, projeto e execução de fundações rasas. In: HACHICH et al. (eds.) Fundações: teoria e prática. 2 ed. São Paulo. PINI. Cap. 7, p. 227 a 264. 
TERZAGHI, K. (1942). Discussion on pile formulas. ASCE, 68(2). p. 31 1-323.

TERZAGHI, K. (1943). Teorical Soil Mechanics. New York, Jonh Willey \& Sons.

TSUHA, C.H.C. (2003). Utilização de Penetrômetro manual em solos colapsível e comparacao com resultados de provas de carga em placa e em sapata. Dissertação de Mestrado. Escola de Engenharia de São Carlos. Universidade de São Paulo.

VARGAS, M. (1990). Provas de carga em estacas - Uma apreciação histórica. Revista solos e Rochas. São Paulo, v.13, p. 3-12.

VELLOSO D.A.; LOPES, F.R. (1996). Fundações - Volume 1. Rio de Janeiro. COPPE-URFJ.

VELLOSO D.A.; LOPES, F.R. (2002). Fundações - Volume 2. Rio de Janeiro. COPPE-URFJ.

VIANNA, A.P.F. (2005). Influência da dimensão e da sucção matricial no comportamento de fundações superficiais assente em solo arenoso não-saturado. Tese de doutorado. Escola de Engenharia de São Carlos. Universidade de São Paulo.

WHITAKER, T. (1957). Experiments with model piles in groups. Geotechnique, Vol. 7, no. 4, p. 147-167.

WHITAKER, T.; COOKE, R.W. (1961). A new approach to pile testing. In: ICSMFE, 5. Paris, v.2, p. $171-176$

WHITAKER, T. (1970). The design of piled foundations", Pergamon Press Limited, $1^{a}$ Ed., Oxford.

WINZ, H.C. (1999). Provas de carga estáticas, lentas e rápidas, e dinâmicas em estacas. Dissertação de Mestrado. Universidade de São Paulo, São Paulo.

WOLLE \& CARVALHO (1988) -Medidas in situ de tensões de seccão. In: SIMPÓSIO SOBRE NOVOS CONCEITOS EM ENSAIOS DE CAMPO E LABORATÓRIO EM GEOTECNIA., Rio de Janeiro, COPPE UFRJ, v. 1 p. 645-665. 